\title{
Description of Piezometers Installed in the Middle Rio Grande Basin Area in and near Albuquerque, New Mexico, 1996-2001
}

U.S. DEPARTMENT OF THE INTERIOR U.S. GEOLOGICAL SURVEY

Open-File Report 03-290

Prepared in cooperation with the

CITY OF ALBUQUERQUE and

BERNALILLO COUNTY

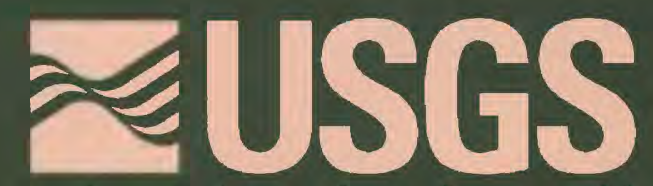
science for a changing world 



\section{Description of Piezometers Installed in the Middle Rio Grande Basin Area in and near Albuquerque, New Mexico, 1996-2001}

By Lisa C. Donohoe and Stephanie J. Moore

U.S. GEOLOGICAL SURVEY

Open-File Report 03-290

Prepared in cooperation with the

CITY OF ALBUQUERQUE and

BERNALILLO COUNTY 


\title{
U.S. DEPARTMENT OF THE INTERIOR \\ GALE A. NORTON, Secretary
}

\author{
U.S. GEOLOGICAL SURVEY
}

Charles G. Groat, Director

The use of firm, trade, and brand names in this report is for identification purposes only and does not constitute endorsement by the U.S. Geological Survey.

For additional information write to:

District Chief

U.S. Geological Survey

Water Resources Division

5338 Montgomery Blvd. NE, Suite 400

Albuquerque, NM 87109-1311
Copies of this report can be purchased from:

U.S. Geological Survey

Information Services

Box 25286

Denver, CO 80225-0286

Information regarding research and data-collection programs of the U.S. Geological Survey is available on the Internet via the World Wide Web. You may connect to the home page for the New Mexico District Office using the URL $h t t p: / / n m$.water.usgs.gov. 


\section{CONTENTS}

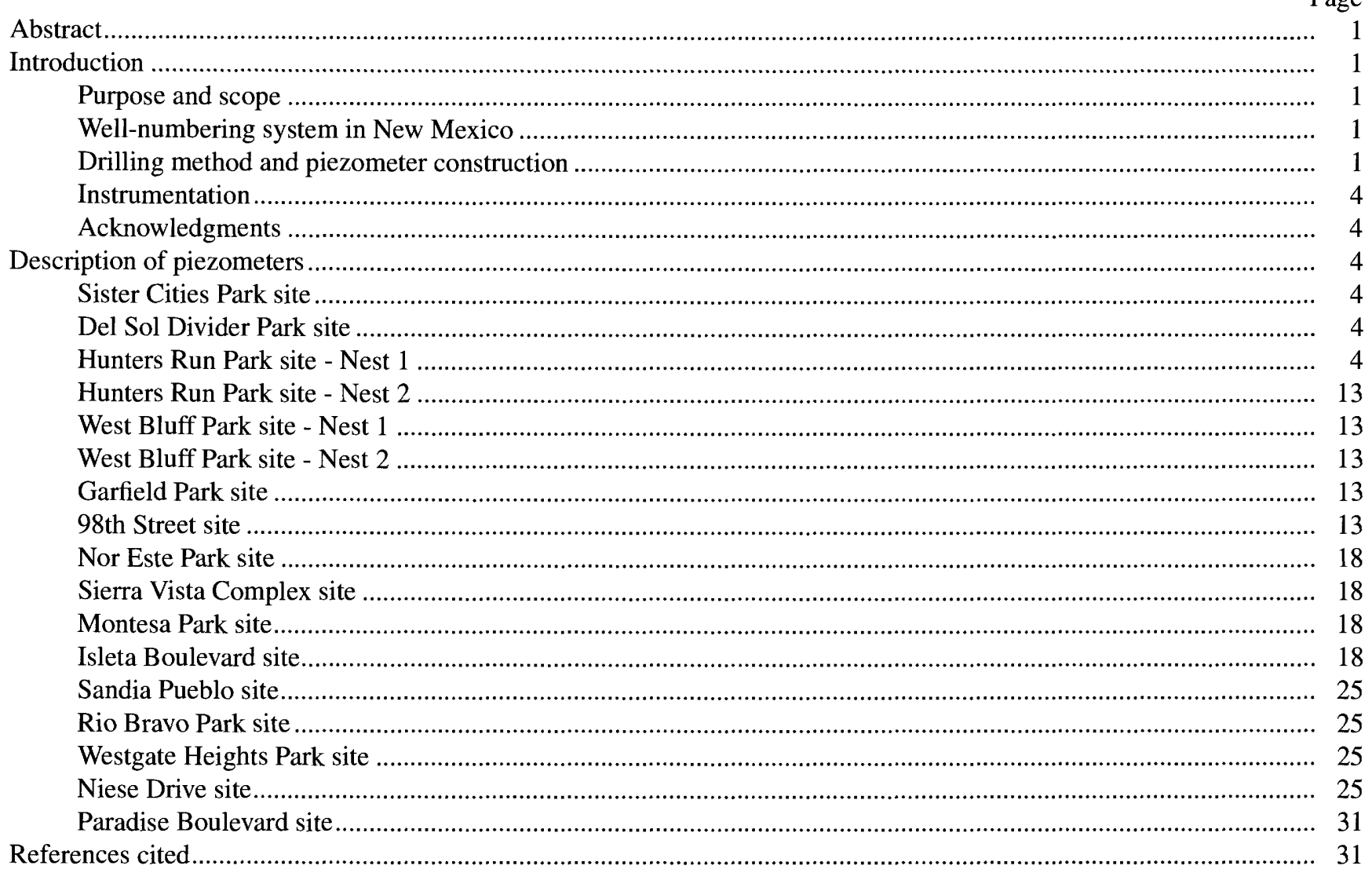

\section{FIGURES}

1. Map showing location of piezometer sites in the metropolitan area of Albuquerque, New Mexico ..................... 2

2. Diagram showing system of numbering wells in New Mexico used to designate piezometer sites in this report .

3. Map showing location of the Sister Cities Park piezometer site

4. Diagrams showing configuration of the piezometers at the Sister Cities Park, Del Sol Divider Park, and Hunters Run Park sites

\section{5-7. Maps showing}

5. Location of the Del Sol Divider Park piezometer site ..................................................................... 11

6. Location of the Hunters Run Park piezometer site ............................................................................ 12

7. Location of the West Bluff Park piezometer site .............................................................................. 14

8. Diagrams showing configuration of the piezometers at the West Bluff Park, Garfield Park, and 98th Street sites. . . .

9-11. Maps showing:

9. Location of the Garfield Park piezometer site ….............................................................................. 16

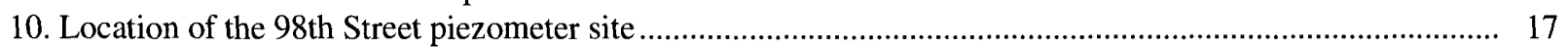

11. Location of the Nor Este Park piezometer site ..................................................................................... 19

12. Diagrams showing configuration of the piezometers at the Nor Este Park, Sierra Vista Complex, and Montesa Park sites. 
13-15. Maps showing:

13. Location of the Sierra Vista Complex piezometer site ............................................................................ 21

14. Location of the Montesa Park piezometer site ....................................................................................... 22

15. Location of the Isleta Boulevard piezometer site................................................................................. 23

16. Diagrams showing configuration of the piezometers at the Isleta Boulevard, Sandia Pueblo, and Rio Bravo Park sites

17-19. Maps showing:

17. Location of the Sandia Pueblo piezometer site

18. Location of the Rio Bravo Park piezometer site

19. Location of the Westgate Heights Park piezometer site.

20. Diagrams showing configuration of the piezometers at the Westgate Heights Park, Niese Drive, and Paradise Boulevard sites

21. Map showing location of the Niese Drive piezometer site.

22. Map showing location of the Paradise Boulevard piezometer site.

23. Geophysical logs, piezometer completions, and generalized lithologic diagrams for the:
A. Sister Cities Park site
B. Del Sol Divider Park site.
C. Hunters Run Park site
D. West Bluff Park site..
E. Garfield Park site.
F. 98th Street site.
G. Nor Este Park site
H. Sierra Vista Complex site.
46
I. Montesa Park site 48
J. Isleta Boulevard site. 50
K. Sandia Pueblo site.
L. Rio Bravo Park site
M. Westgate Heights Park site.
N. Niese Drive site.
O. Paradise Boulevard site.
52
54
56
58
60
62

\section{TABLE}

1. Site and construction information and water-level data for piezometers installed in the Middle Rio Grande Basin area by the U.S. Geological Survey.....

\section{CONVERSION FACTORS AND DATUMS}

\begin{tabular}{rcll}
\hline Multiply & \multicolumn{1}{c}{ By } & To obtain \\
\hline inch & 2.540 & centimeter \\
inch & 25.4 & millimeter \\
foot & 0.3048 & meter \\
mile & 1.609 & kilometer \\
acre & 4,047 & square meter \\
\hline
\end{tabular}

Vertical coordinate information is referenced to the National Geodetic Vertical Datum of 1929 (NGVD 29).

Horizontal coordinate information is referenced to the North American Datum of 1927 (NAD 27). 


\title{
DESCRIPTION OF PIEZOMETERS INSTALLED IN THE MIDDLE RIO GRANDE BASIN AREA IN AND NEAR ALBUQUERQUE, NEW MEXICO, 1996-2001
}

\author{
By Lisa C. Donohoe and Stephanie J. Moore
}

\section{ABSTRACT}

From March 1996 to April 2001, 50 piezometers were installed at 15 sites in and near Albuquerque, New Mexico, by the U.S. Geological Survey in cooperation with the City of Albuquerque and Bernalillo County. The drilling is part of a program to improve the understanding of the Santa Fe Group aquifer system in the Middle Rio Grande Basin.

The U.S. Geological Survey drilled the boreholes using mud-rotary drilling. Geophysical logs were collected at each site. The lithology was described in detail from drill cuttings at each site.

Most piezometers are located at least 1 mile from production wells to minimize the effects of municipal pumping. Piezometer screens are located to allow for collection of water-level and water-quality data at discrete intervals in the aquifer. All the piezometers are instrumented with a differential-pressure transducer to measure ground-water levels. Each site is equipped with a multichannel, electronic data logger that records hourly ground-water levels in each piezometer.

\section{INTRODUCTION}

In July 1995, the U.S. Geological Survey (USGS), in cooperation with the City of Albuquerque and Bernalillo County, began a program to install a network of monitoring piezometers to improve the understanding of the Santa Fe Group aquifer system in the Middle Rio Grande Basin, particularly in the Albuquerque area. The program is designed for waterlevel and water-quality data to be collected at discrete intervals in the aquifer. Most piezometers are located at least 1 mile from production wells to minimize the effects of municipal pumping.

\section{Purpose and Scope}

This report describes the location and construction of 50 piezometers at 15 sites drilled by the USGS in the Middle Rio Grande Basin area in and near Albuquerque in central New Mexico (fig. 1). Included are geophysical logs, piezometer completion diagrams, lithologic diagrams, piezometer configuration diagrams, water-level data, and piezometer location information. The piezometers were installed from March 1996 to April 2001.

\section{Well-Numbering System in New Mexico}

The system of numbering wells in New Mexico is used to designate the location of piezometer sites in this report. The system is based on the common subdivision of public lands into sections (fig. 2). The well number, in addition to designating the well, locates its position to the nearest 10 -acre tract in the land network. This number is divided into four segments. The first segment denotes the township north (N.) or south (S.) of the New Mexico base line, the second denotes the range east (E.) or west (W.) of the New Mexico principal meridian, and the third denotes the section. The fourth segment (the section) of the number consists of three digits and denotes the 160-, 40 -, and 10-acre tracts, respectively. The section is divided into four quarters, numbered $1,2,3$, and 4 , in the normal reading order, for the northwest, northeast, southwest, and southeast quarters. The first digit of the fourth segment denotes the quarter section, which is a tract of 160 acres. Similarly, the quarter section is divided into four 40 -acre tracts numbered in the same manner, and the second digit denotes the 40-acre tract. Finally, the 40 -acre tract is divided into four 10 -acre tracts, and the third digit denotes the 10 -acre tract. For example, piezometer site 09N.02E.28.312 is in the NE $1 / 4$ of the NW $1 / 4$ of the SW $1 / 4$ of section 28, T. 09 N., R. 02 E. Letters A, B, C, and so on are added to the fourth segment to designate the second, third, fourth, and succeeding piezometers in the same 10 -acre tract.

\section{Drilling Method and Piezometer Construction}

A crew from the USGS Central Region Drilling Project, under the direction of a USGS hydrologist, 


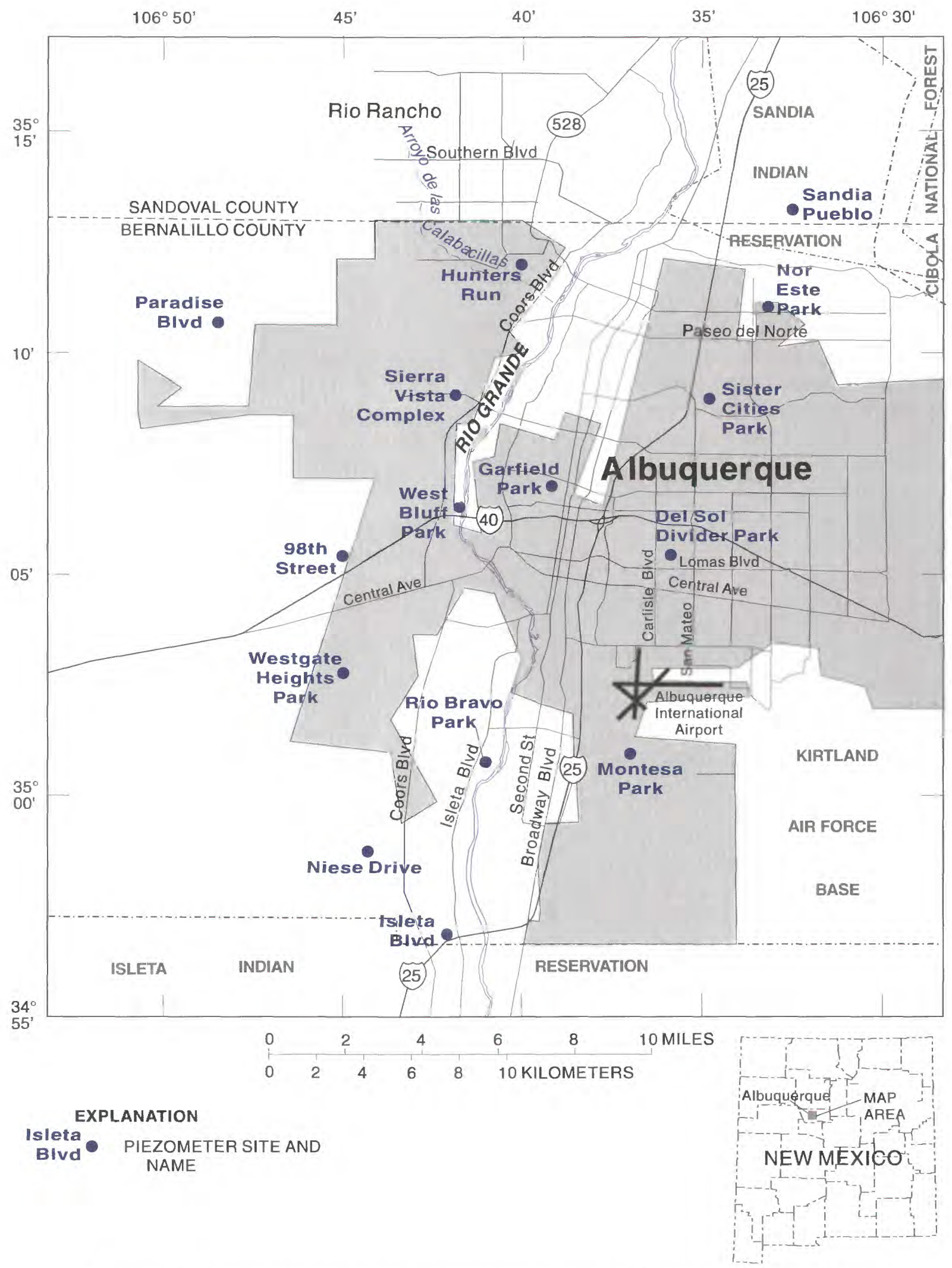

Figure 1. Piezometer sites in the metropolitan area of Albuquerque, New Mexico. 


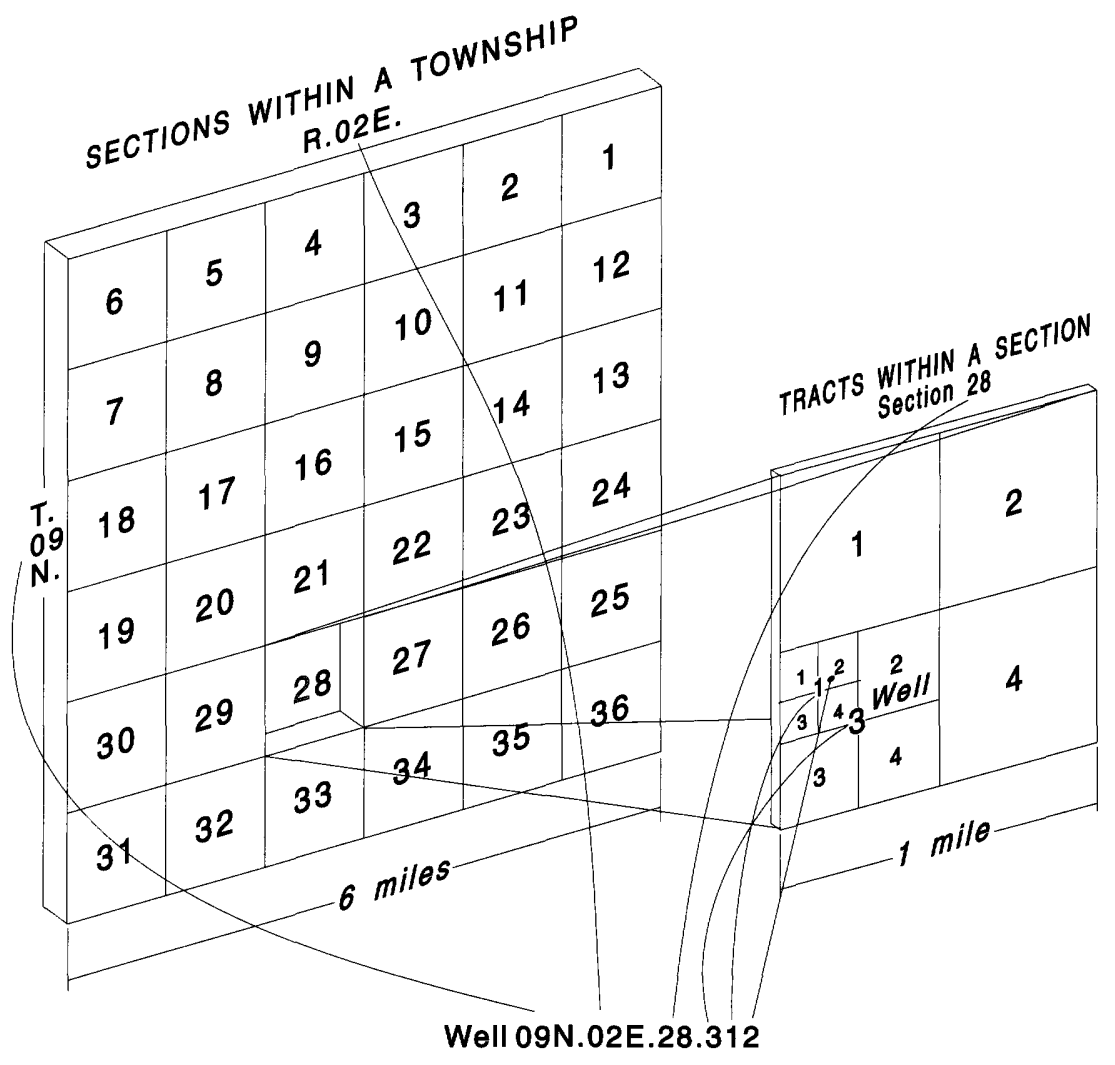

Figure 2. System of numbering wells in New Mexico used to designate piezometer sites in this report.

drilled, constructed, and developed the 50 piezometers at 15 sites from 1996 through 2001 (fig. 1). The boreholes were drilled using mud-rotary drilling. At each site, the supervising USGS hydrologist established a drilling and construction program based on the (1) location of the municipal production zone, (2) number of piezometers to be completed, and (3) estimated depth to water. At 13 sites, three or more piezometers were completed with screened intervals located (1) at the water table, (2) near the middle of the municipal production zone, and (3) near the bottom of the municipal production zone. The municipal production zone was determined by examining the screened intervals at nearby municipal production wells. The two remaining sites, Rio Bravo Park and Paradise Boulevard, have two piezometers and one piezometer, respectively.

Generally, piezometers were constructed of 2.5inch-diameter schedule-80 polyvinyl chloride (PVC) casing with stainless-steel screens ( 0.20 -inch slot size). The piezometer at the Paradise Boulevard site was constructed of 2-inch-diameter stainless-steel casing with stainless-steel screens ( 0.20 -inch slot size). The screen length varies depending on the location of the screened interval; shallow piezometers have a 5- to 100 -foot screen, whereas middle and deep piezometers have a 5- to 10-foot screen. All screens are capped with a segment of blank casing, known as a sump; generally, the shallow piezometers are capped with a 10- or 20foot sump and all other piezometers are capped with a 5 -foot sump. All piezometers are contained in steel surface casing, except the shallow piezometer at the Isleta Boulevard site.

One deep borehole was drilled at each site. Drill cuttings were collected at 5- to 10 -foot intervals and analyzed by staff of the New Mexico Bureau of Geology and Mineral Resources. Geophysical logs were run in the open borehole except at the Nor Este Park, Isleta Boulevard, and Sandia Pueblo sites. The geophysical logs include caliper logs, gamma logs, neutron logs, long-spaced density logs, short-spaced density logs, density porosity logs, neutron porosity logs, resistivity logs (long-normal logs, short-normal logs, single-point resistivity logs, 1ateral resistivity $\log$ ), spontaneous-potential logs, and electricalconductivity logs. A detailed description of the construction, development, and surface completion is available in Bartolino and Rankin (2001). 


\section{Instrumentation}

All piezometers discussed in this report have been instrumented with differential-pressure transducers to measure ground-water levels. All sites are equipped with a multichannel, electronic data logger powered by a 12-volt gel-cell battery. Transducers at a specific site are connected to the data logger, which records hourly ground-water levels. Data loggers are housed in 14-inch-diameter well shrouds with locking lids. Sites are visited every 4 to 8 weeks to (1) download data from the data loggers, (2) replace the battery, if necessary, and (3) manually measure groundwater levels in all piezometers to confirm the accuracy of pressure transducers.

\section{Acknowledgments}

The New Mexico Bureau of Geology and Mineral Resources collaborated with the USGS in analysis of samples and data collected from the boreholes. Doug Earp, City of Albuquerque, helped locate the 98th Street piezometer site. The New Mexico Department of Transportation, District 3, granted permission to locate the 98th Street piezometers in the highway right-of-way. The assistance of John Stomp, City of Albuquerque, and Jeff Peterson, Bernalillo County, is greatly appreciated.

\section{DESCRIPTION OF PIEZOMETERS}

Site and construction information for the 50 piezometers installed at 15 sites is listed in table 1 and discussed in the following sections. Geophysical logs, piezometer completion diagrams, and lithologic diagrams for each site (see fig. 23A-O) are presented in the back of the report. Piezometer configuration diagrams are presented throughout the report. Configuration diagrams show the positions of the piezometers in the surface casing relative to north.

\section{Sister Cities Park Site}

The Sister Cities Park site is located in northeast Albuquerque (fig. 3). Drilling at the Sister Cities Park site began March 1, 1996, and the total depth of about 1,325 feet was reached March 20, 1996. The three piezometers at the site are contained in 12-inchdiameter steel surface casing that extends 79 feet beneath land surface. The configuration of the piezometers is shown in figure 4. Each piezometer consists of 2.5-inch-diameter PVC casing, a stainlesssteel screen, and a PVC sump. The screened intervals range from about 350 to 450 feet, 789 to 794 feet, and 1,298 to 1,303 feet below land surface. Shortly after installation, fine-grained materials entered the casing of the shallow piezometer, which affected water-level measurements. Therefore, water-level data are no longer collected from the shallow piezometer. Geophysical logs, a completion diagram, and a lithologic diagram of the three piezometers are shown in figure 23A. Site and construction information and water-level data are listed in table 1.

\section{Del Sol Divider Park Site}

The Del Sol Divider Park site is located in northeast Albuquerque (fig. 5). Drilling at the Del Sol Divider site began April 9, 1996, and the total depth of about 1,570 feet was reached April 19, 1996. The three piezometers at the site are contained in 12-inchdiameter steel surface casing that extends 90 feet beneath land surface. The configuration of the piezometers is shown in figure 4. Each piezometer consists of 2.5-inch-diameter PVC casing, a stainlesssteel screen, and a PVC sump. The screened intervals range from about 315 to 415 feet, 853 to 858 feet, and 1,557 to 1,562 feet below land surface. Geophysical logs, a completion diagram, and a lithologic diagram of the three piezometers are shown in figure 23B. Site and construction information and water-level data are listed in table 1.

\section{Hunters Run Park Site - Nest 1}

The Hunters Run Park site is located in northwest Albuquerque (fig. 6). Drilling at the Hunters Run Park - Nest 1 site began May 9, 1996, and the total depth of about 1,520 feet was reached May 28, 1996. The three piezometers at the site are contained in 12 inch-diameter steel surface casing that extends 20 feet below land surface. The configuration of the piezometers is shown in figure 4. Each piezometer consists of 2.5-inch-diameter PVC casing, a stainlesssteel screen, and a PVC sump. The screened intervals range from about 148 to 228 feet, 845 to 850 feet, and 1,508 to 1,513 feet below land surface. Geophysical logs, a completion diagram, and a lithologic diagram of the three piezometers are shown in figure 23C. Site and construction information and water-level data are listed in table 1. 


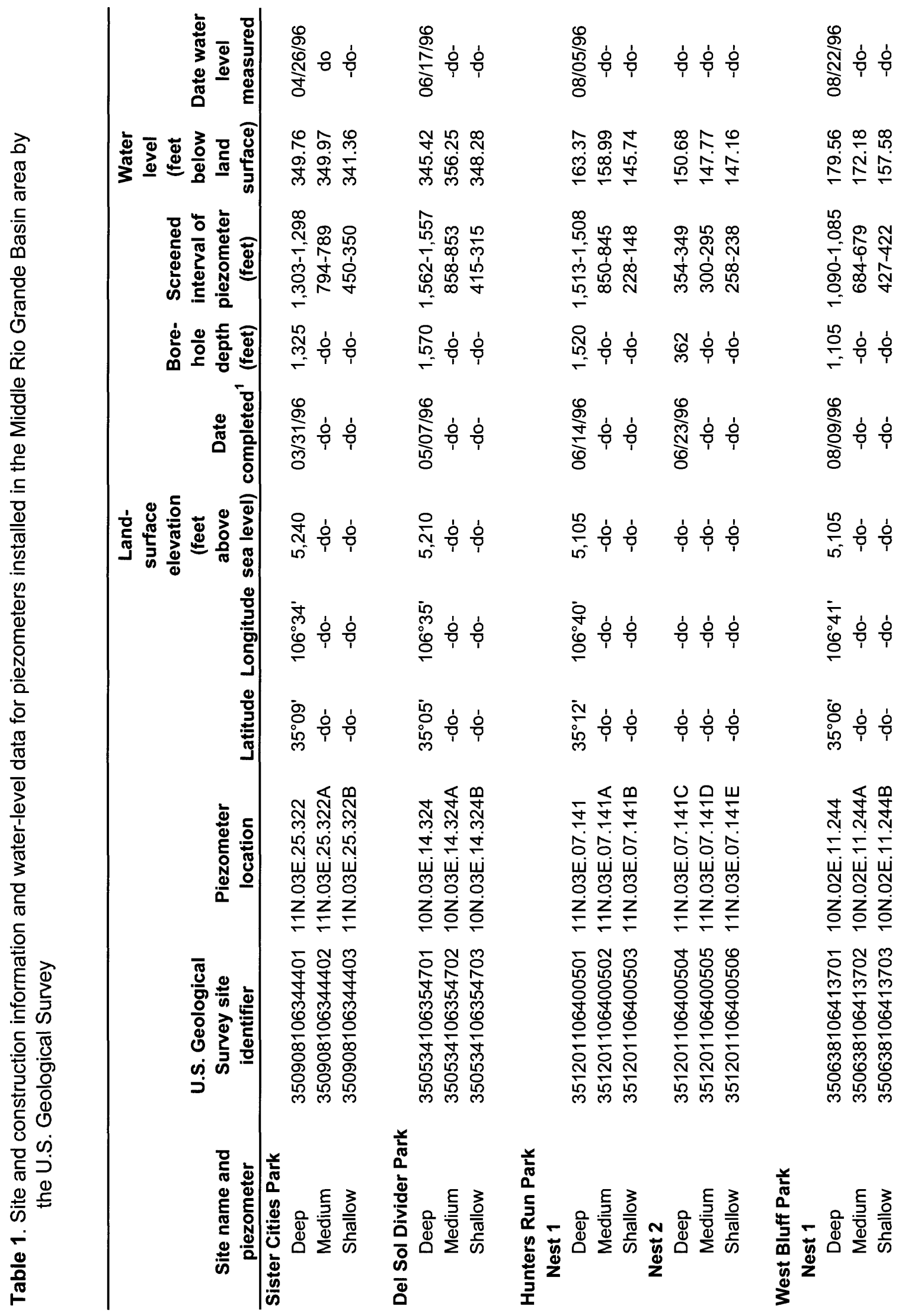




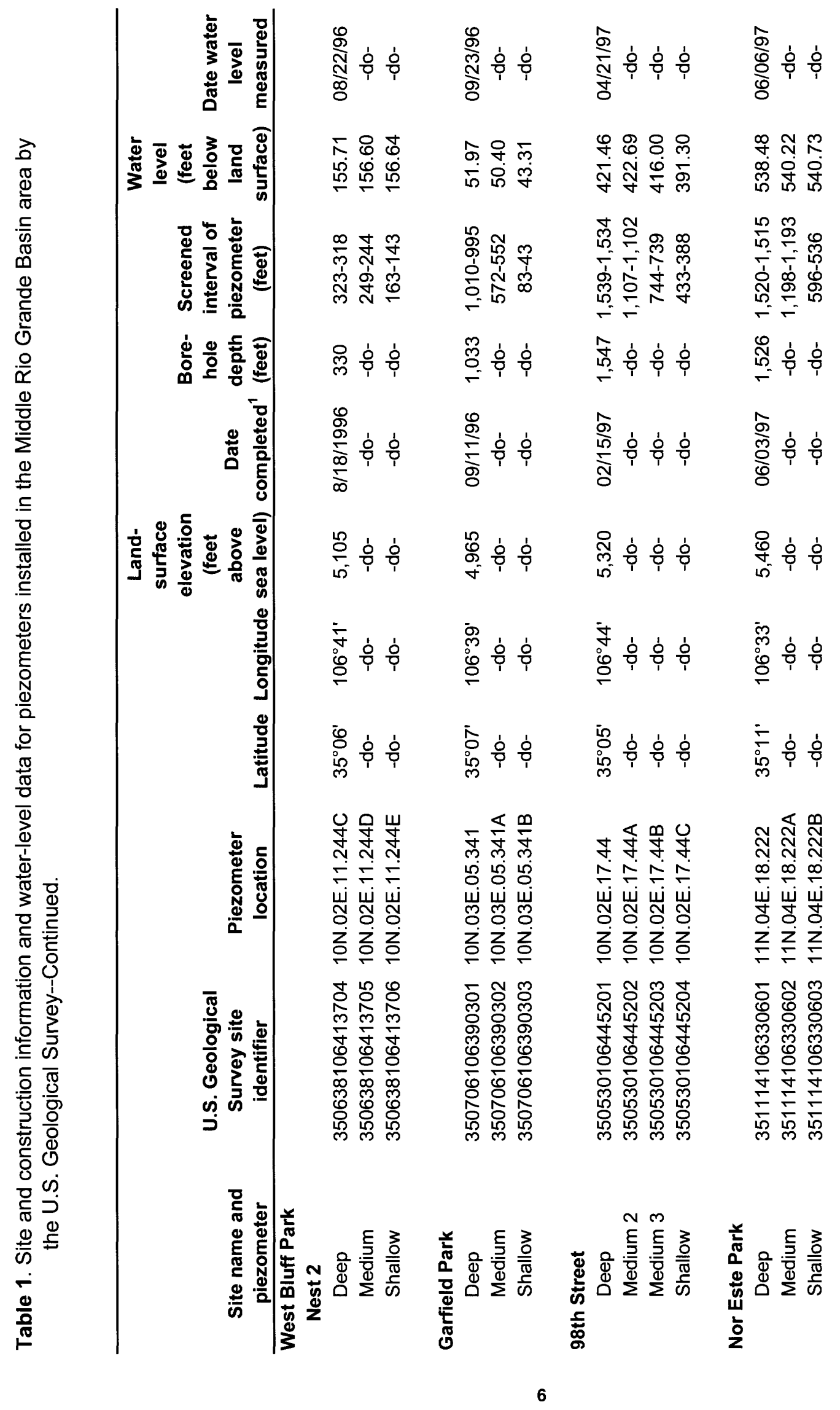




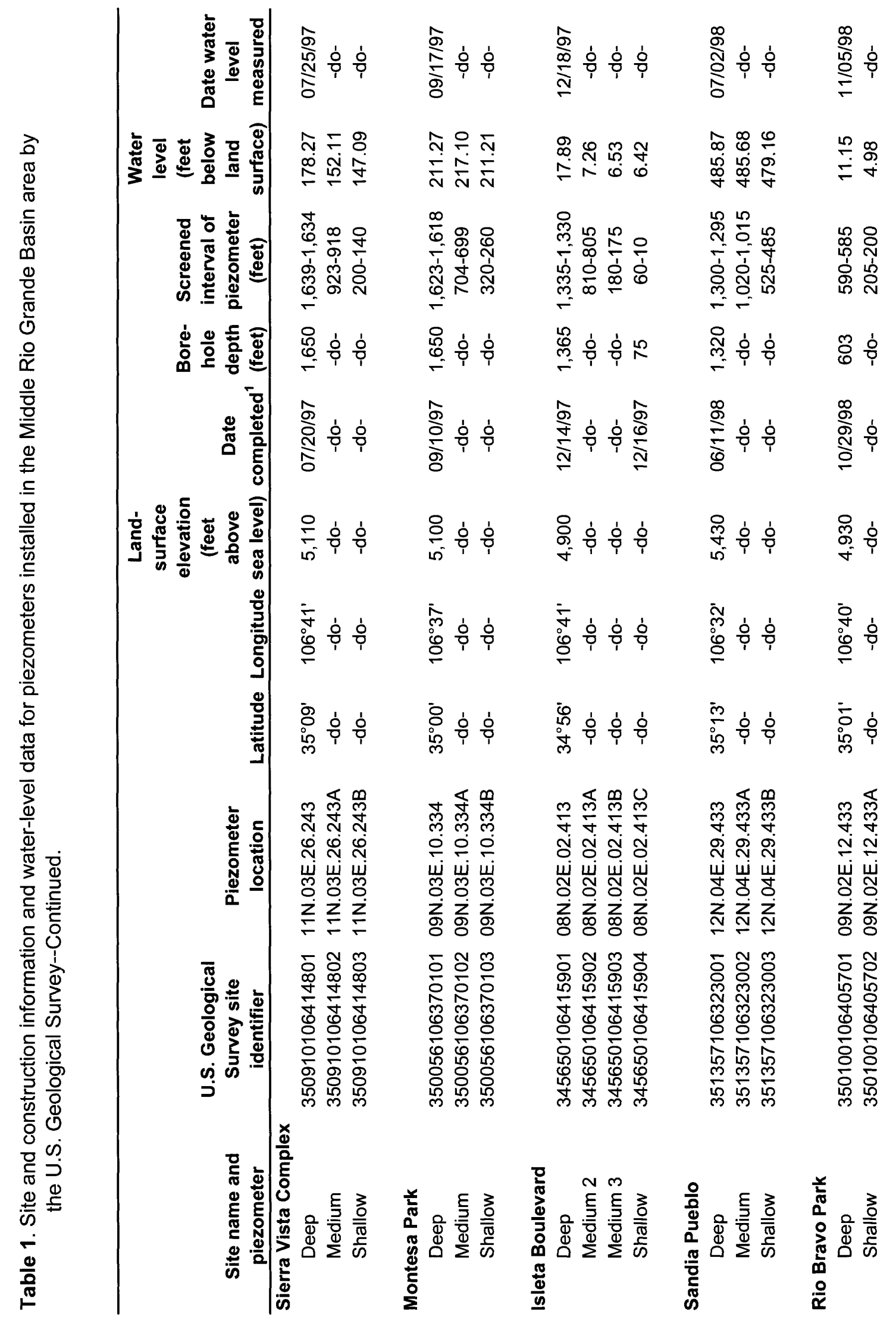




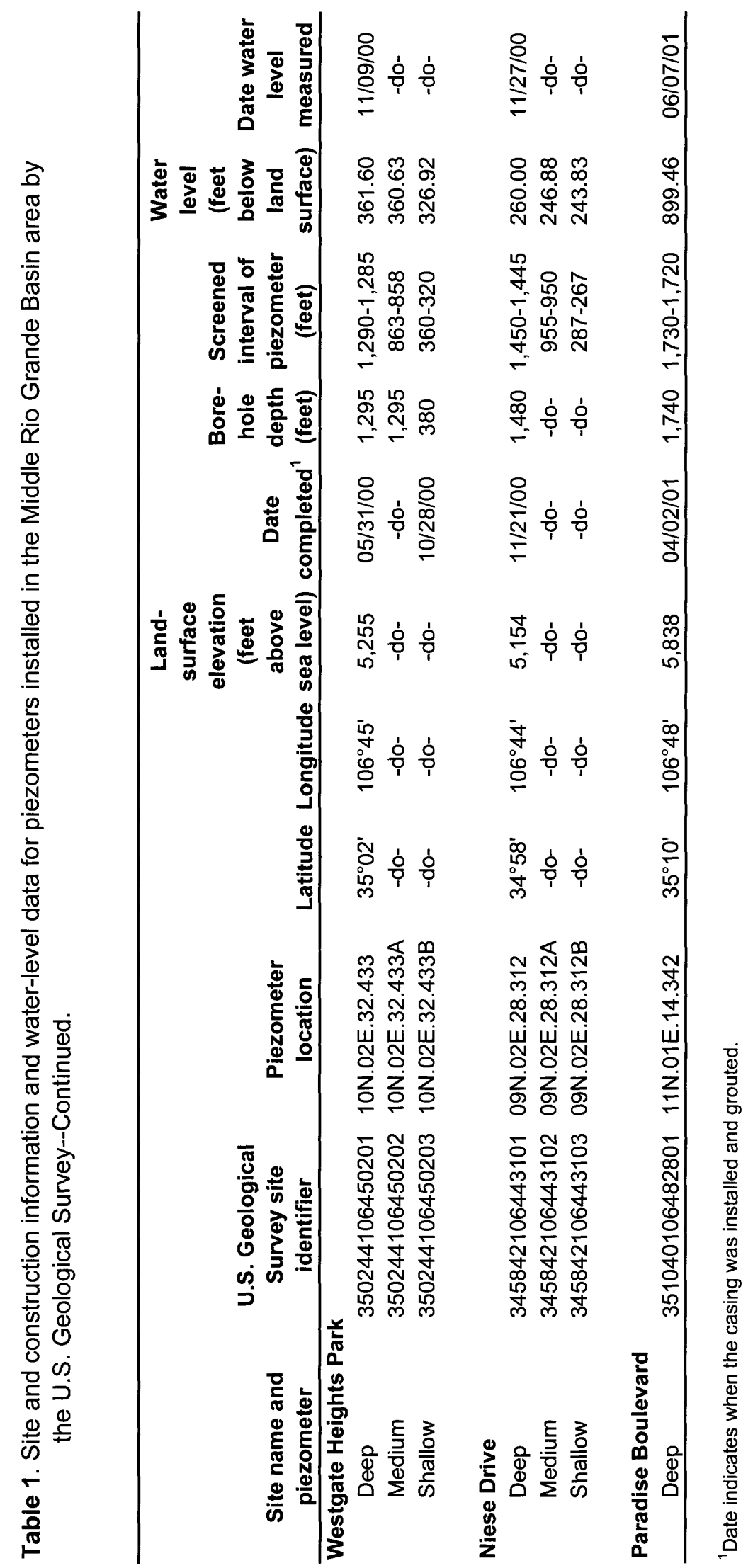




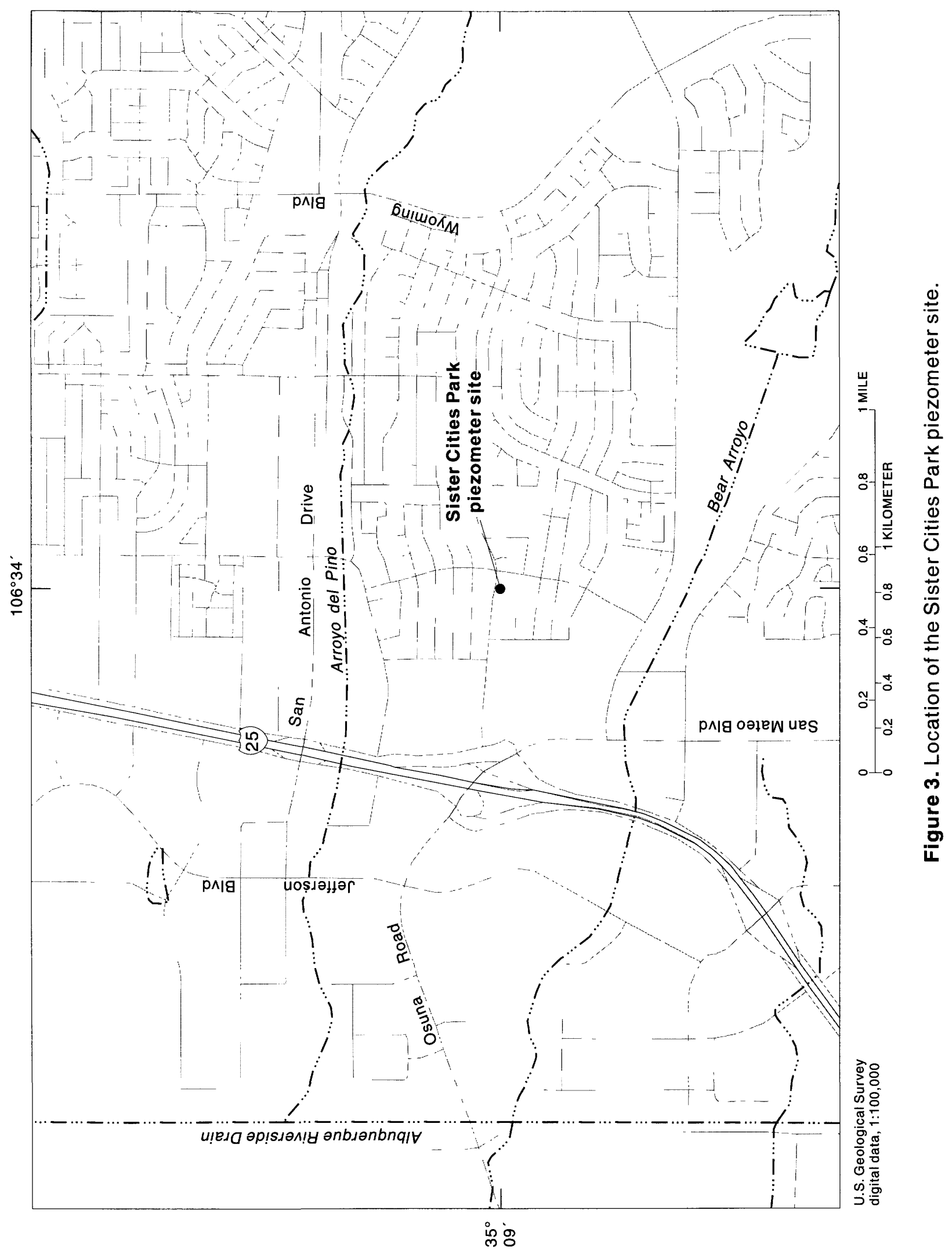




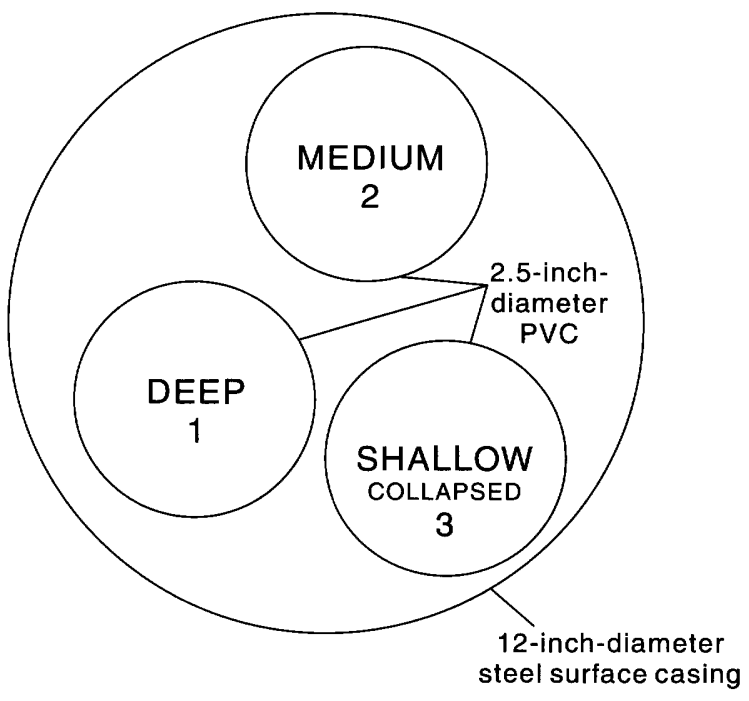

Sister Cities Park site

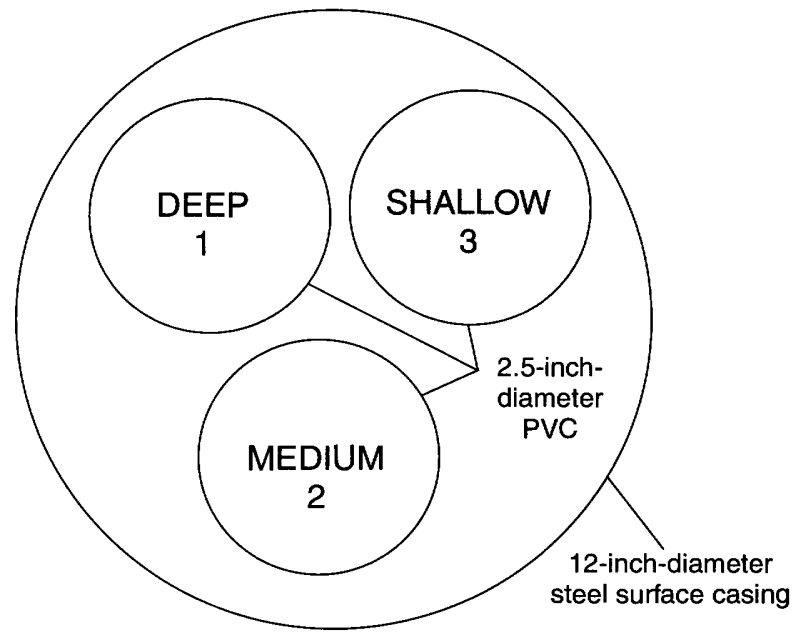

Hunters Run Park site - Nest 1

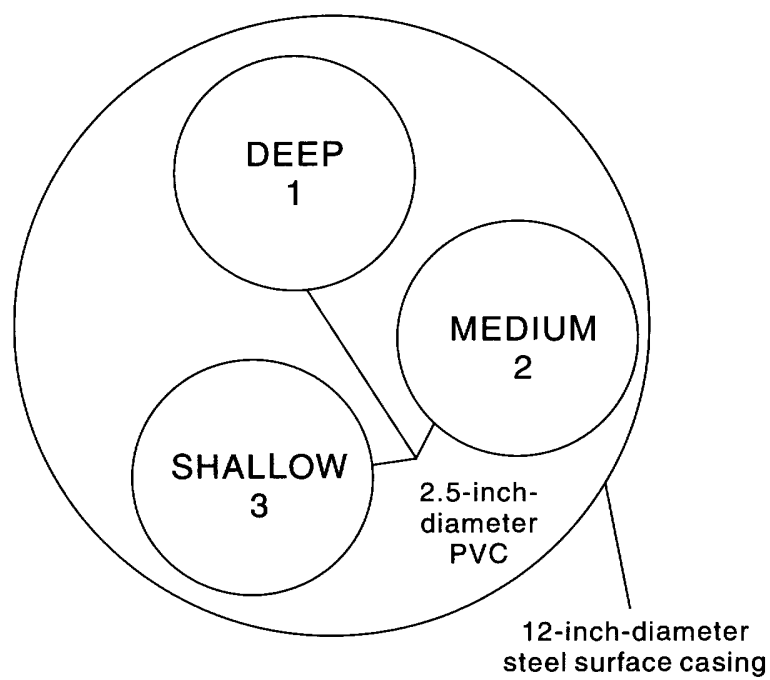

Del Sol Divider Park site

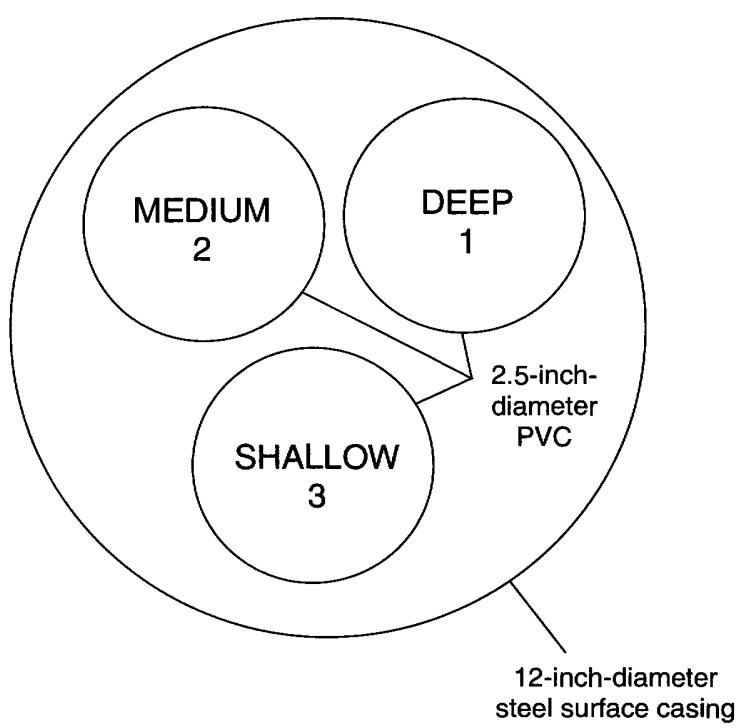

Hunters Run Park site - Nest 2

Not to scale

Figure 4. Configuration of the piezometers at the Sister Cities Park, Del Sol Divider Park, and Hunters Run Park sites. 


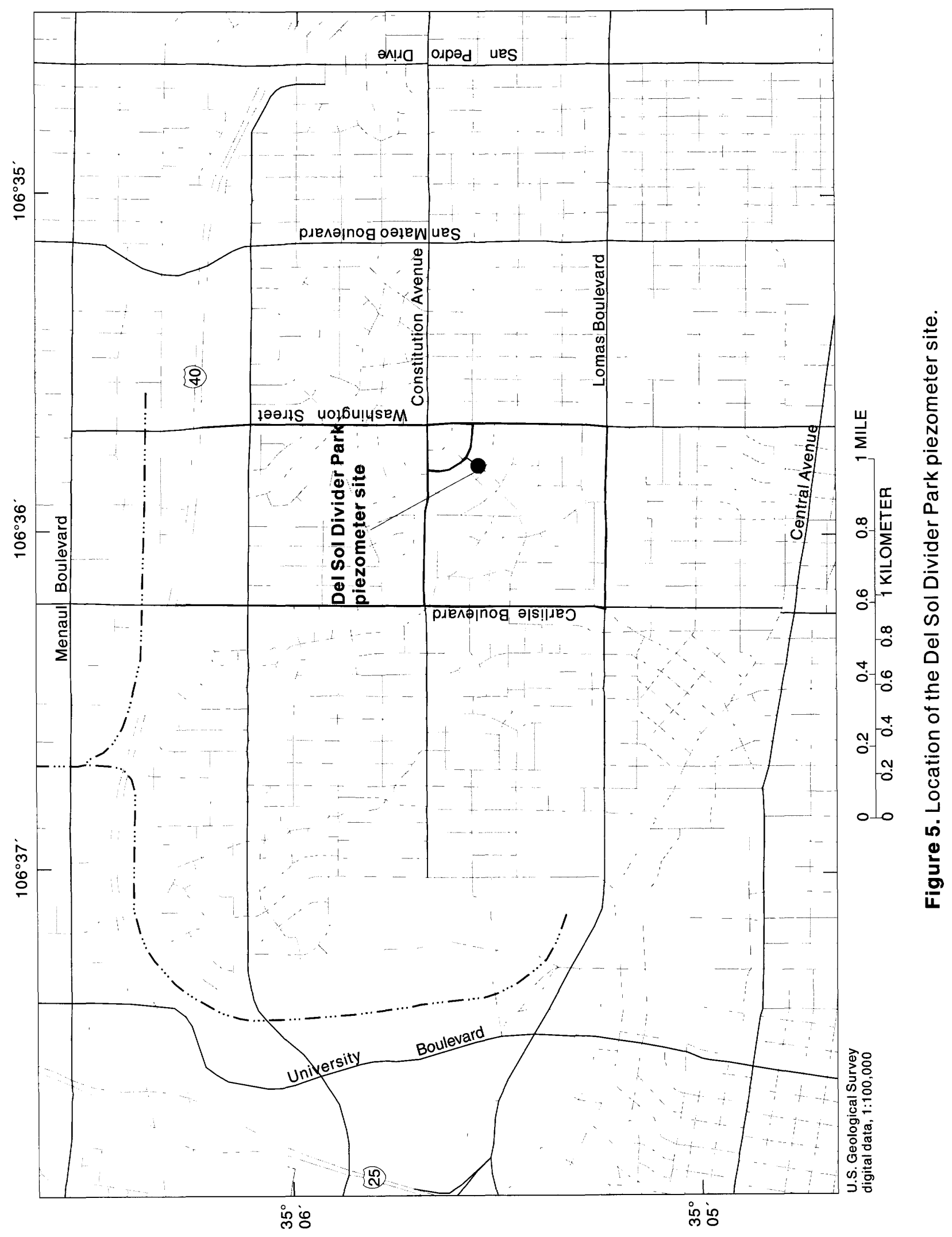




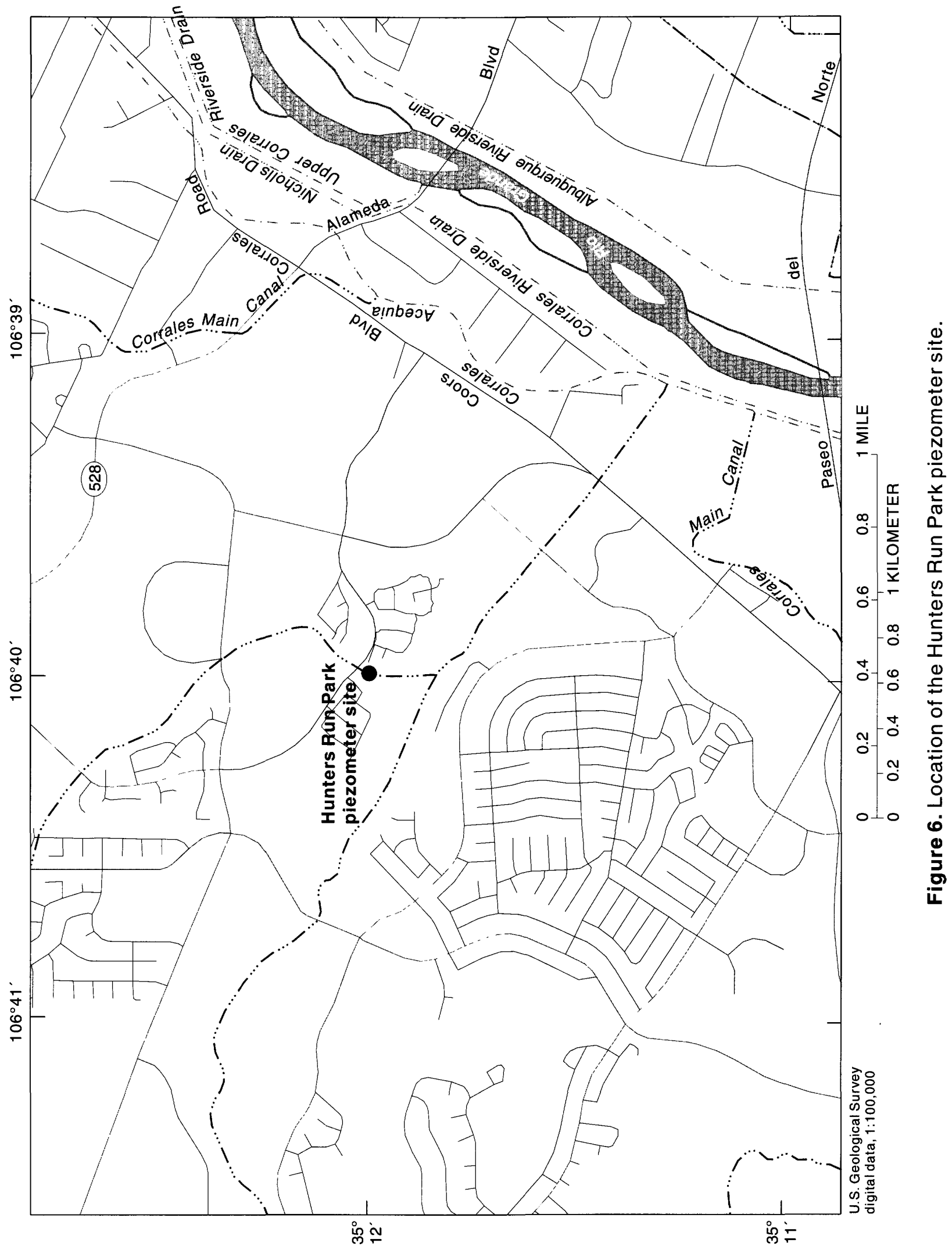




\section{Hunters Run Park Site - Nest 2}

The Hunters Run Park site is located in northwest Albuquerque. Nest 2 is located approximately 10 feet south of Nest 1 (fig. 6). Drilling at the Hunters Run Park - Nest 2 site began June 14, 1996 , and the total depth of about 362 feet was reached June 18,1996 . The three piezometers at the site are contained in 12-inch-diameter steel surface casing that extends 6 feet below land surface. The configuration of the piezometers is shown in figure 4. Each piezometer consists of 2.5-inch-diameter PVC casing, a stainlesssteel screen, and a PVC sump. The screened intervals range from about 238 to 258 feet, 295 to 300 feet, and 349 to 354 feet below land surface. Geophysical logs were run in the Nest 1 borehole and are shown in figure 23C. A completion diagram of the three piezometers and the lithologic diagram for this site, constructed from cuttings of the Nest 1 borehole, also are shown in figure 23C. Site and construction information and water-level data are listed in table 1.

\section{West Bluff Park Site - Nest 1}

The West Bluff Park site is located in northwest Albuquerque (fig. 7). Drilling at the West Bluff Park Nest 1 site began June 24, 1996, and the total depth of about 1,105 feet was reached July 10, 1996. The three piezometers at the site are contained in 12-inchdiameter steel surface casing that extends 9 feet below land surface. The configuration of the piezometers is shown in figure 8. Each piezometer consists of 2.5inch-diameter PVC casing, a stainless-steel screen, and a PVC sump. The screened intervals range from about 422 to 427 feet, 679 to 684 feet, and 1,085 to 1,090 feet below land surface. Geophysical logs, a completion diagram, and a lithologic diagram of the three piezometers are shown in figure 23D. Site and construction information and water-level data are listed in table 1.

\section{West Bluff Park Site - Nest 2}

The West Bluff Park site is located in northwest Albuquerque. Nest 2 is located approximately 10 feet west of Nest 1 (fig. 7). Drilling at the West Bluff - Nest 2 site began August 9, 1996, and the total depth of 330 feet was reached August 11, 1996. The three piezometers at the site are contained in 12-inchdiameter steel surface casing. The configuration of the piezometers is shown in figure 8 . Each piezometer consists of 2.5-inch-diameter PVC casing, a stainless- steel screen, and a PVC sump. The screened intervals range from about 143 to 163 feet, 244 to 249 feet, and 318 to 323 feet below land surface. Geophysical logs were not run in the Nest 2 borehole. A completion diagram of the three piezometers and lithologic diagram for this site, constructed from cuttings of the Nest 1 borehole, also are shown in figure 23D. Site and construction information and water-level data are listed in table 1.

\section{Garfield Park Site}

The Garfield Park site is located in northwest Albuquerque (fig. 9). Drilling at the Garfield site began August 19, 1996, and the total depth of about 1,033 feet was reached September 3, 1996. The three piezometers at the site are contained in 12-inch-diameter steel surface casing that extends 5 feet below land surface. The configuration of the piezometers is shown in figure 8. Each piezometer consists of 2.5-inch-diameter PVC casing, a stainless-steel screen, and a PVC sump. The screened intervals range from about 43 to 83 feet, 552 to 572 feet, and 995 to 1,010 feet below land surface. Geophysical logs, a completion diagram, and a lithologic diagram of the three piezometers are shown in figure 23E. Site and construction information and water-level data are listed in table 1 .

\section{8th Street Site}

The 98th Street site is located in northwest Albuquerque (fig. 10). Drilling at the 98th Street site began November 21, 1996, and the total depth of about 1,547 feet was reached February 3, 1997. The four piezometers at the site are contained in 12-inchdiameter steel surface casing that extends 19 feet below land surface. The configuration of the piezometers is shown in figure 8. Each piezometer consists of 2.5inch-diameter PVC casing, a stainless-steel screen, and a PVC sump. The screened intervals range from about 388 to 433 feet, 739 to 744 feet, 1,102 to 1,107 feet, and 1,534 to 1,539 feet below land surface. Geophysical logs, a completion diagram, and a generalized lithologic diagram of the four piezometers are shown in figure 23F. Site and construction information and water-level data are listed in table 1 . The 98 th Street stratigraphic core hole is approximately 60 feet south of the 98th Street site (fig. 10). Detailed information about the 98th Street stratigraphic core hole is available in Stone and others (1998). 


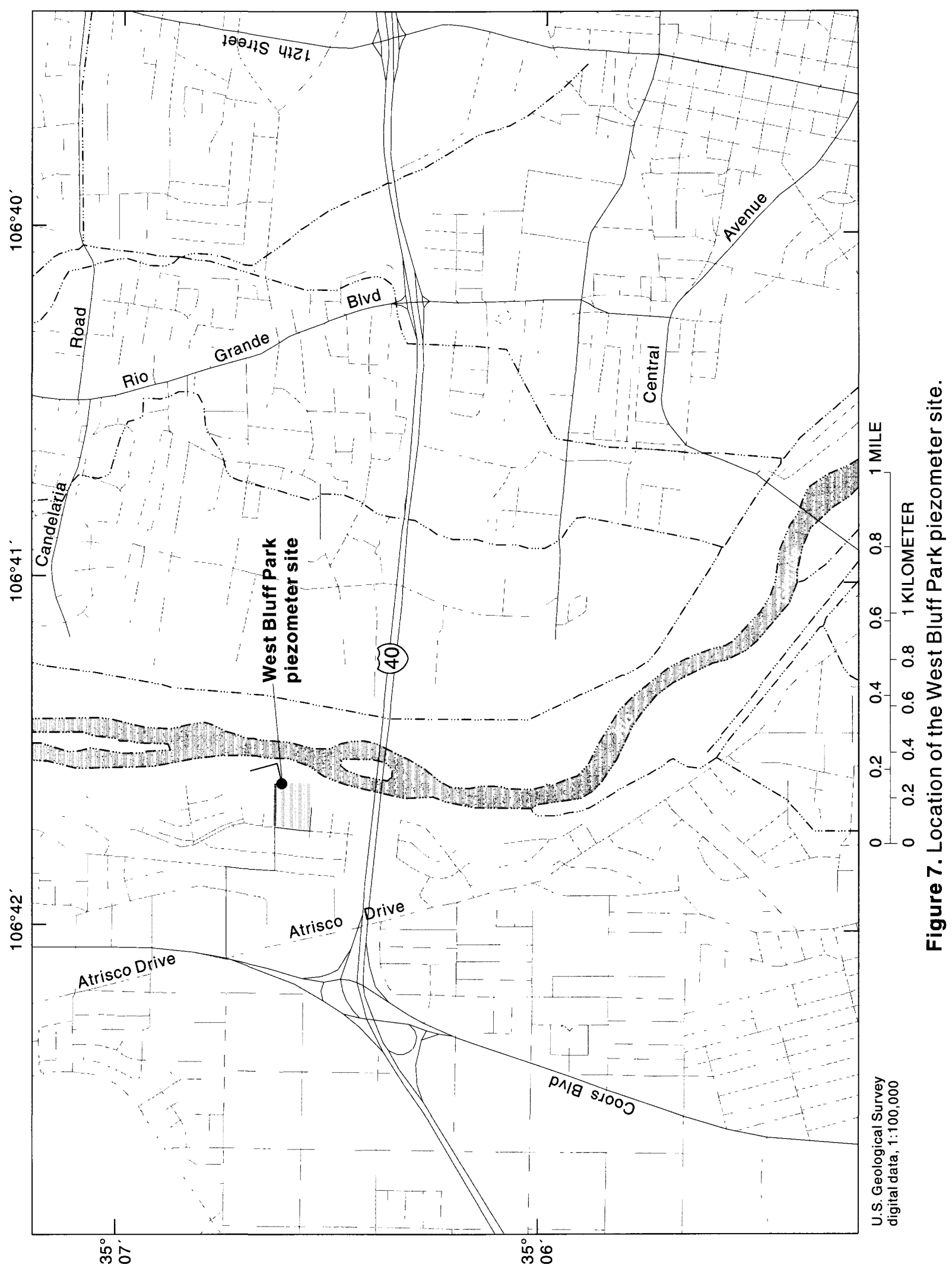




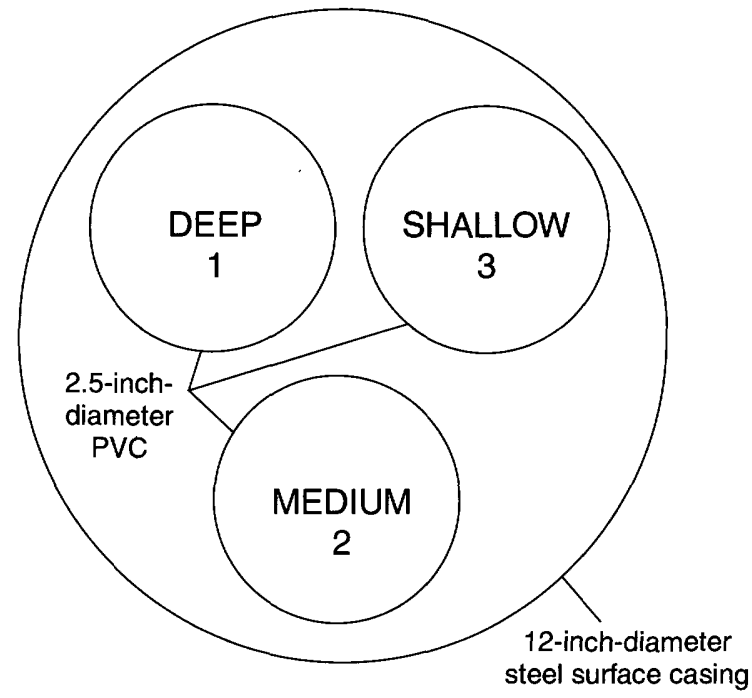

West Bluff Park site - Nest 1

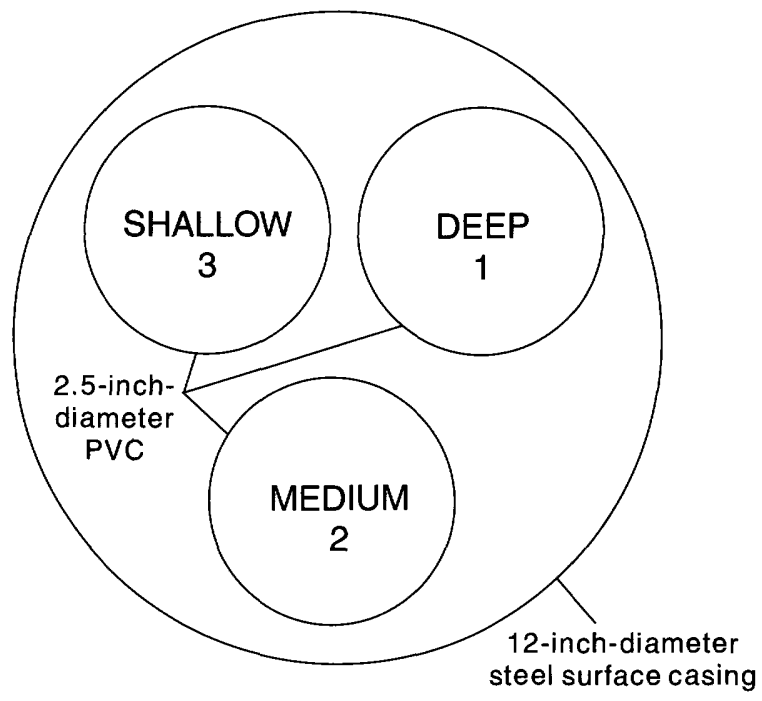

Garfield Park site

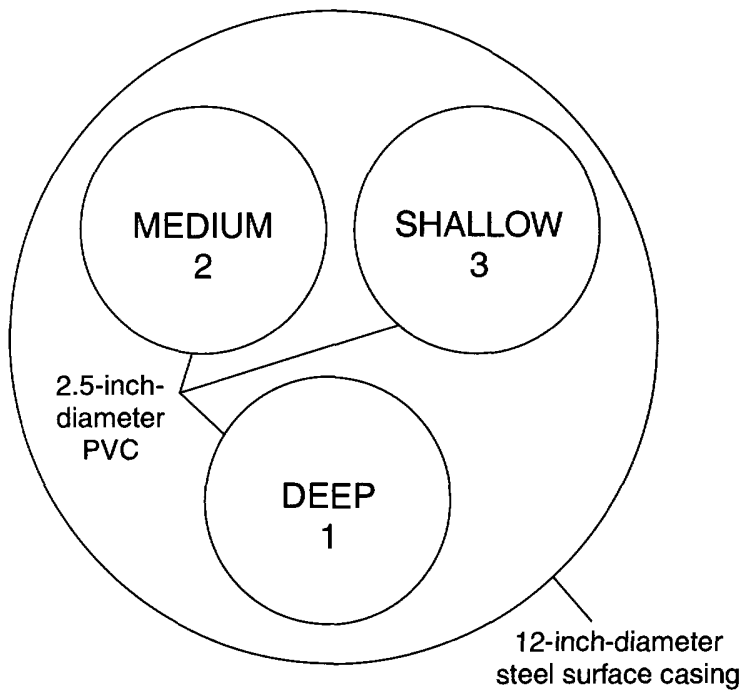

West Bluff Park site - Nest 2

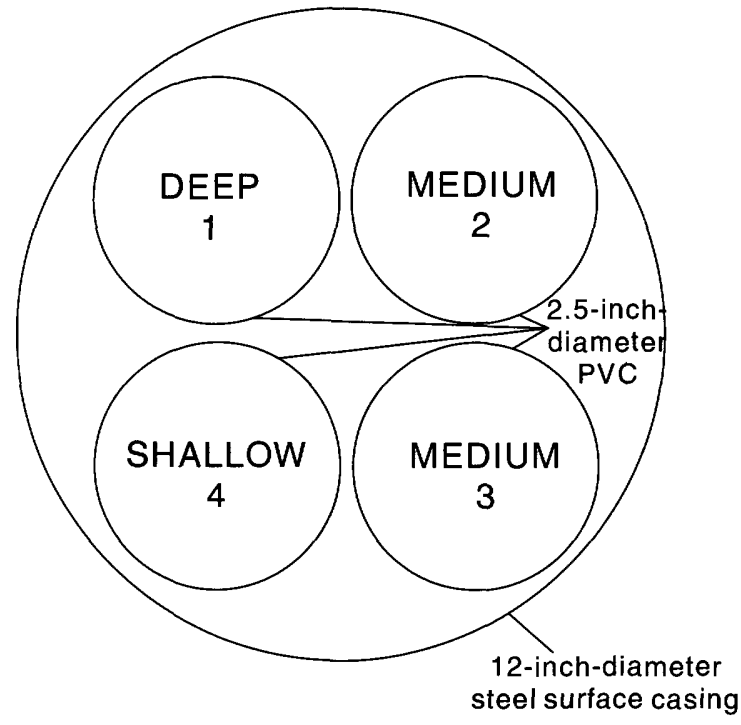

98th Street site

Not to scale

Figure 8. Configuration of the piezometers at the West Bluff Park, Garfield Park, and 98th Street sites. 


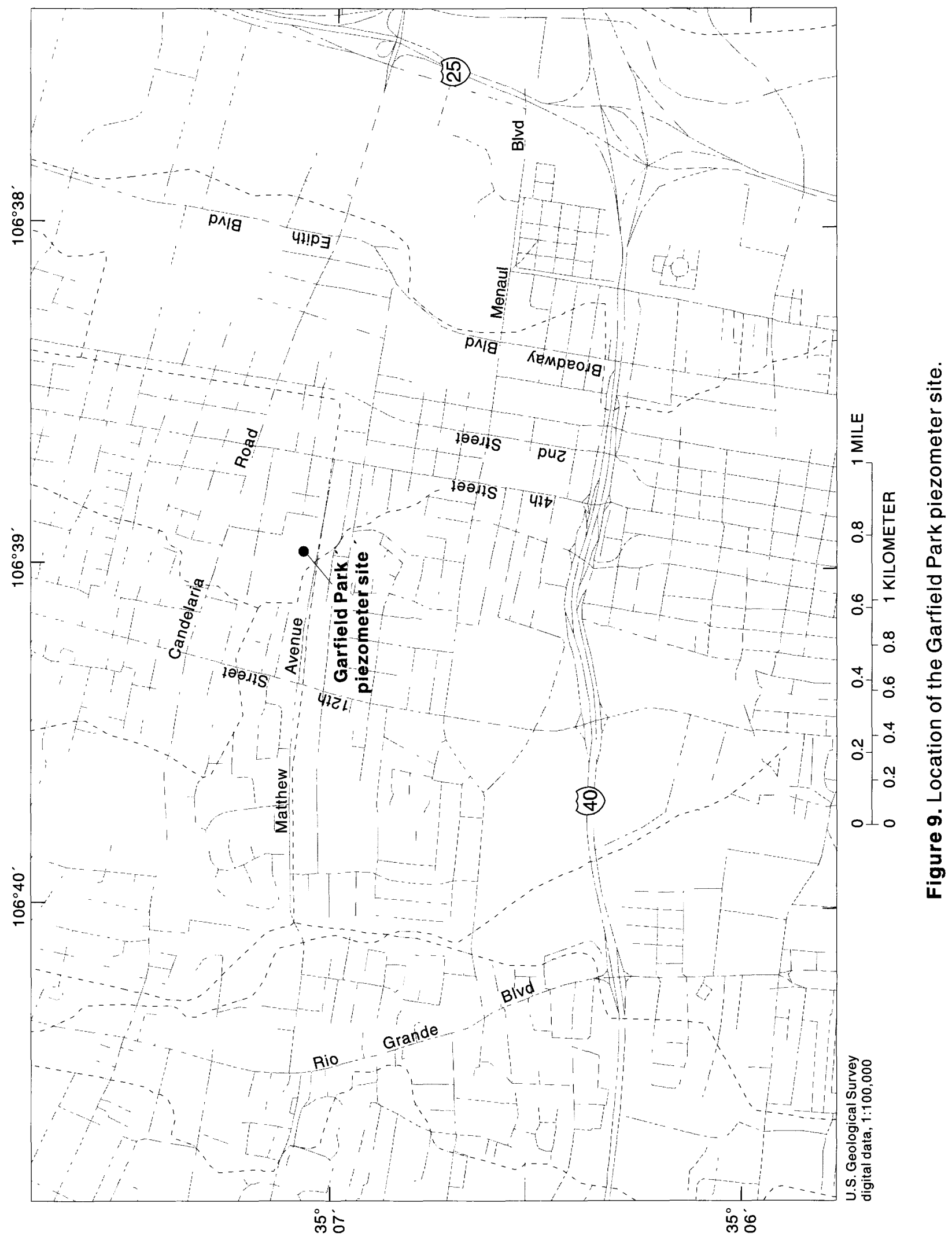




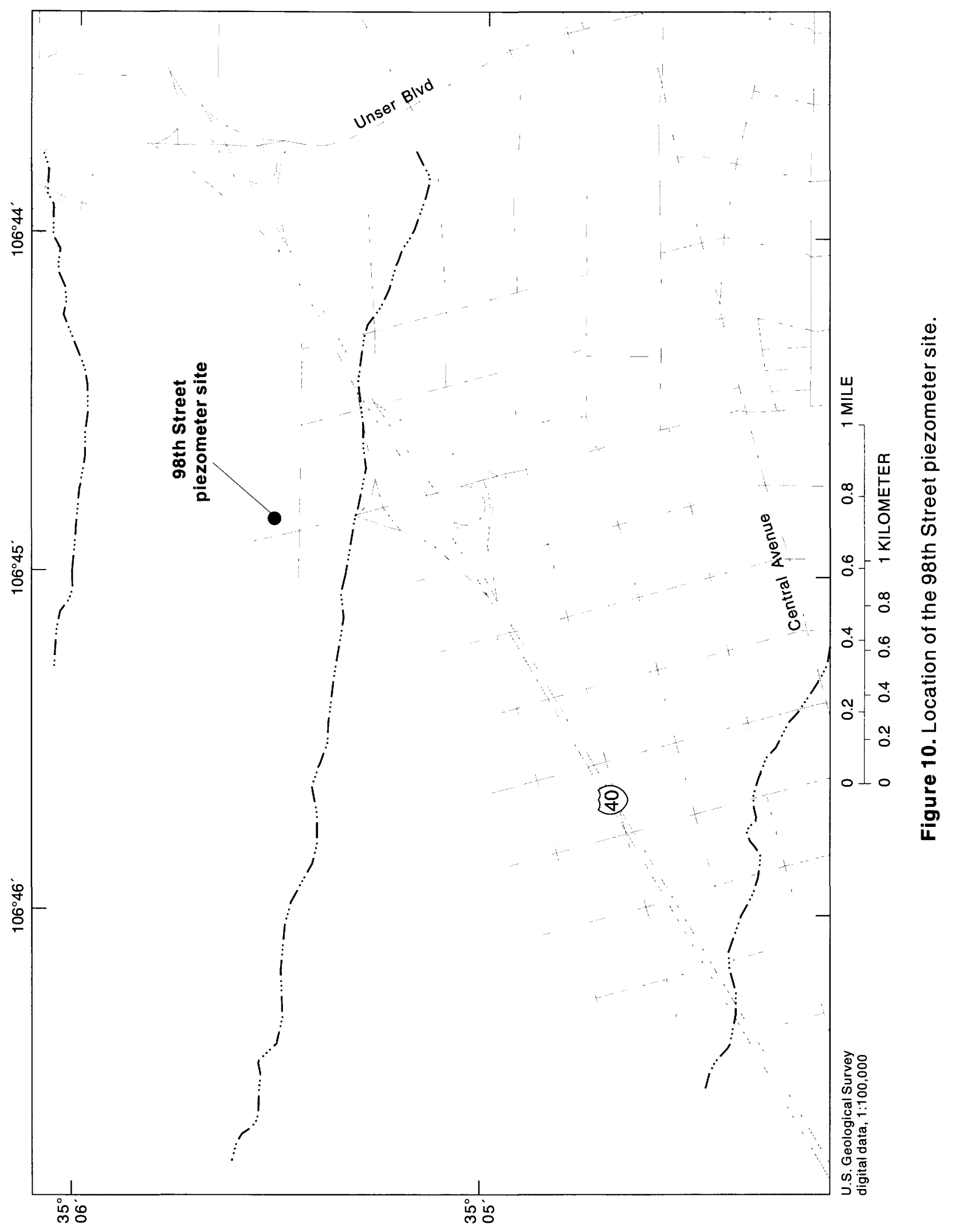




\section{Nor Este Park Site}

The Nor Este Park site is located in northeast Albuquerque (fig. 11). Drilling at the Nor Este Park site began April 18, 1997, and the total depth of about 1,526 feet was reached May 23, 1997. The three piezometers at the site are contained in 12-inchdiameter steel surface casing that extends 38.5 feet below land surface. The configuration of the piezometers is shown in figure 12. Each piezometer consists of 2.5-inch-diameter PVC casing, a stainlesssteel screen, and a PVC sump. The screened intervals range from about 536 to 596 feet, 1,183 to 1,188 feet, and 1,515 to 1,520 feet below land surface. The geophysical logs were run inside the deep piezometer; therefore, the presence of steel surface casing, stainless-steel screens, sand pack, and bentonite are evident in the logs. Geophysical logs, a completion diagram, and a generalized lithologic diagram of the three piezometers are shown in figure 23G. Site and construction information and water-level data are listed in table 1.

\section{Sierra Vista Complex Site}

The Sierra Vista Complex site is located in northwest Albuquerque (fig. 13). Drilling at the Sierra Vista Complex site began June 18, 1997, and the total depth of about 1,650 feet was reached June 29, 1997. The three piezometers at the site are contained in 12 inch-diameter steel surface casing that extends 3 feet below land surface. The configuration of the piezometers is shown in figure 12. Each piezometer consists of 2.5-inch-diameter PVC casing, a stainlesssteel screen, and a PVC sump. The screened intervals range from about 140 to 200 feet, 918 to 923 feet, and 1,634 to 1,639 feet below land surface. Geophysical logs, a completion diagram, and a generalized lithologic diagram of the three piezometers are shown in figure $23 \mathrm{H}$. Site and construction information and water-level data are listed in table 1.

\section{Montesa Park Site}

The Montesa Park site is located in southeast Albuquerque (fig. 14). Drilling at the Montesa Park site began August 7, 1997, and the total depth of about 1,650 feet was reached August 20, 1997. The three piezometers at the site are contained in 12-inch- diameter steel surface casing that extends 3 feet below land surface. The configuration of the piezometers is shown in figure 12 . The deep and medium piezometers consist of 2.5-inch-diameter PVC casing, a stainlesssteel screen, and a PVC sump. The shallow piezometer consists of 2.5-inch-diameter PVC casing, a PVC screen, and a PVC sump. The screened intervals range from about 260 to 320 feet, 699 to 704 feet, and 1,618 to 1,623 feet below land surface. Geophysical logs, a completion diagram, and a generalized lithologic diagram of the three piezometers are shown in figure 23I. Site and construction information and water-level data are listed in table 1.

\section{Isleta Boulevard Site}

The Isleta Boulevard site is located in southwest Albuquerque (fig. 15). Four piezometers were installed at the Isleta Boulevard site. Three of the piezometers are contained in 12-inch-diameter steel surface casing that extends 72 feet below land surface. A fourth piezometer was installed in a separate borehole approximately 20 feet south of the nested piezometers. The configuration of the piezometers is shown in figure 16. Each piezometer consists of 2.5-inch-diameter PVC casing, a stainless-steel screen, and a PVC sump. The screened intervals range from about 10 to 60 feet, 175 to 180 feet, 807 to 812 feet, and 1,330 to 1,335 feet below land surface.

Drilling at the nested piezometers location began November 14, 1997, and the total depth of about 1,365 feet was reached November 25, 1997. Drilling at the Isleta Boulevard shallow piezometer location began and the total depth of about 75 feet was reached on December 14, 1997. Geophysical logs were run in the borehole of the nested piezometers and are shown in figure 23J. The geophysical logs were run inside the deep piezometer; therefore, the presence of steel surface casing, stainless-steel screens, sand pack, and bentonite are evident in the logs. Completion diagrams of the four piezometers also are shown in figure 23J. The generalized lithologic diagram for the shallow piezometer site was constructed from the cuttings of the borehole of the nested piezometers. Site and construction information and water-level data are listed in table 1 . 


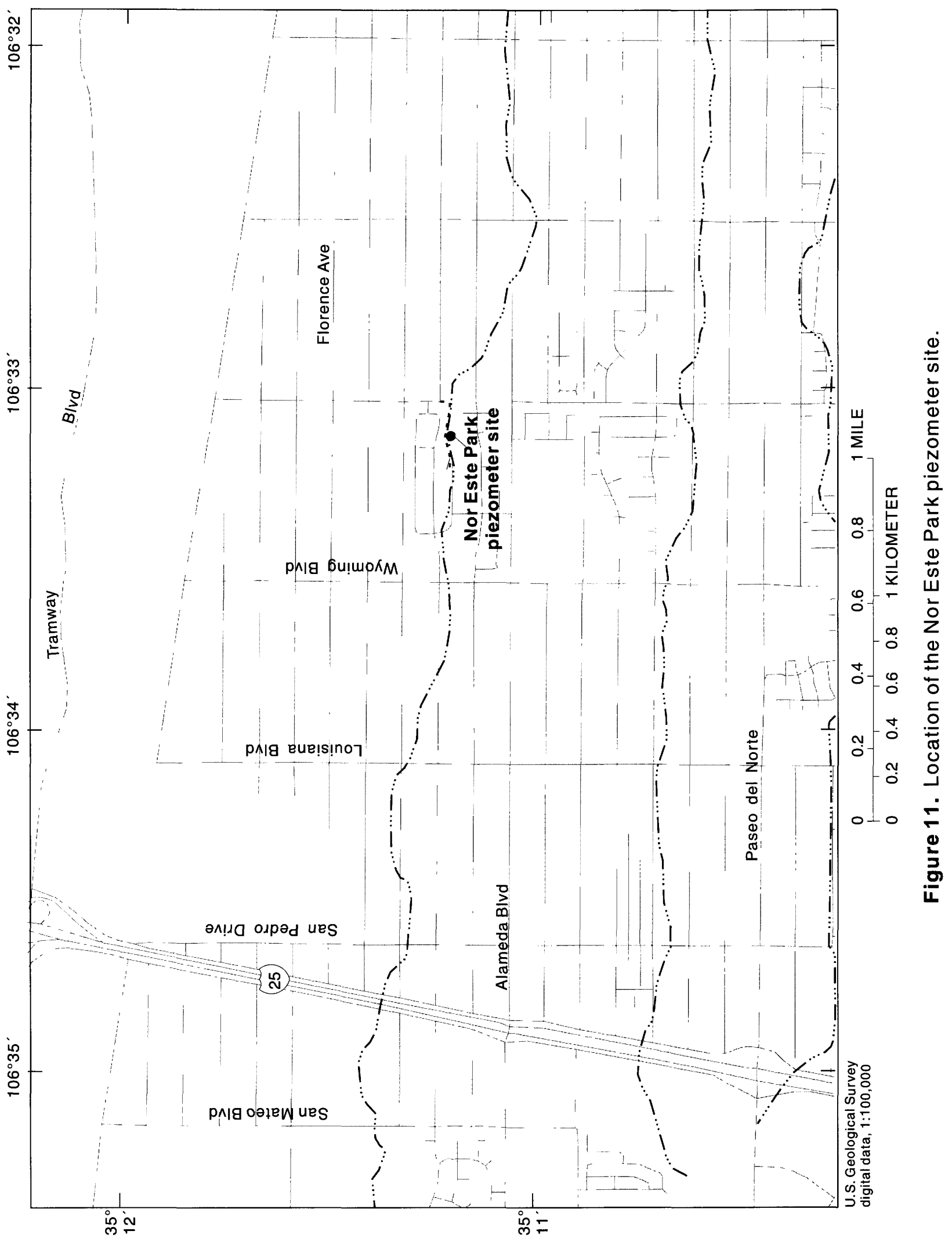




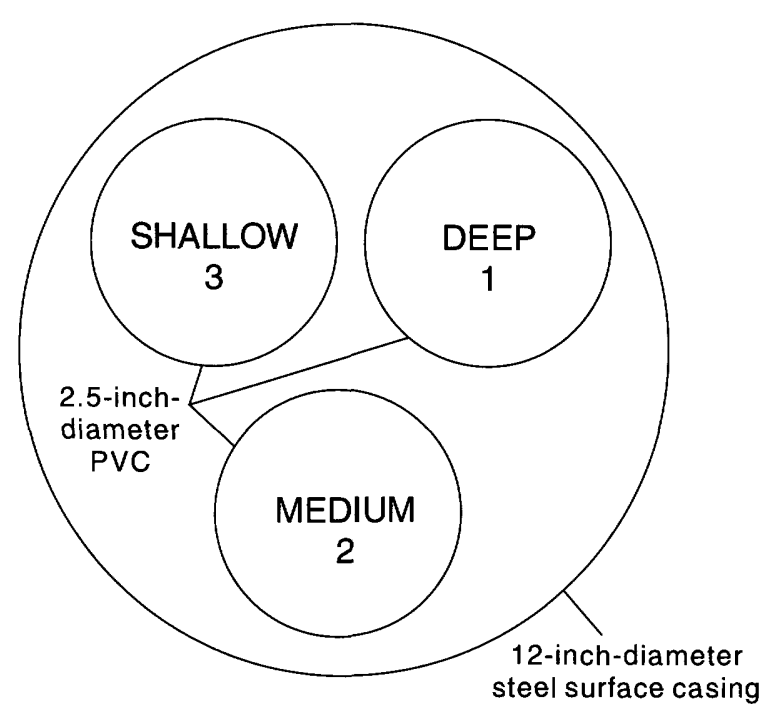

Nor Este Park site

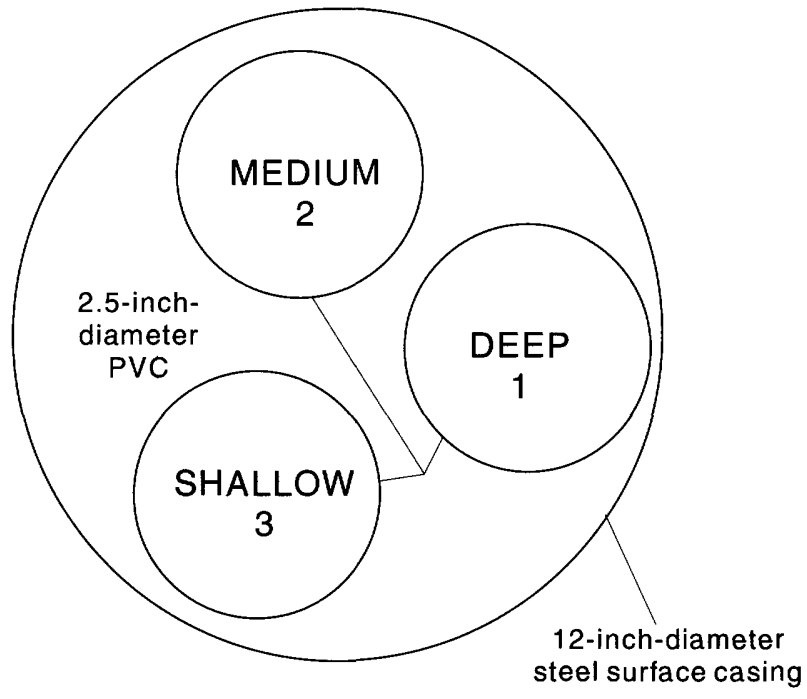

Sierra Vista Complex site

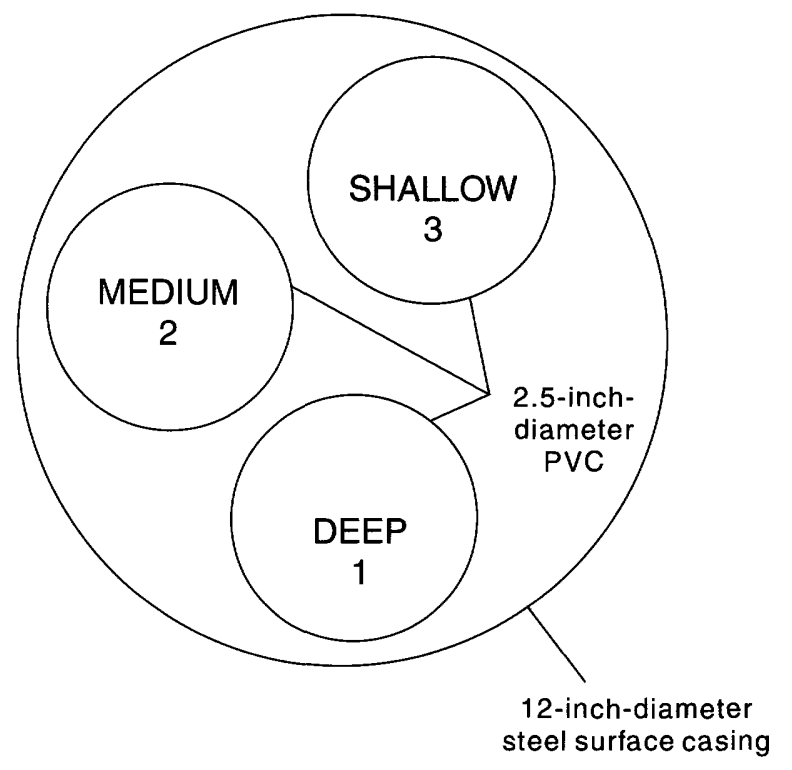

Montesa Park site

Not to scale

Figure 12. Configuration of the piezometers at the Nor Este Park, Sierra Vista Complex, and Montesa Park sites. 


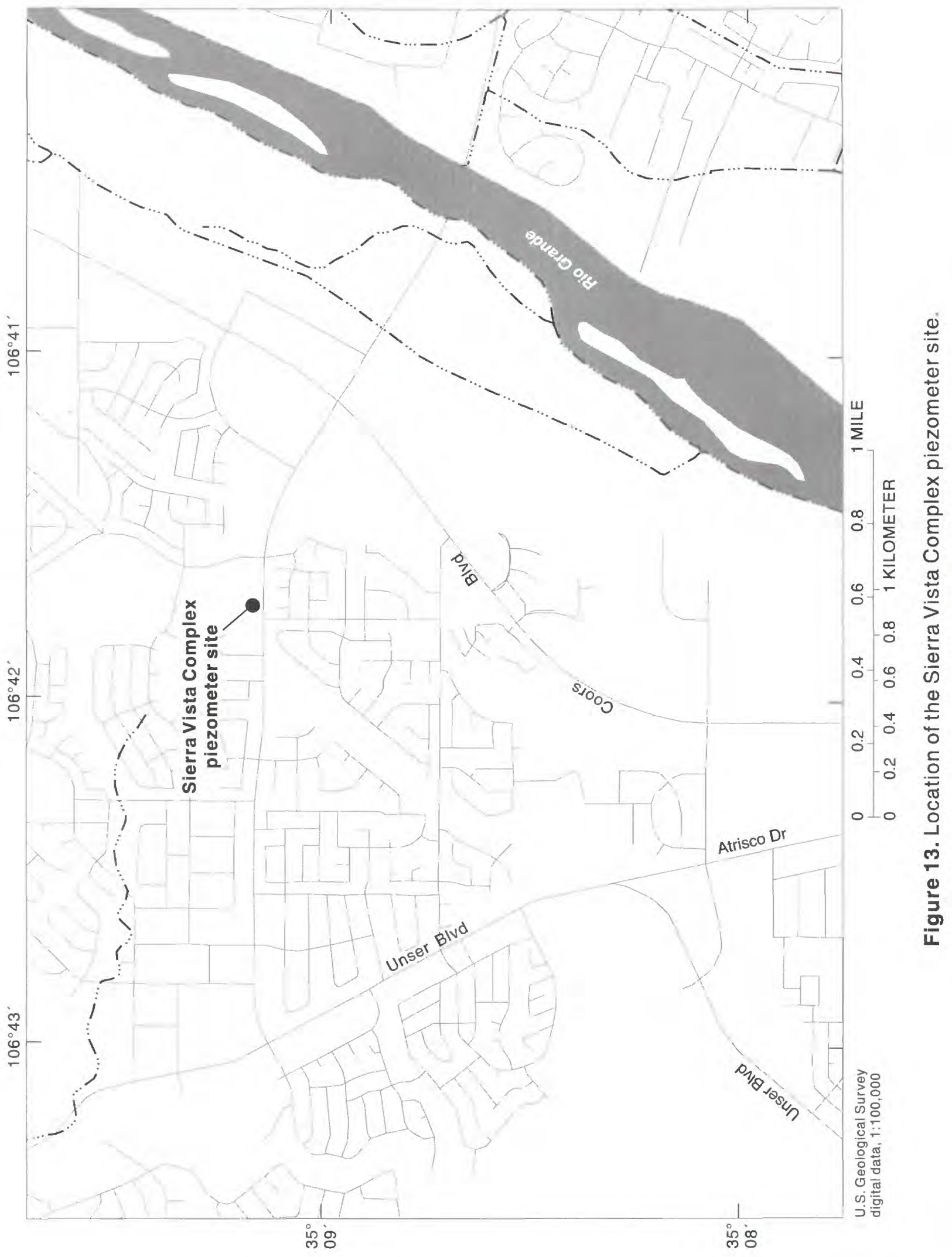




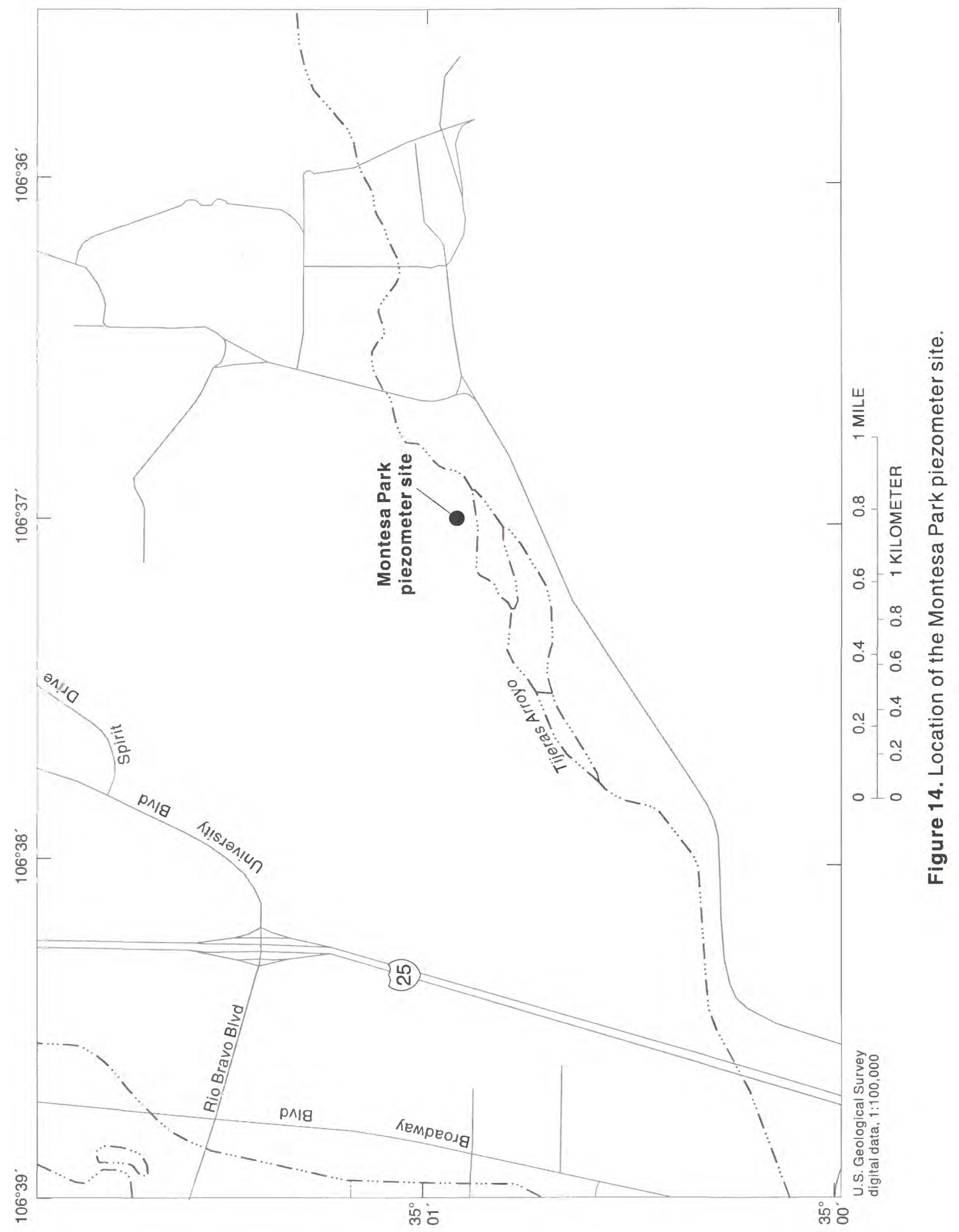




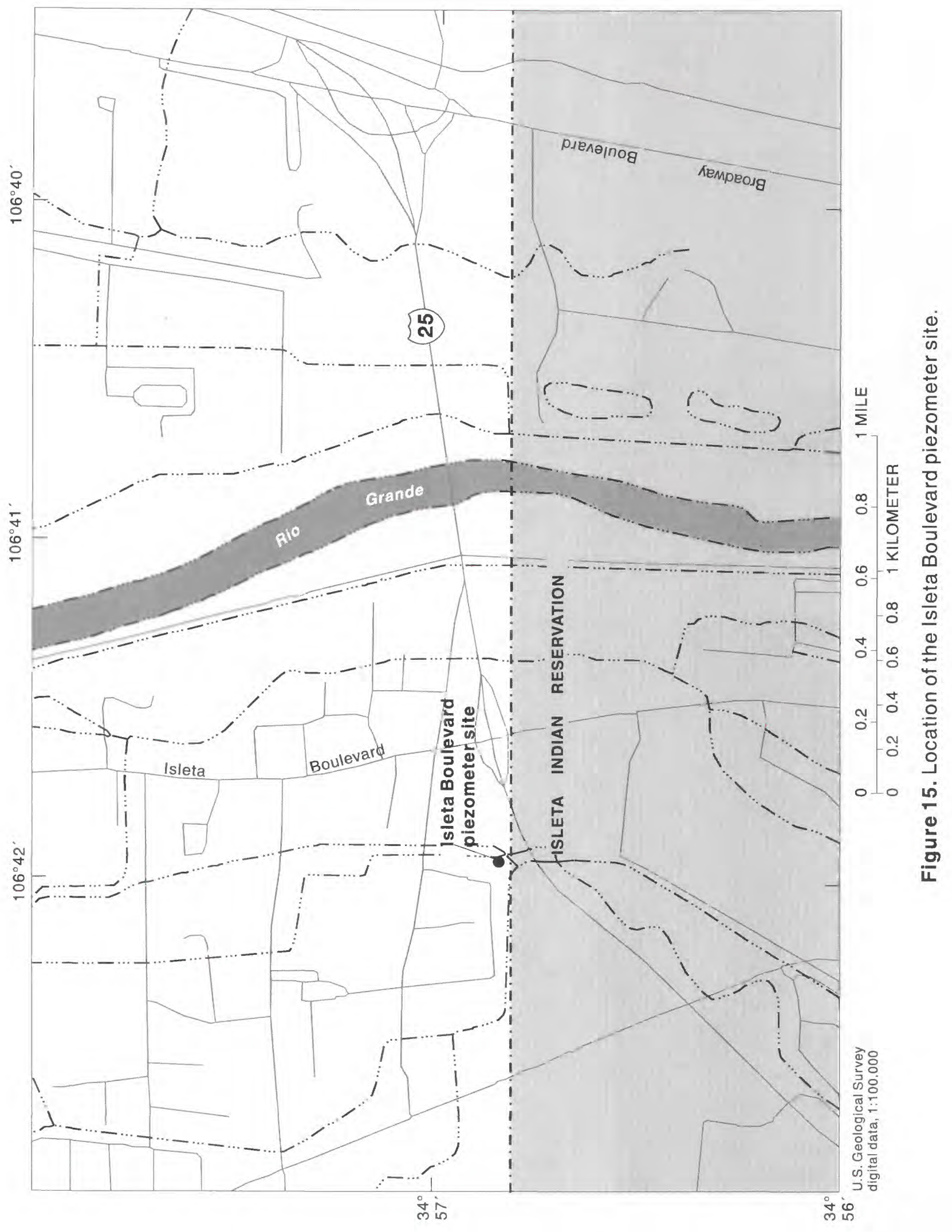




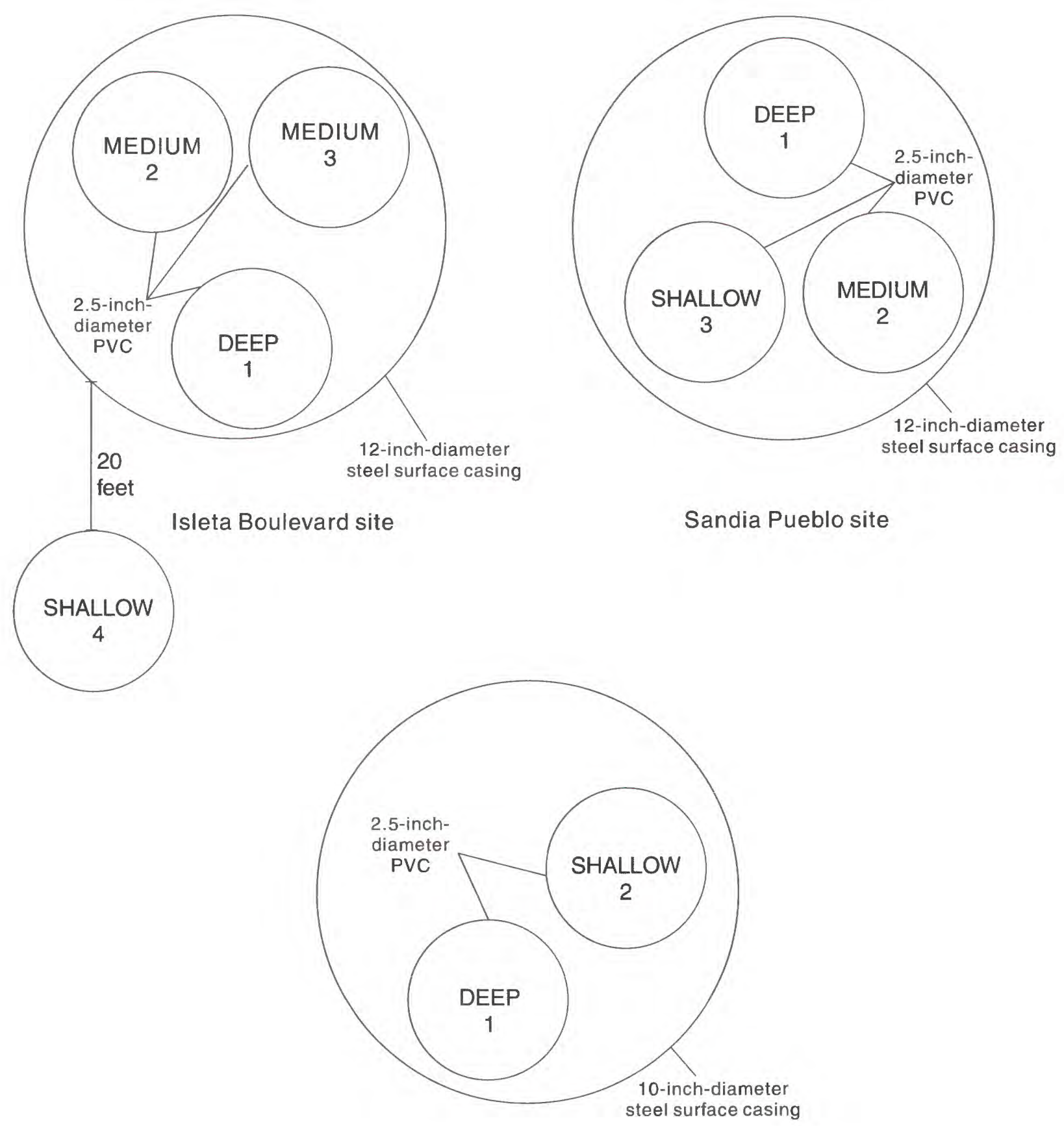

Rio Bravo Park site

Not to scale

Figure 16. Configuration of the piezometers at the Isleta Boulevard, Sandia Pueblo, and Rio Bravo Park sites. 


\section{Sandia Pueblo Site}

The Sandia Pueblo site is located on the Sandia Indian Reservation (fig. 17). Drilling at the Sandia Pueblo site began April 29, 1998, and the total depth of about 1,320 feet was reached May 31, 1998. The three piezometers at the site are contained in 12-inchdiameter steel surface casing that extends 35 feet below land surface. The configuration of the piezometers is shown in figure 16. Each piezometer consists of 2.5inch-diameter PVC casing, a stainless-steel screen, and a PVC sump. The screened intervals range from about 485 to 525 feet, 1,015 to 1,020 feet, and 1,295 to 1,300 feet below land surface. The geophysical logs were run inside the deep piezometer; therefore, the presence of steel surface casing, stainless-steel screens, sand pack, and bentonite are evident in the logs. Geophysical logs, a completion diagram, and a generalized lithologic diagram of the three piezometers are shown in figure $23 \mathrm{~K}$. Site and construction information and water-level data are listed in table 1.

\section{Rio Bravo Park Site}

The Rio Bravo Park site is located in southwest Albuquerque (fig. 18). Drilling at the Rio Bravo Park site began October 17, 1998, and the total depth of about 603 feet was reached October 22, 1998. The two piezometers at the site are contained in 10-inchdiameter steel surface casing that extends 38 feet below land surface. The configuration of the piezometers is shown in figure 16. Each piezometer consists of 2.5inch-diameter PVC casing, a stainless-steel screen, and a PVC sump. The screened intervals range from about 200 to 205 feet and 585 to 590 feet below land surface. Geophysical logs, a completion diagram, and a generalized lithologic diagram of the two piezometers are shown in figure 23L. Site and construction information and water-level data are listed in table 1.

\section{Westgate Heights Park Site}

The Westgate Heights Park site is located in southwest Albuquerque (fig. 19). Three piezometers were installed at the Westgate Heights Park site. Two of the piezometers are contained in 12-inch-diameter steel surface casing that extends 38 feet below land surface. A third piezometer, installed in a separate borehole approximately 15 feet west of the nested piezometers, is contained in 8-inch-diameter steel surface casing extending 20 feet below land surface. The configuration of the piezometers is shown in figure 20 . Each piezometer consists of 2.5-inch-diameter PVC casing, a stainless-steel screen, and a PVC sump. The screened intervals range from about 320 to 360 feet, 858 to 863 feet, and 1,285 to 1,290 feet below land surface.

Drilling at the nested piezometers location began May 10,2000, and the total depth of about 1,300 feet was reached May 22, 2000. Drilling at the shallow piezometer location began October 26, 2000, and the total depth of about 380 feet was reached October 27 , 2000. Geophysical logs were run in the borehole of the nested piezometers and are shown in figure $23 \mathrm{M}$.

Completion diagrams of the three piezometers also are shown in figure $23 \mathrm{M}$. The generalized lithologic diagram for the shallow piezometer site was constructed from the cuttings of the borehole of the nested piezometers. Site and construction information and water-level data are listed in table 1.

\section{Niese Drive Site}

The Niese Drive site is located in southwest Albuquerque (fig. 21). Drilling at the Niese Drive site began October 30,2000, and the total depth of about 1,480 feet was reached November 10,2000 . The three piezometers at the site are contained in 12-inchdiameter steel surface casing that extends 53 feet below land surface. Later the steel surface casing was cut back to 1.5 feet below land surface and a 3 -foot by 3 -foot galvanized steel vault was set 2 feet in the ground to protect the piezometers from vandalism. The vault is set at ground level and has a three-eighths-inch steelplate top. The configuration of the piezometers is shown in figure 20. Each piezometer consists of 2.5inch-diameter PVC casing, a stainless-steel screen, and a PVC sump. The screened intervals range from about 267 to 287 feet, 950 to 955 feet, and 1,445 to 1,450 feet below land surface. Geophysical logs, a completion diagram, and a generalized lithologic diagram of the three piezometers are shown in figure $23 \mathrm{~N}$. Site and construction information and water-level data are listed in table 1. 


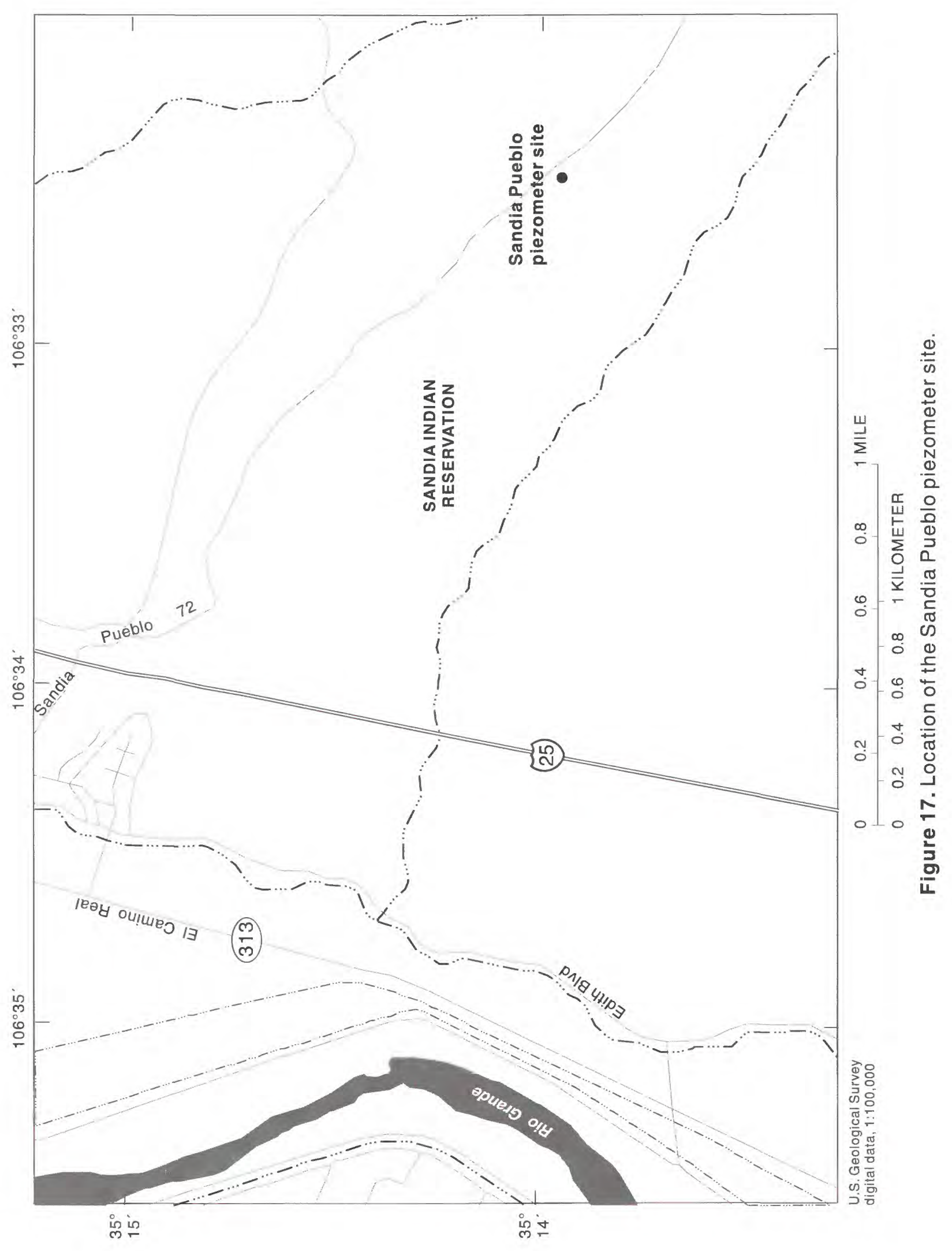




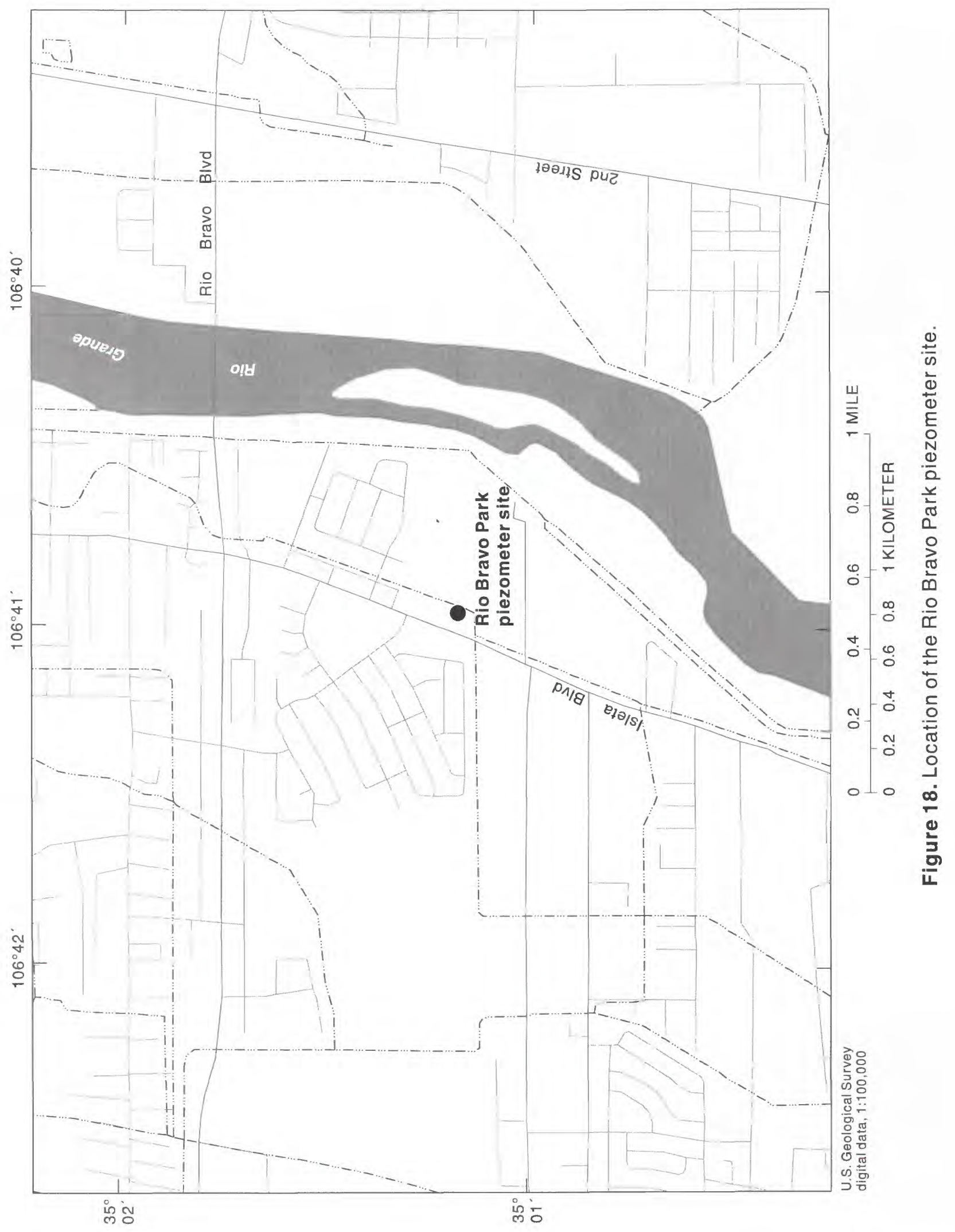




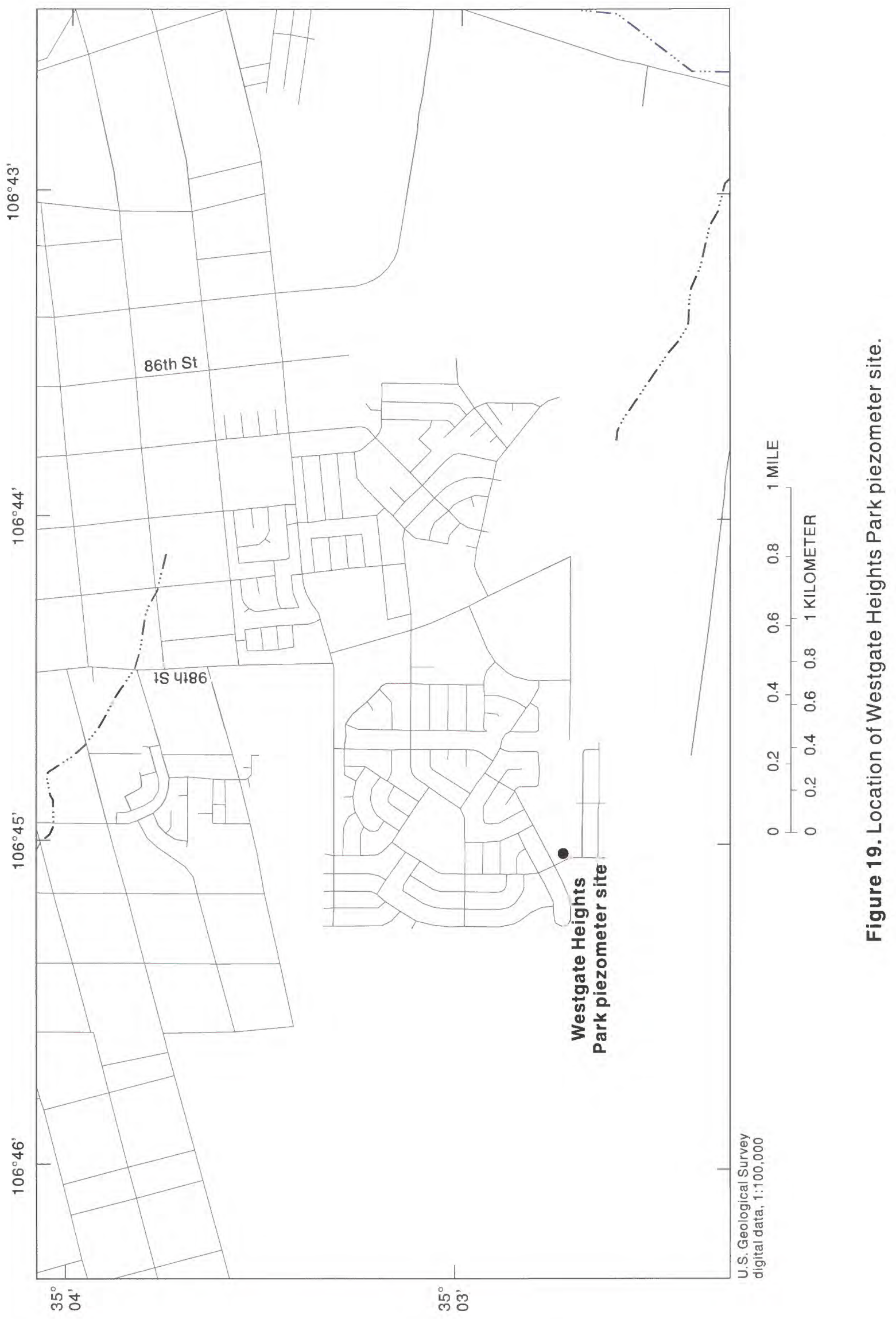




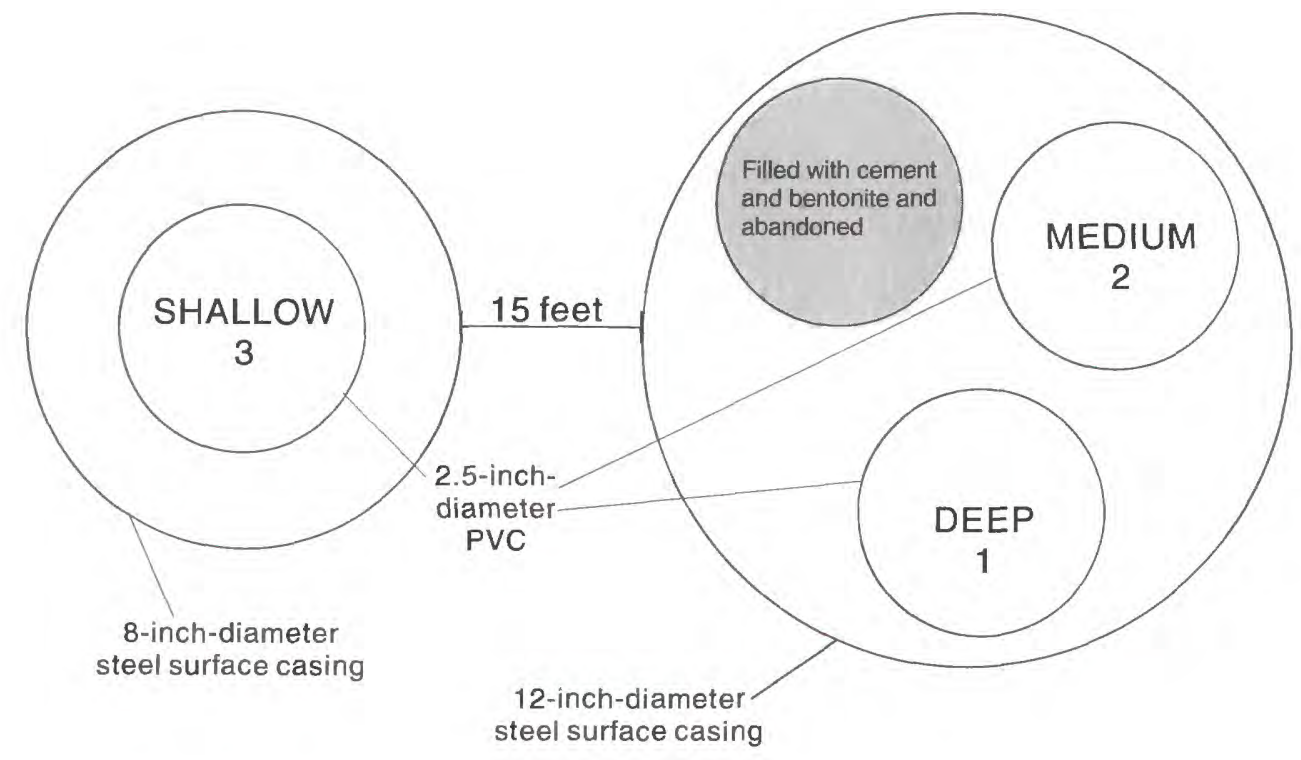

Westgate Heights Park site

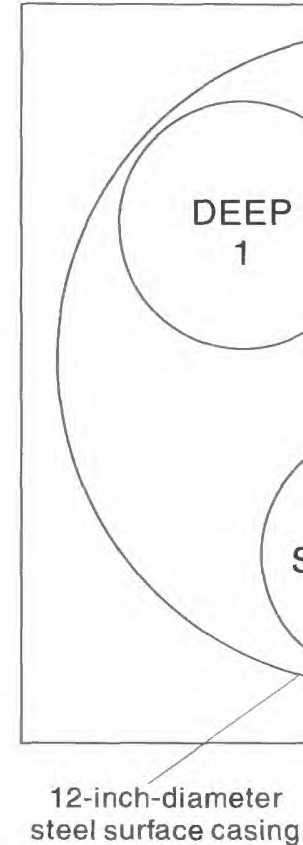

Niese Drive site

steel surface casing 2-inch-

diameter

steel surface

casing

diameter

stainless-

steel casing

Paradise Boulevard site

Not to scale

Figure 20. Configuration of the piezometers at the Westgate Heights Park, Niese Drive, and Paradise Boulevard sites. 


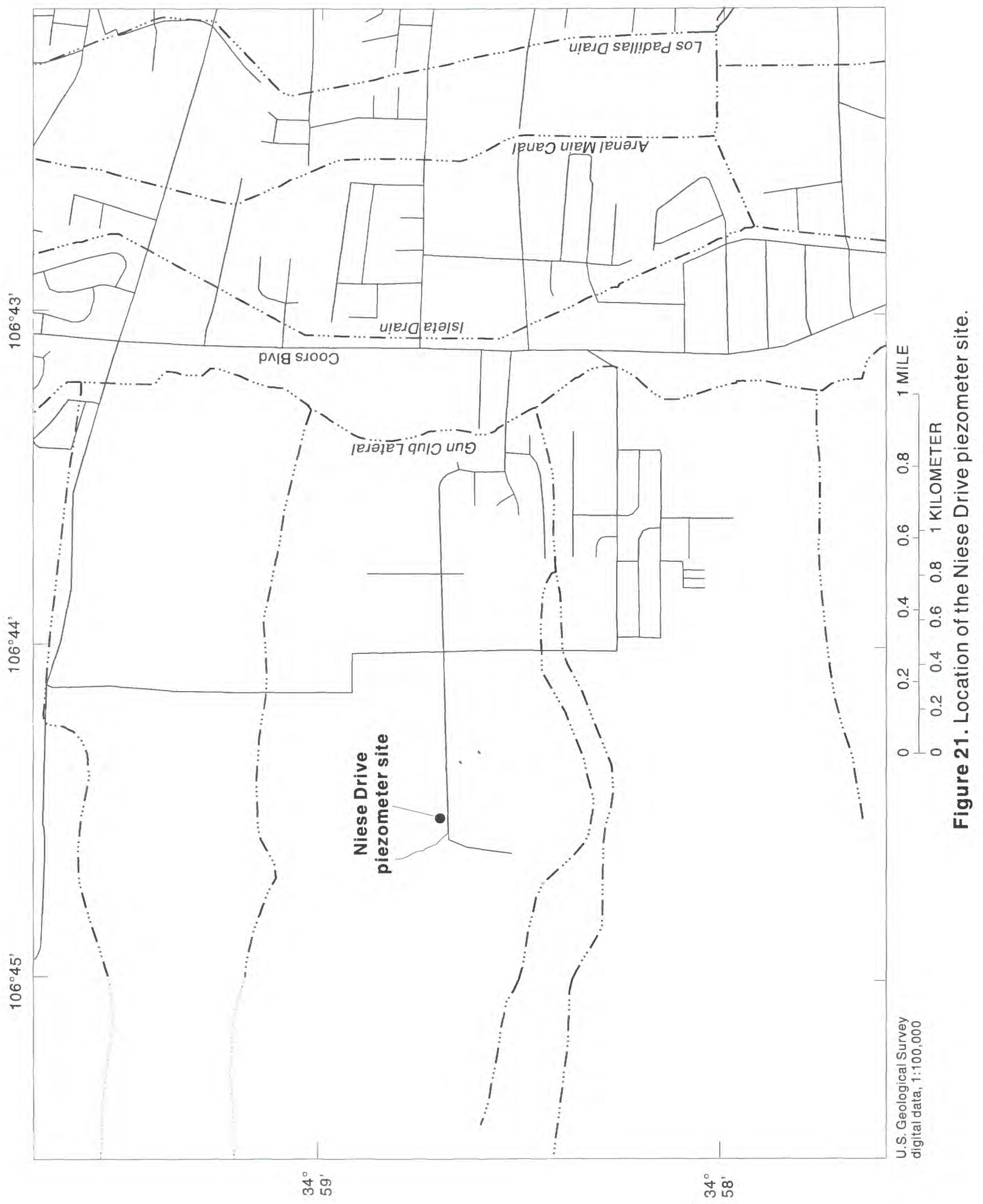




\section{Paradise Boulevard Site}

The Paradise Boulevard site is located in northwest Albuquerque (fig. 22). Drilling at the Paradise Boulevard site began March 15, 2001, and the total depth of about 1,740 feet was reached March 28, 2001. The single piezometer is contained in 8 -inchdiameter steel surface casing that extends 20 feet below land surface. Later the steel surface casing was cut back to 1.5 feet below land surface, and a 3-foot by 3-foot galvanized steel vault was set 2 feet in the ground to protect the piezometer from vandalism. The vault is set at ground level and has a three-eighths-inch steel-plate top (fig. 20). The piezometer consists of 2 -inchdiameter stainless-steel casing, a stainless-steel screen, and a stainless-steel sump. The screened interval ranges from about 1,720 to 1,730 feet below land surface. Geophysical logs, a completion diagram, and a generalized lithologic diagram of the piezometer are shown in figure 23O. Site and construction information and water-level data are listed in table 1.

\section{REFERENCES CITED}

Allen, B.D., Connell, S.D., Heynekamp, M., and Hawley, J.W., 1998, Field log of borehole drilled for installation of nested piezometers, Isleta Boulevard locality: Socorro, New Mexico Bureau of Mines and Mineral Resources Open-File Report 444C, 13 p.

Bartolino, J.R., and Rankin, D.R., 2001, Description of piezometers installed in the Middle Rio Grande Basin area, 1997-99, central New Mexico: U.S. Geological Survey Open-File Report 00-477, 29 p.

Chamberlin, R.M., Allen, B.D., Hawley, J.W., Connell, S.D., and Heynekamp, M., 1999a, Field logs of borehole drilled for nested piezometers, Montesa Park Site: Socorro, New Mexico Bureau of Mines and Mineral Resources Open-File Report 444A, 16 p.

Chamberlin, R.M., Jackson, P., Connell, S.D., Heynekamp, M., and Hawley, J.W., 1999b, Field logs of borehole drilled for nested piezometers, Sierra Vista West Park Site: Socorro, New Mexico Bureau of Mines and Mineral Resources Open-File Report 444B, 30 p.

Connell, S.D., 1998, Field boring log for Sandia Pueblo well, City of Albuquerque piezometer nest, FY1998: Socorro, New Mexico Bureau of Mines and Mineral Resources Open-File Report 444D, 7 p., 3 app.

Jackson, P.B., Connell, S.D., Hawley, J.W., Chamberlin, R.M., and Allen, B.D., 1998, Field logs of boreholes for nested piezometers, Nor Este Park site: Socorro, New Mexico Bureau of Mines and Mineral Resources Open-
File report 444H, 28 p., 1 app., 8 borehole geophysical logs.

Jackson-Paul, P.B., and Connell, S.D., 2001a, Field logs of boreholes for nested piezometers, Rio Bravo Park: Socorro, New Mexico Bureau of Geology and Mineral Resources Open-File Report 444I, 11 p., 2 app.

$2001 \mathrm{~b}$, Preliminary interpretations of the lithostratigraphy, hydrostratigraphy, and borehole geophysics of the Niese Drive well site, Albuquerque, Bernalillo County, New Mexico: Socorro, New Mexico Bureau of Geology and Mineral Resources Open-File Report 444F, 11 p., 2 app.

2001c, Preliminary interpretations of the lithostratigraphy, hydrostratigraphy, and borehole geophysics of the Paradise Road well site: Socorro, New Mexico Bureau of Geology and Mineral Resources Open-File Report 444G, 11 p., 2 app.

2001d, Preliminary interpretations of the lithostratigraphy, hydrostratigraphy, and borehole geophysics of the Westgate Heights Park well site, Albuquerque, New Mexico: Socorro, New Mexico Bureau of Geology and Mineral Resources Open-File Report 444E, 11 p., 2 app.

Johnson, P.S., Connell, S.D., Allred, B., and Allen, B.D., 1996a, Field logs of boreholes for City of Albuquerque piezometer nests, Del Sol Divider, April 1996: Socorro, New Mexico Bureau of Mines and Mineral Resources Open-File Report 426B, 26 p., 1 geophysical log, 1 fig. 1996b, Field logs of boreholes for City of Albuquerque piezometer nests, Garfield Park, September 1996: Socorro, New Mexico Bureau of Mines and Mineral Resources Open-File Report 426A, 23 p., 1 geophysical log, 1 fig.

$1996 \mathrm{c}$, Field logs of boreholes for City of Albuquerque piezometer nests, Hunters Run Park Park, May 1996: Socorro, New Mexico Bureau of Mines and Mineral Resources Open-File Report 426C, 25 p., 1 geophysical $\log , 1 \mathrm{fig}$

1996d, Field logs of boreholes for City of Albuquerque piezometer nests, Sister Cities Park, March 1996: Socorro, New Mexico Bureau of Mines and Mineral Resources Open-File Report 426A, 23 p., 1 geophysical log, 1 fig.

1996e, Field logs of boreholes for City of Albuquerque piezometer nests, West Bluff Park, July 1996: Socorro, New Mexico Bureau of Geology and Mineral Resources Open-File Report 426D, 19 p., 1 geophysical log, 1 fig.

Stone, B.D., Allen, B.D., Mikolas, M., Hawley, J.W., Haneberg, W.C., Johnson, P.S., Allred, B., and Thorn, C.R., 1998, Preliminary lithostratigraphy, interpreted geophysical logs, and hydrogeologic characteristics of the 98th Street core hole, Albuquerque, New Mexico: U.S. Geological Survey Open-File Report 98-210, 82 p. 


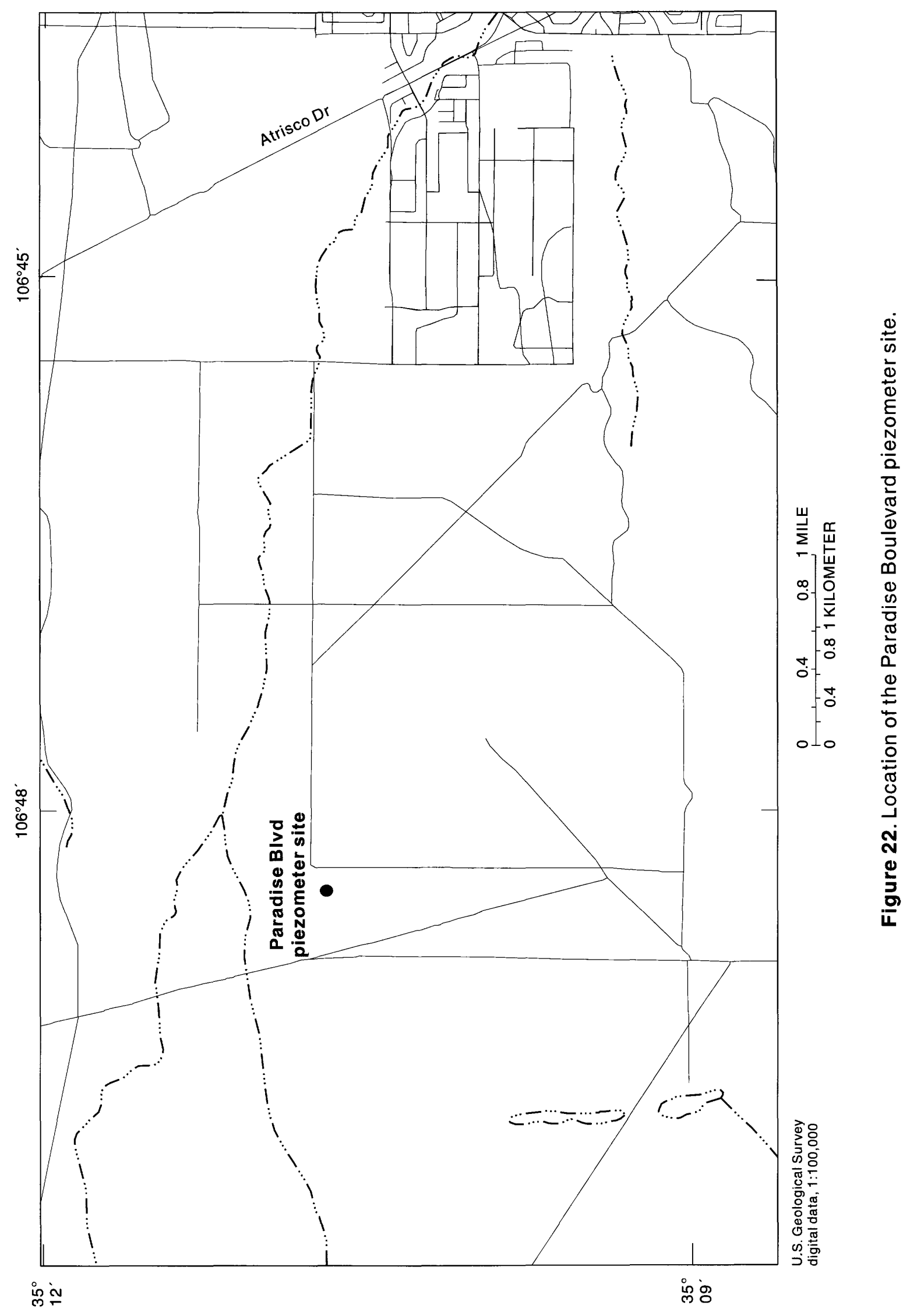


GEOPHYSICAL LOGS, PIEZOMETER COMPLETIONS, AND GENERALIZED LITHOLOGIC DIAGRAMS 
16-inch (16N)

and 64 -inch $(64 \mathrm{~N})$

resistivity logs

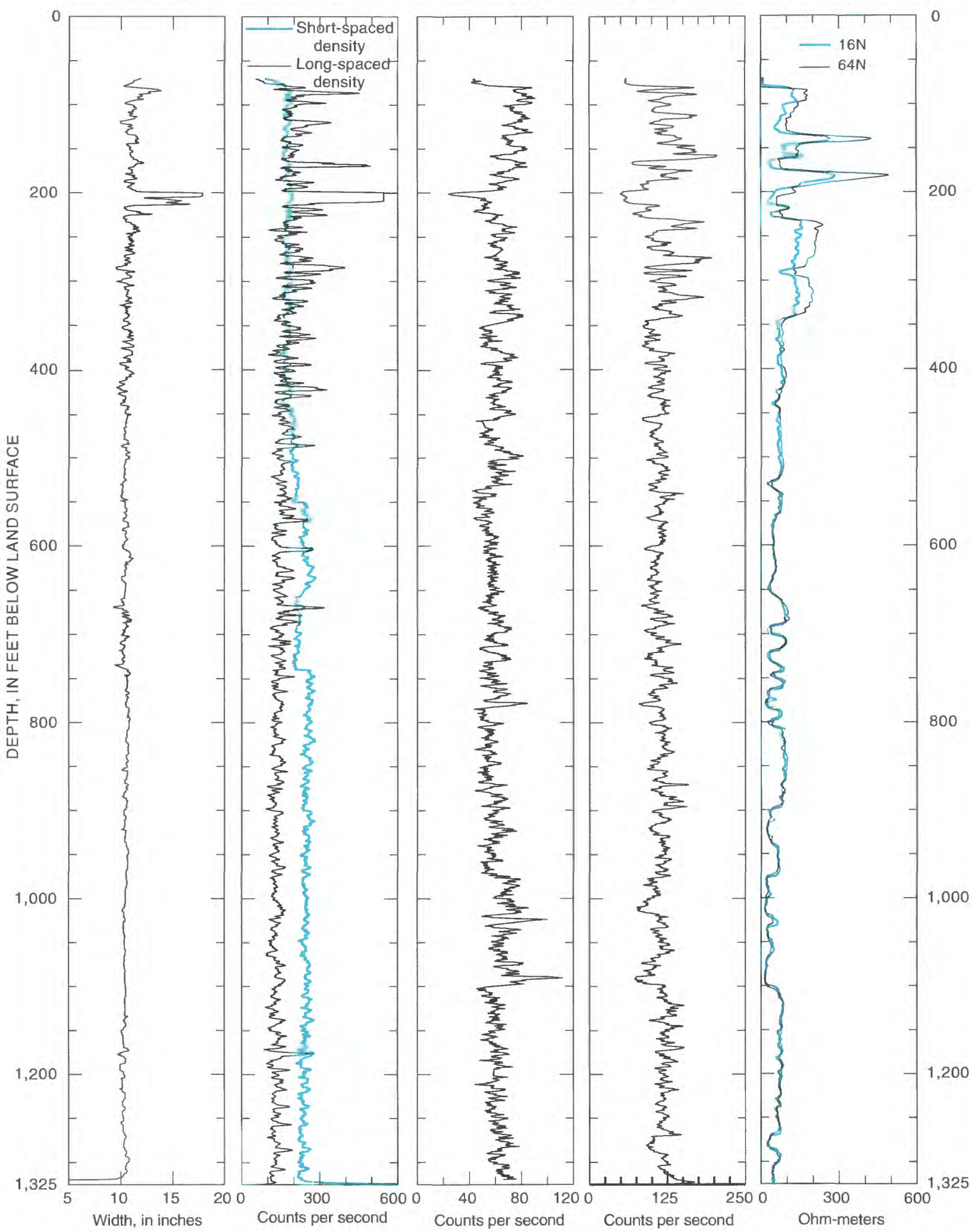

Figure 23A. Geophysical logs, piezometer completion, and generalized lithologic diagram for the Sister Cities Park site (lithologic information from Johnson and others, 1996d). 


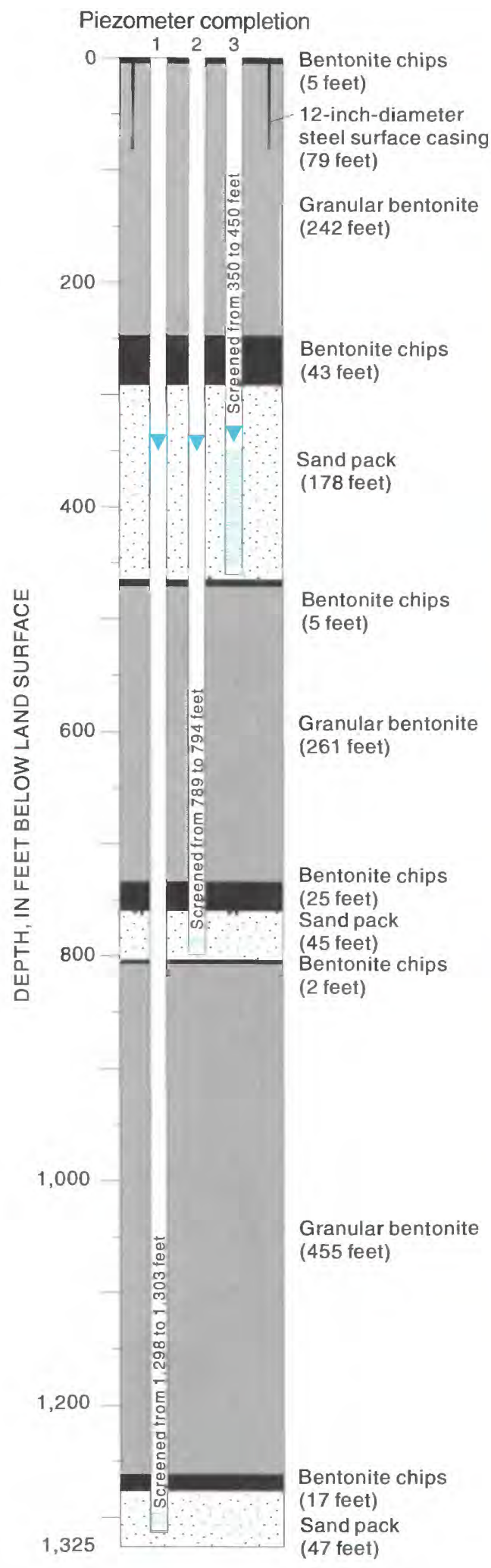

Lithology

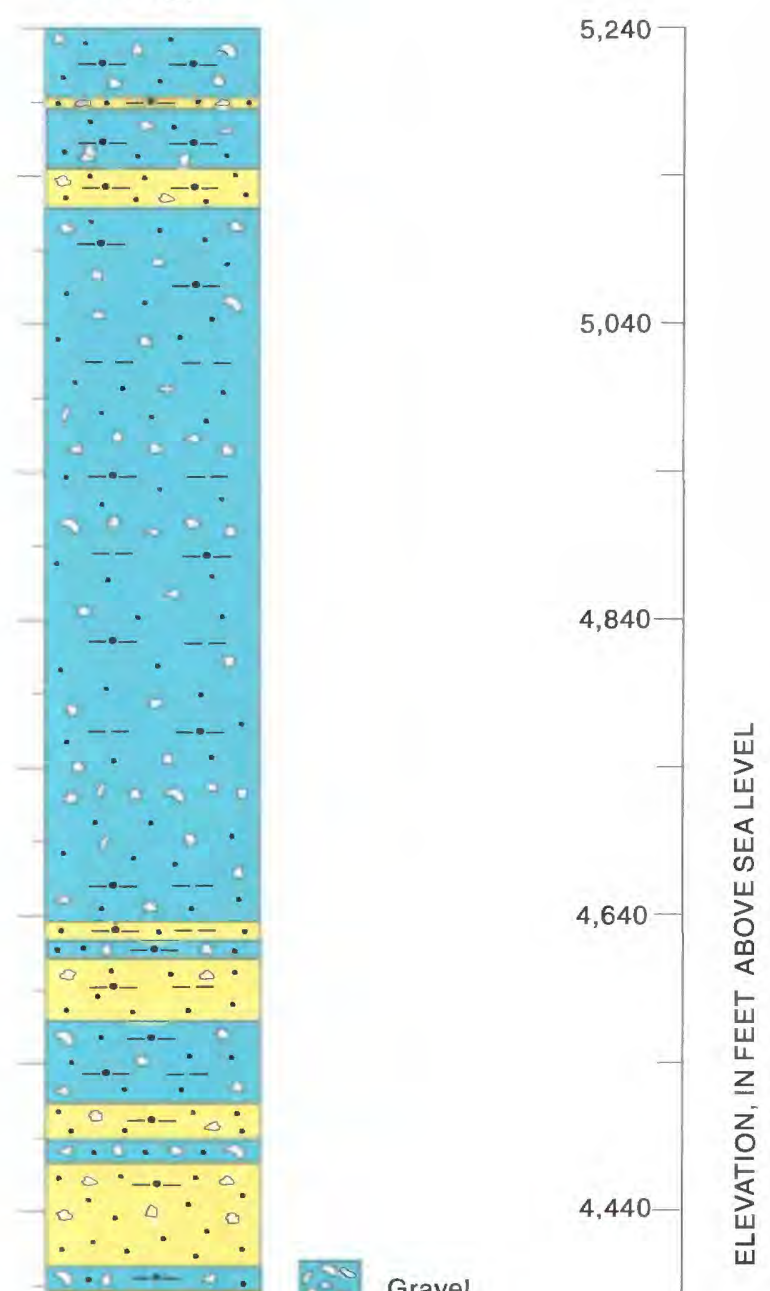

Figure 23A. Geophysical logs, piezometer completion, and generalized lithologic diagram for the Sister Cities Park site (lithologic information from Johnson and others, 1996d)-Concluded. 


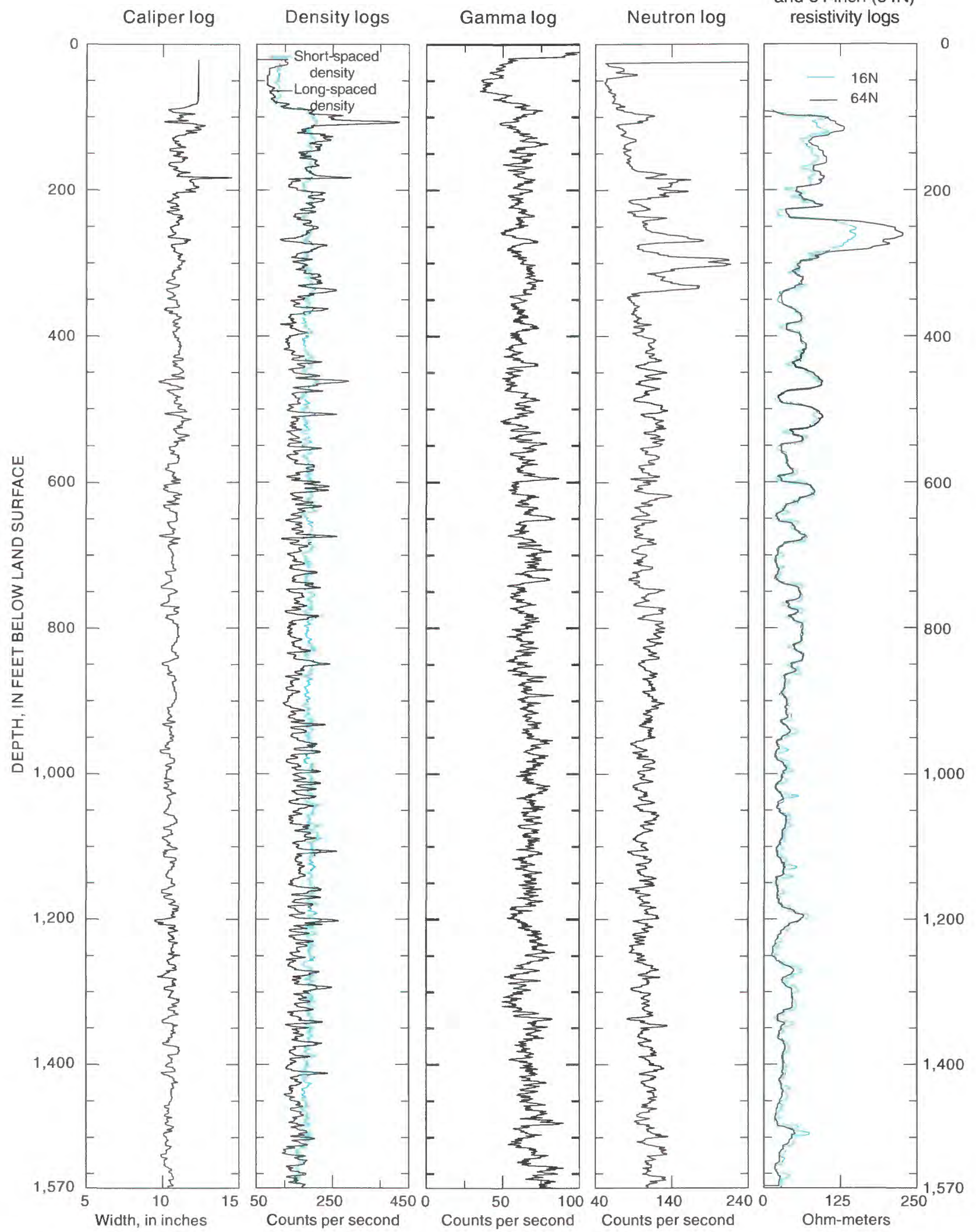

Figure 23B. Geophysical logs, piezometer completion, and generalized lithologic diagram for the Del Sol Divider Park site (lithologic information from Johnson and others, 1996a). 


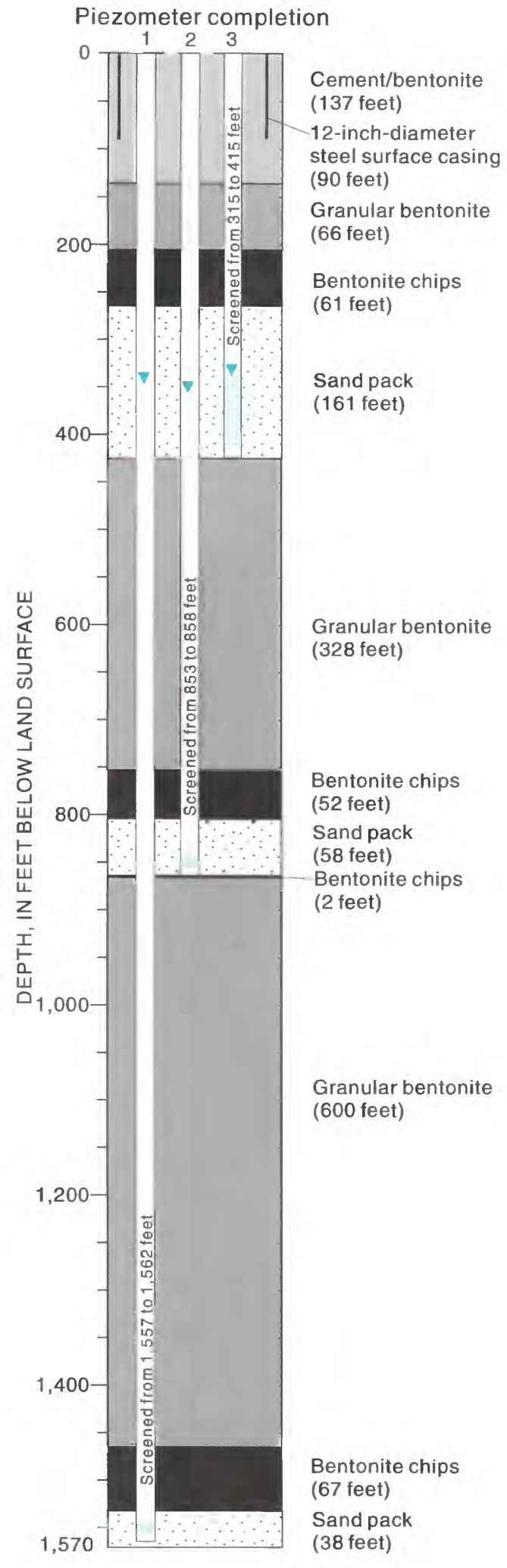

Lithology
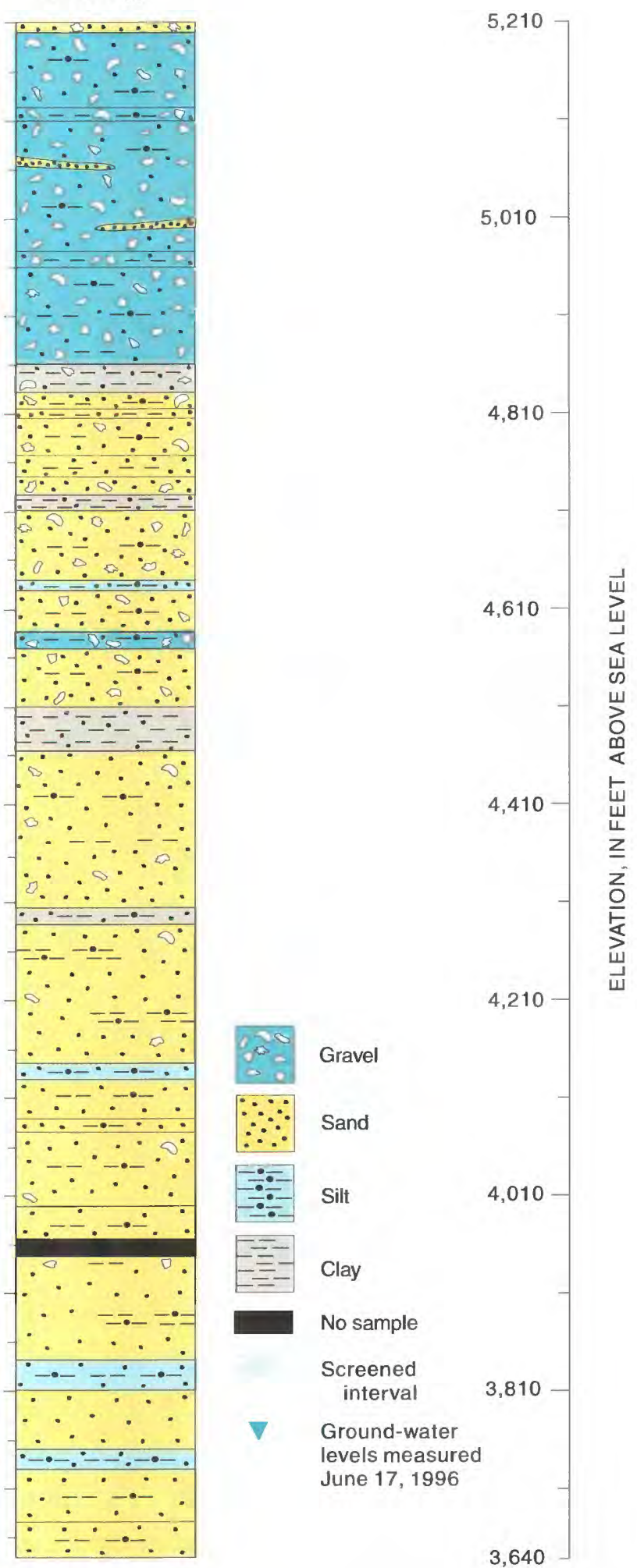

Figure 23B. Geophysical logs, piezometer completion, and generalized lithologic diagram for the Del Sol Divider Park site (lithologic information from Johnson and others, 1996b)--Concluded. 
-inch (16N)

and 64 -inch $(64 \mathrm{~N})$

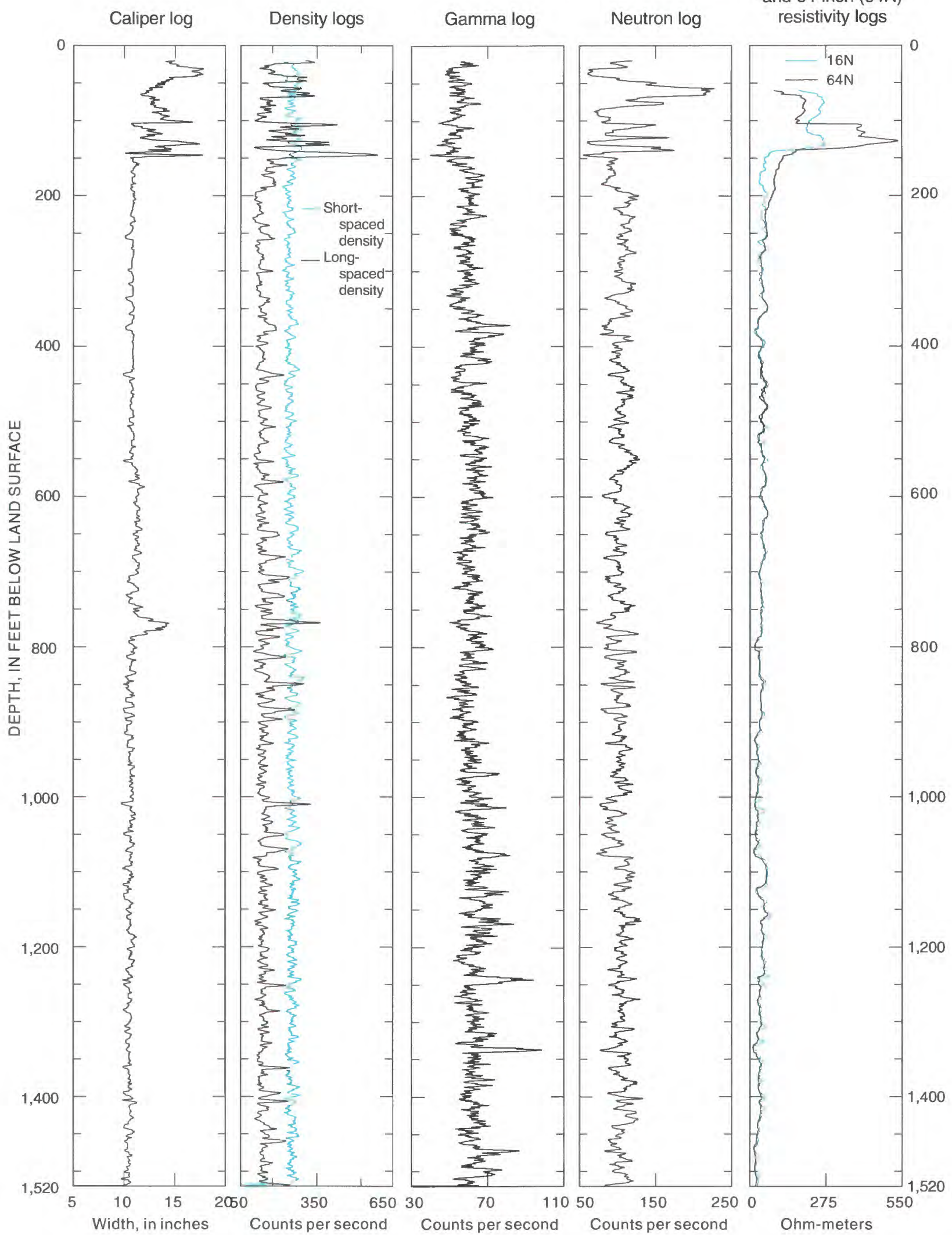

Figure 23C. Geophysical logs, piezometer completion, and generalized lithologic diagram for the Hunters Run Park site (lithologic information from Johnson and others, 1996c). 


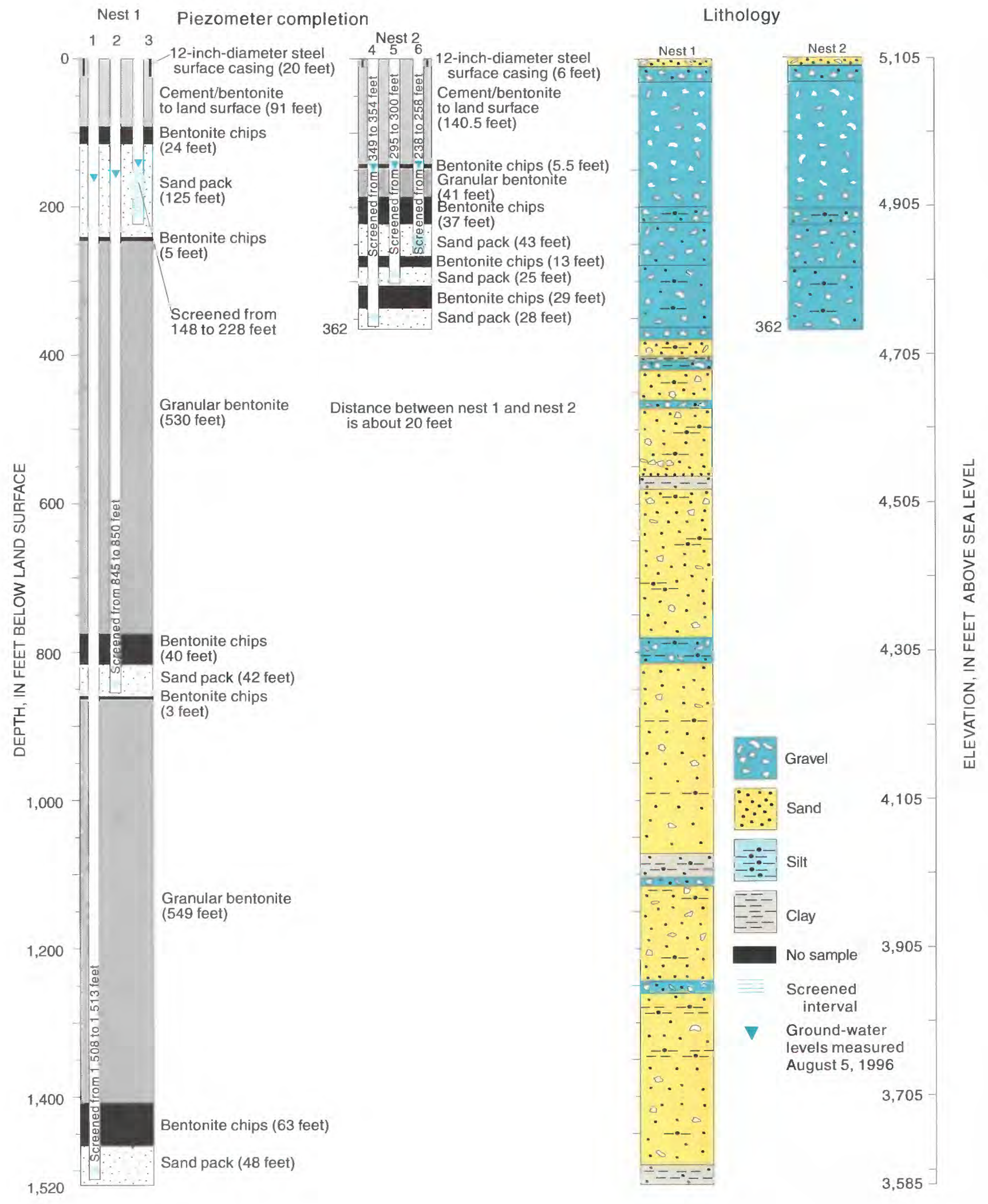

Figure 23C. Geophysical logs, piezometer completion, and generalized lithologic diagram for the Hunters Run Park site (lithologic information from Johnson and others, 1996c)-Concluded. 


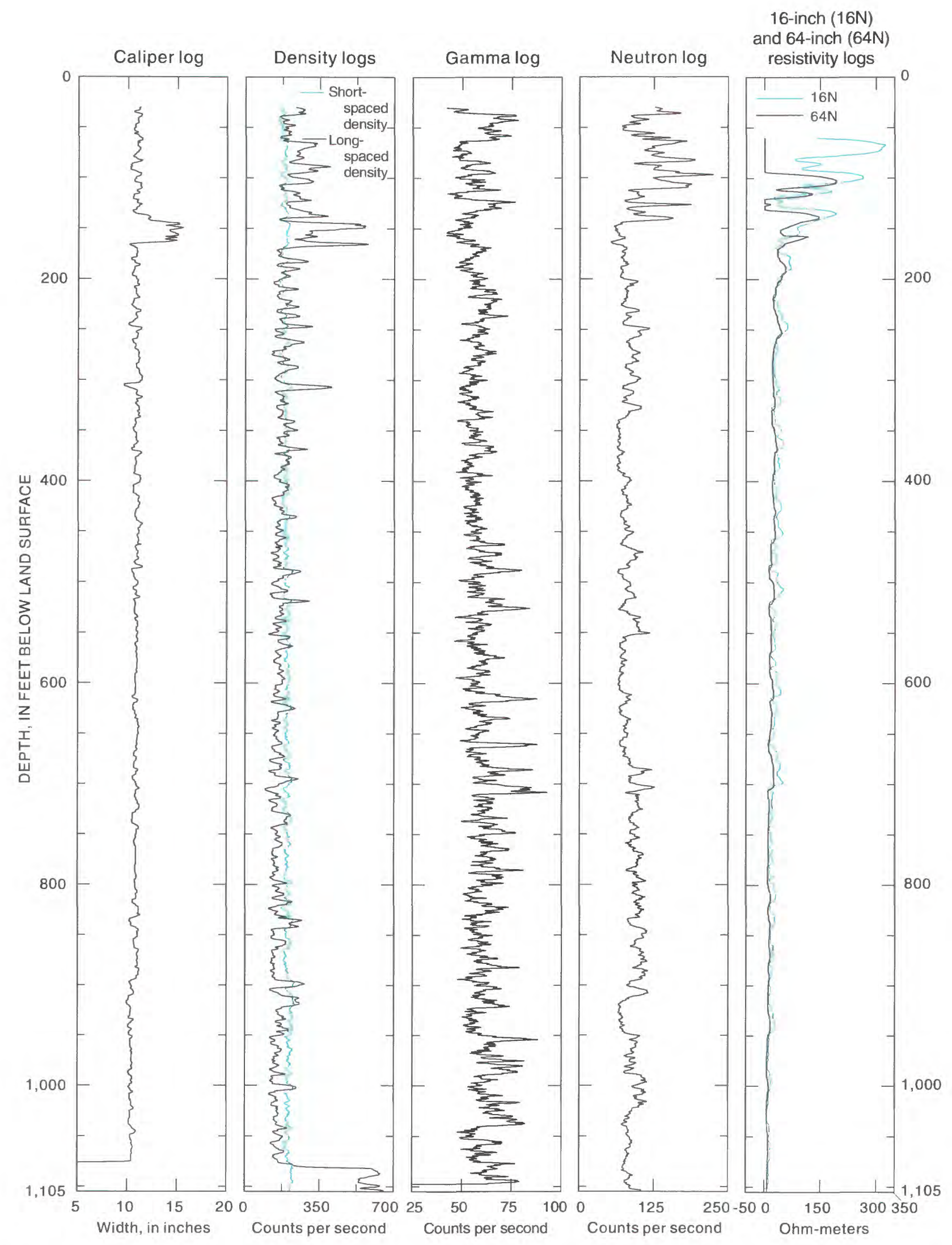

Figure 23D. Geophysical logs, piezometer completion, and generalized lithologic diagram for the West Bluff Park site (lithologic information from Johnson and others, 1996e). 


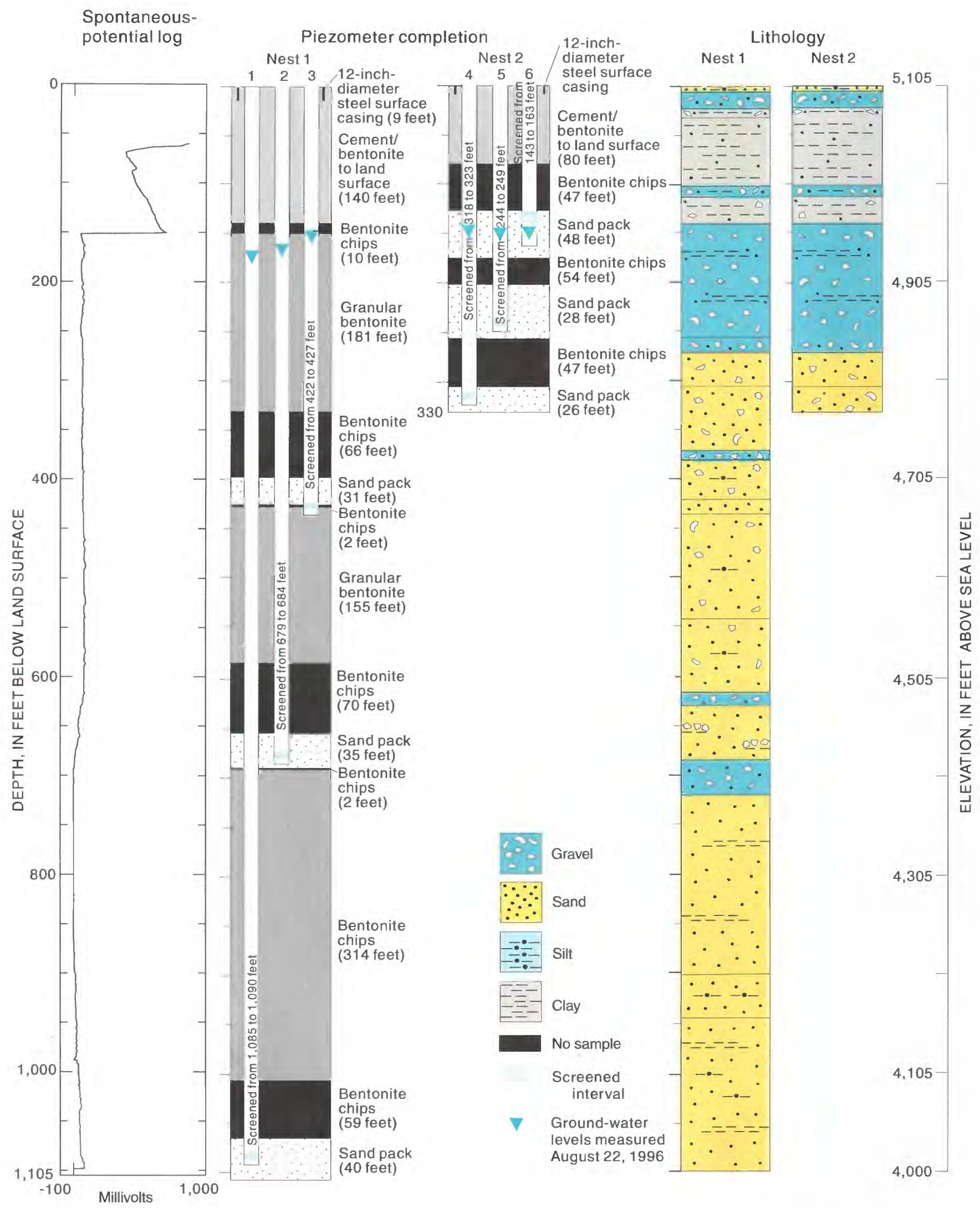

Figure 23D. Geophysical logs, piezometer completion, and generalized lithologic diagram for the West Bluff Park site (lithologic information from Johnson and others, 1996e)--Concluded. 


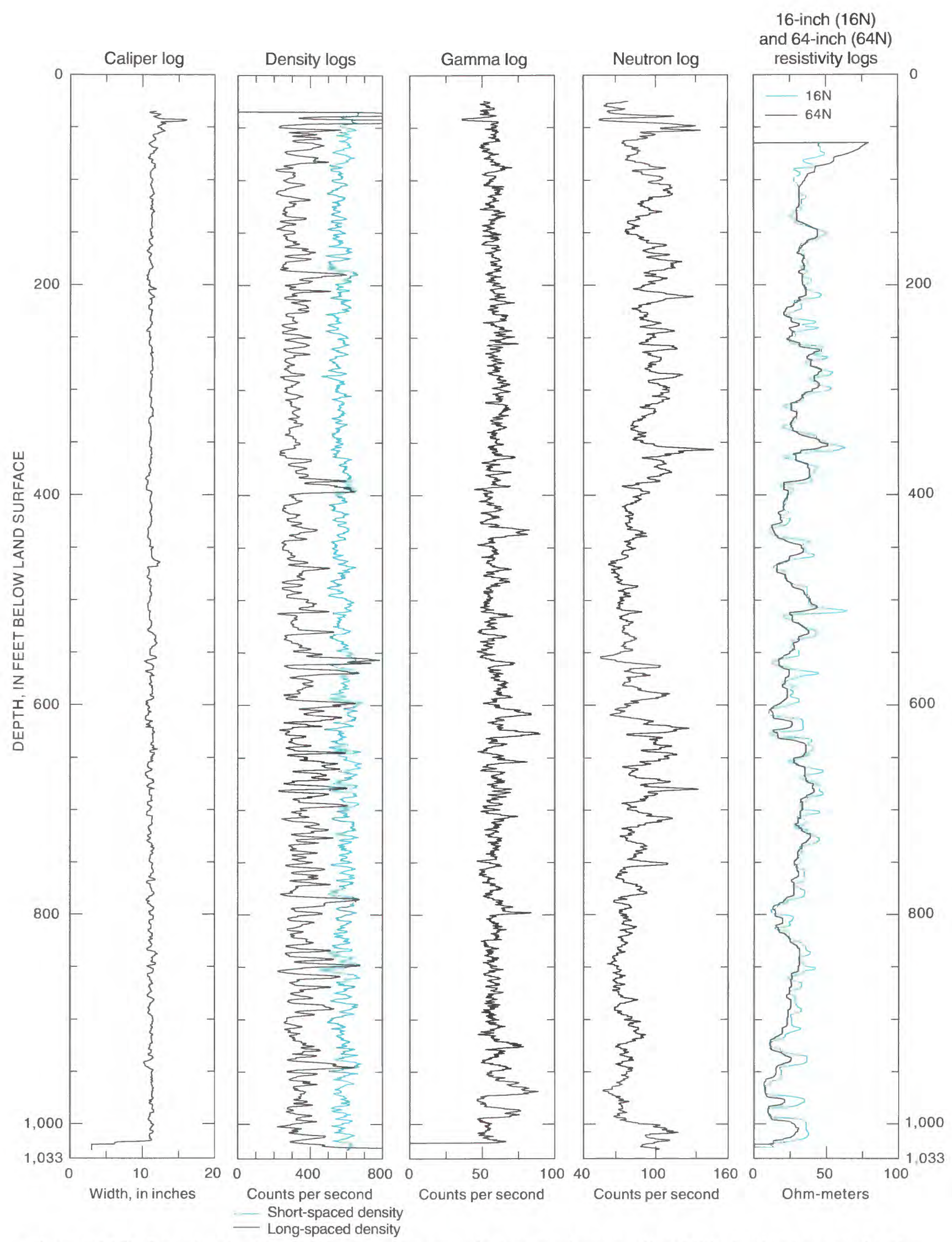

Figure 23E. Geophysical logs, piezometer completion, and generalized lithologic diagram for the Garfield Park site (lithologic information from Johnson and others, 1996b). 

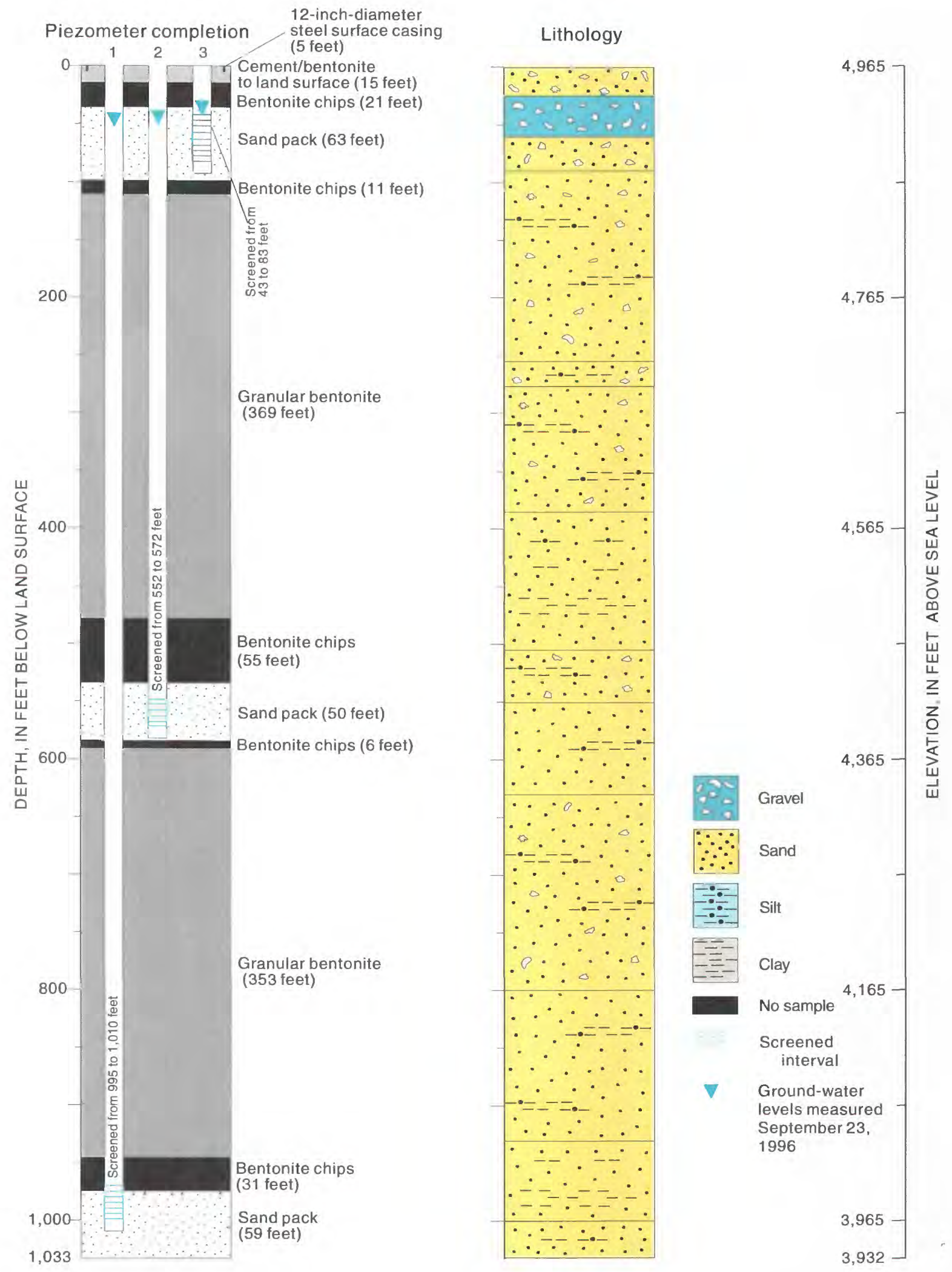

Figure 23E. Geophysical logs, piezometer completion, and generalized lithologic diagram for the Garfield Park site (lithologic information from Johnson and others, 1996b)-Concluded. 


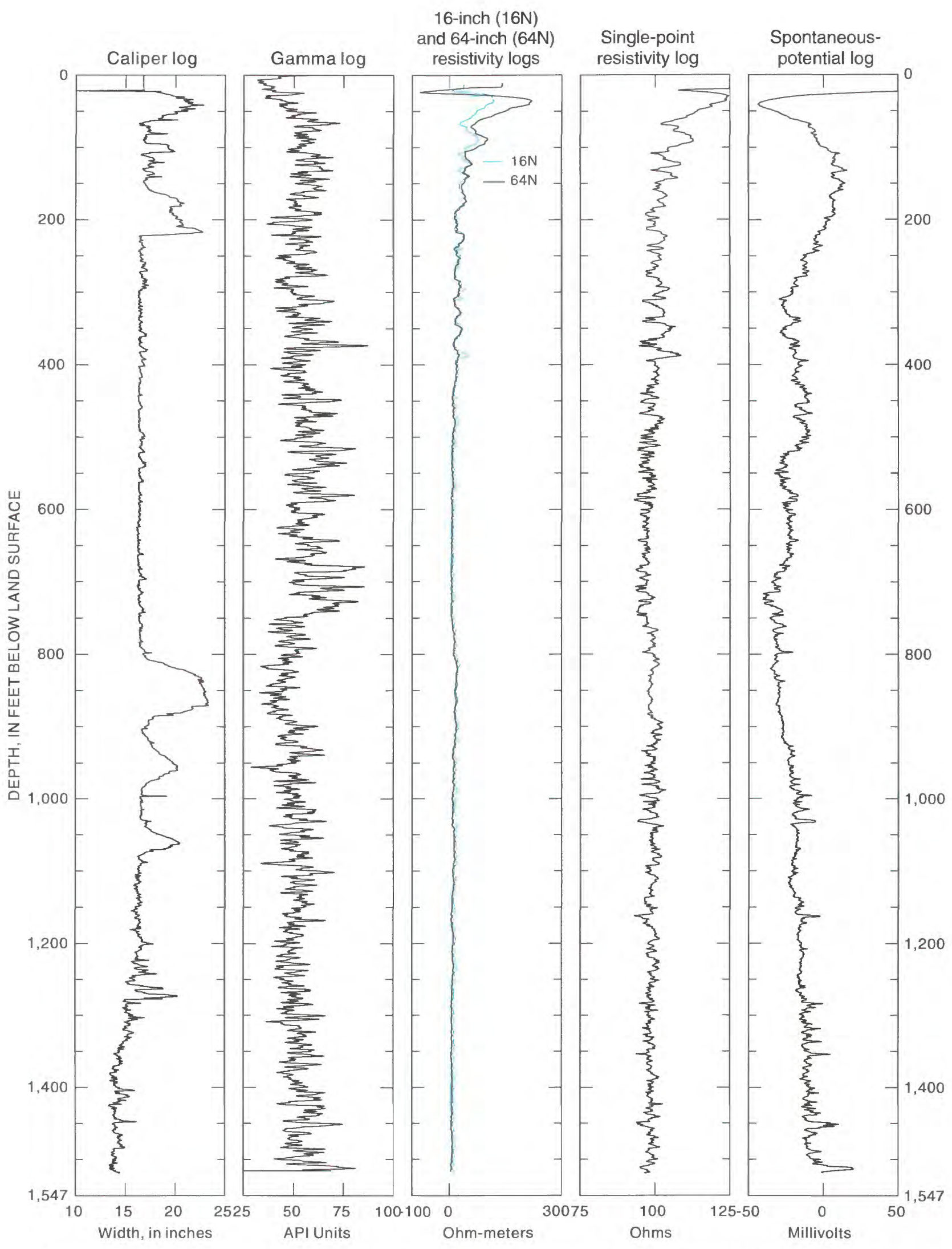

Figure 23F. Geophysical logs, piezometer completion, and generalized lithologic diagram for the 98th Street site (lithologic information from Stone and others, 1998). 

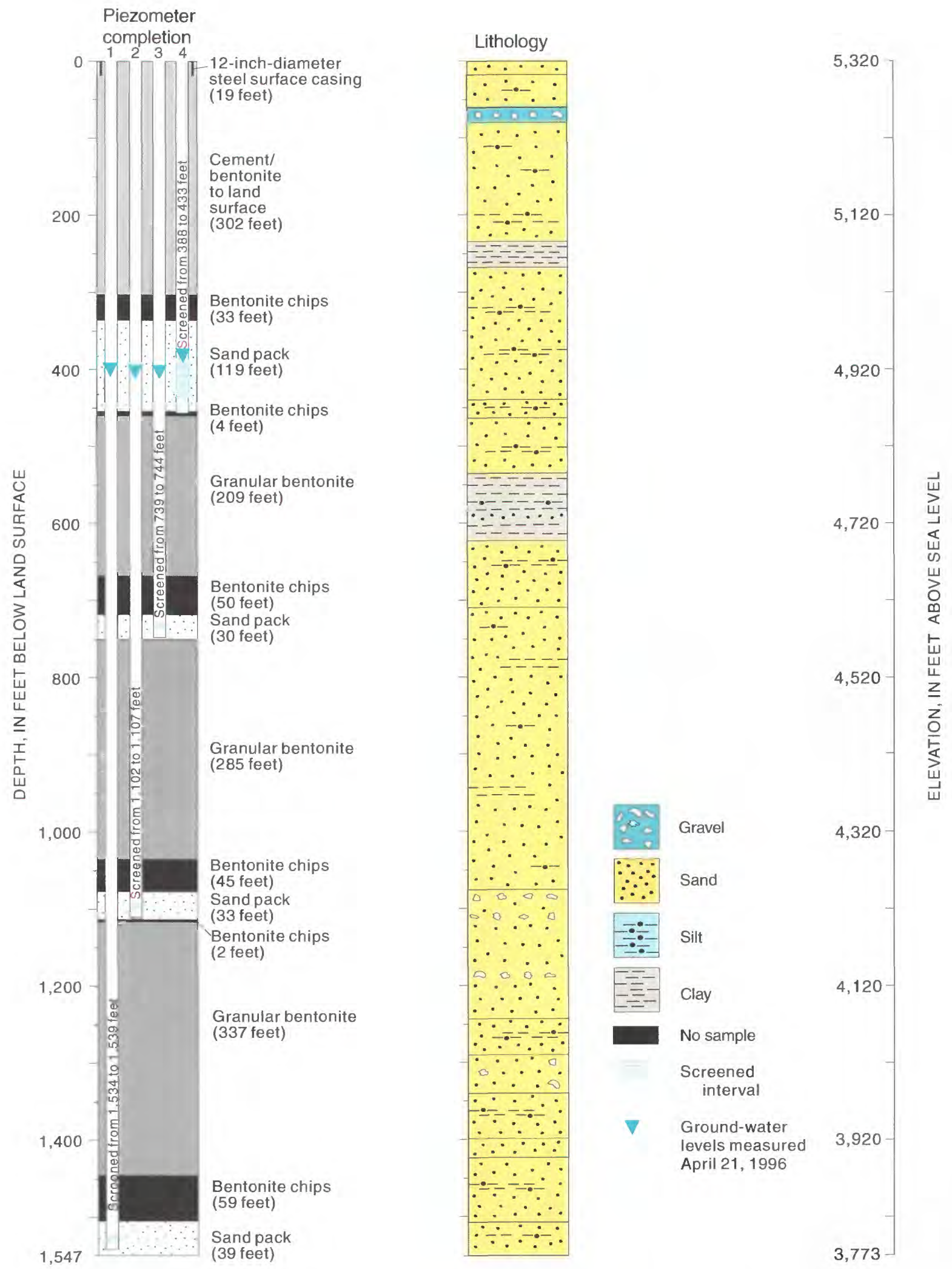

Figure 23F. Geophysical logs, piezometer completion, and generalized lithologic diagram for the 98th Street site (lithologic information from Stone and others, 1998)--Concluded. 

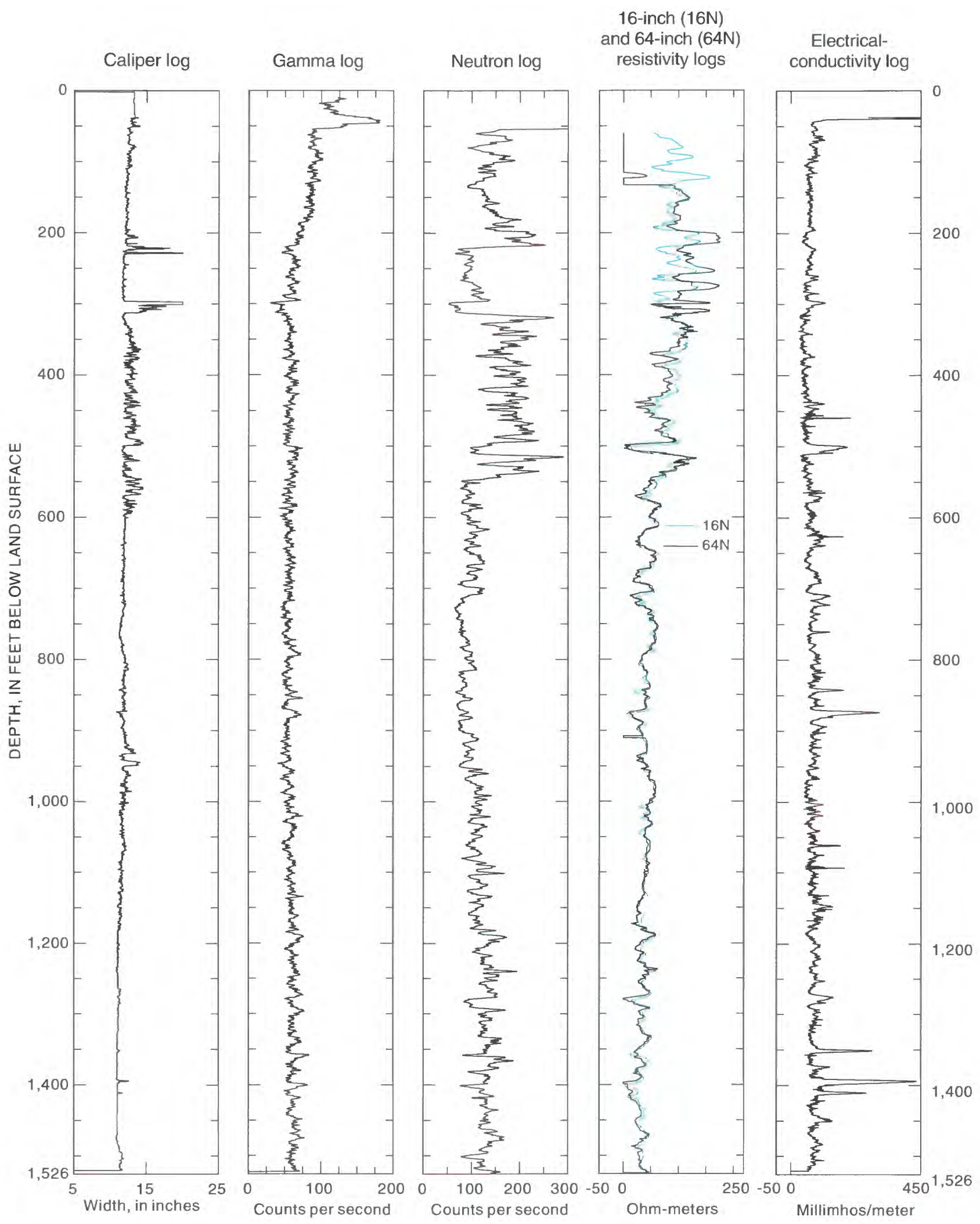

Figure 23G. Geophysical logs, piezometer completion, and generalized lithologic diagram for the Nor Este Park site (lithologic information from Jackson and others, 1998). 


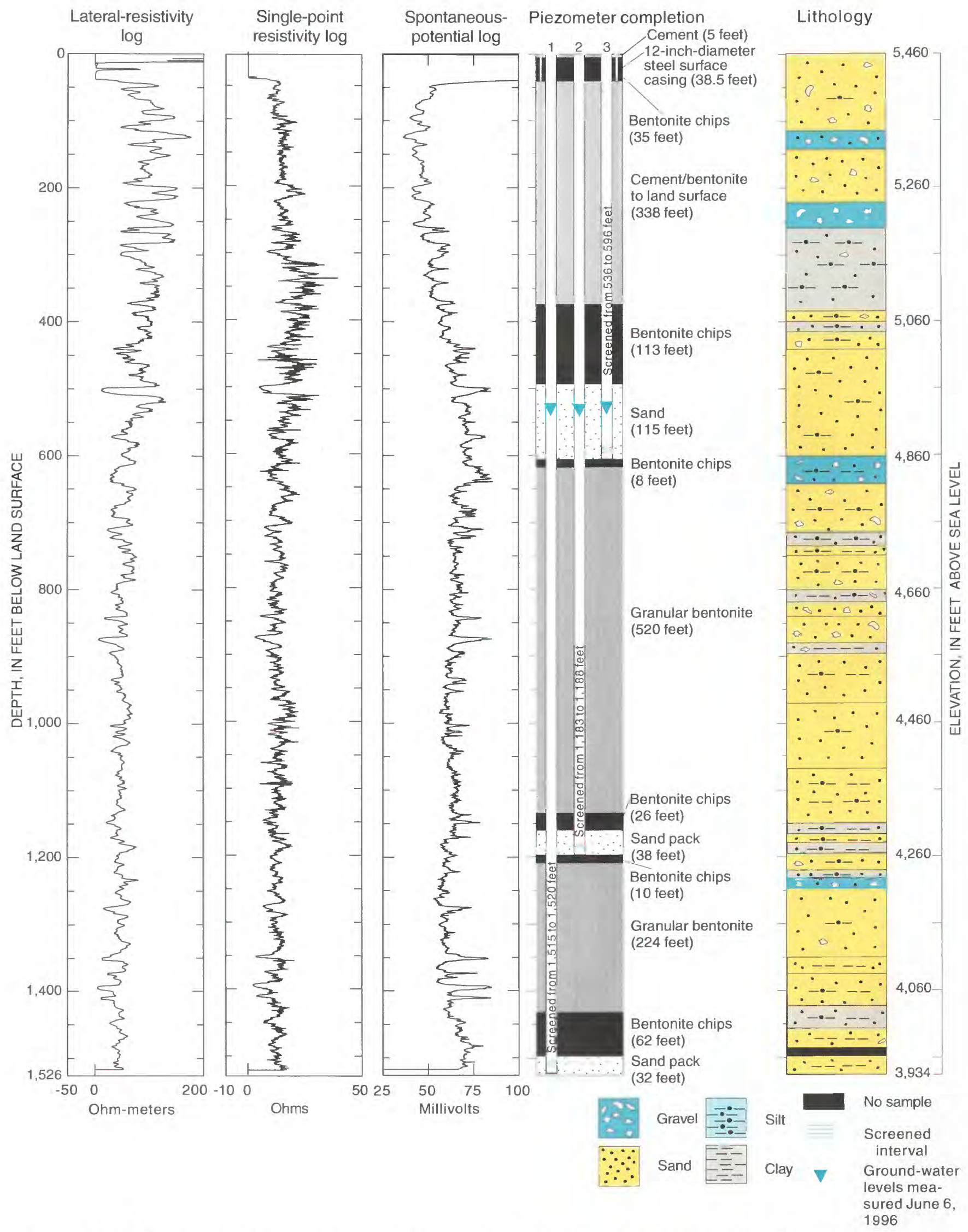

Figure 23G. Geophysical logs, piezometer completion, and generalized lithologic diagram for the Nor Este Park site (lithologic information from Jackson and others, 1998)--Concluded. 

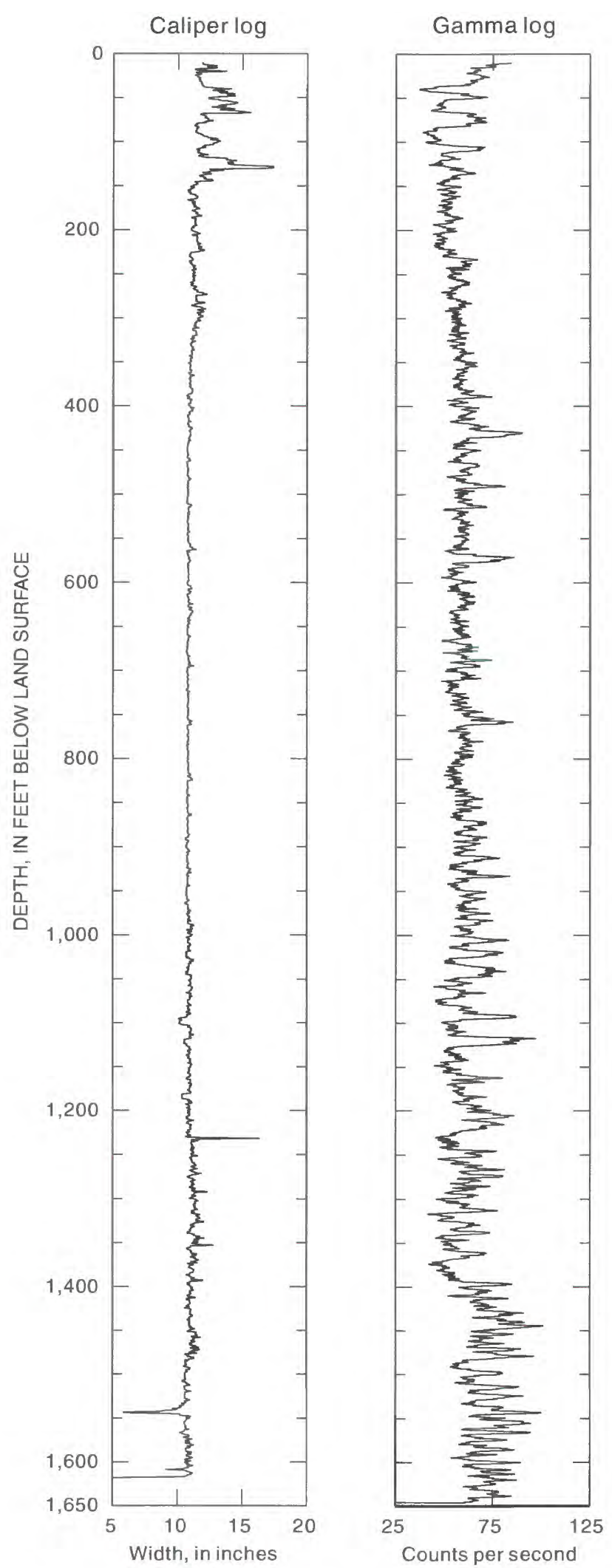

Neutron log

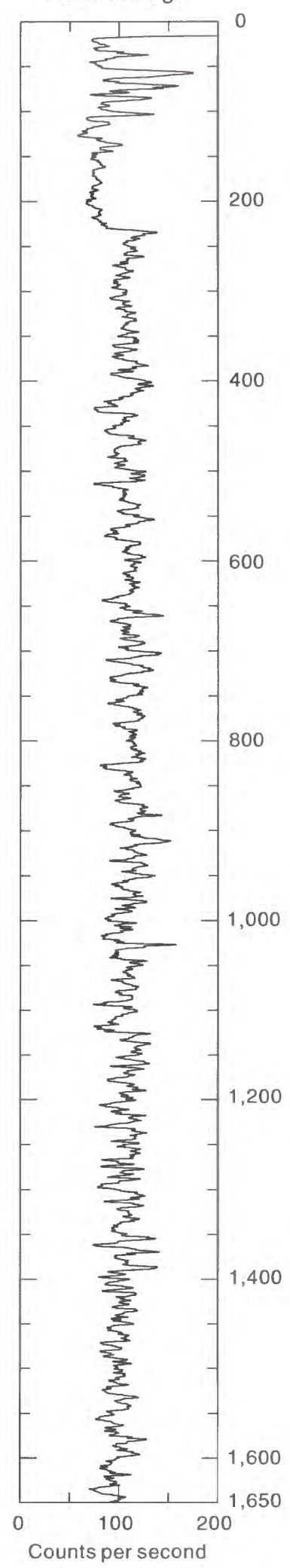

Figure 23H. Geophysical logs, piezometer completion, and generalized lithologic diagram for the Sierra Vista Complex site (lithologic information from Chamberlin and others, 1999b). 

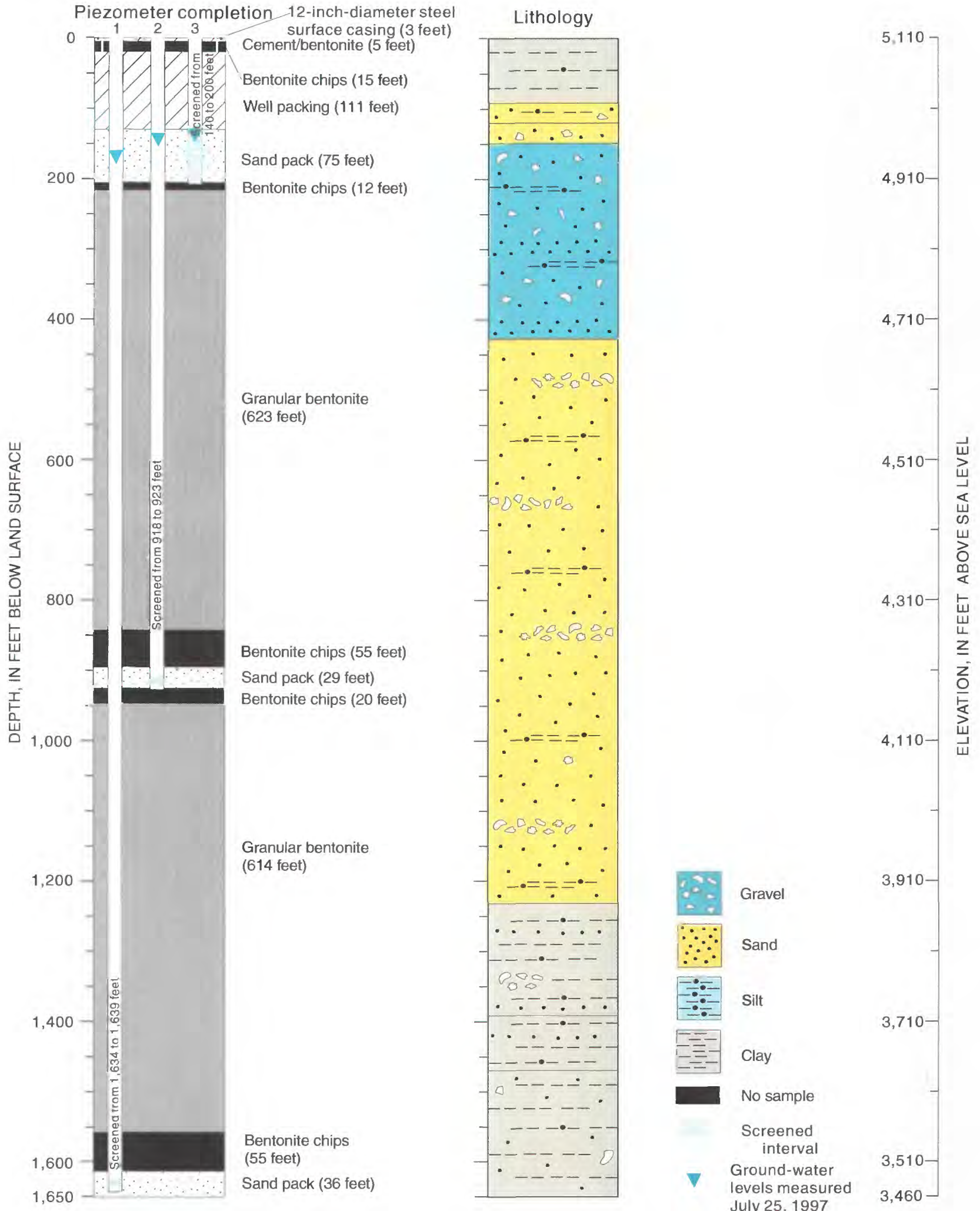

Figure 23H. Geophysical logs, piezometer completion, and generalized lithologic diagram for the Sierra Vista Complex site (lithologic information from Chamberlin and others, 1999b)--Concluded. 


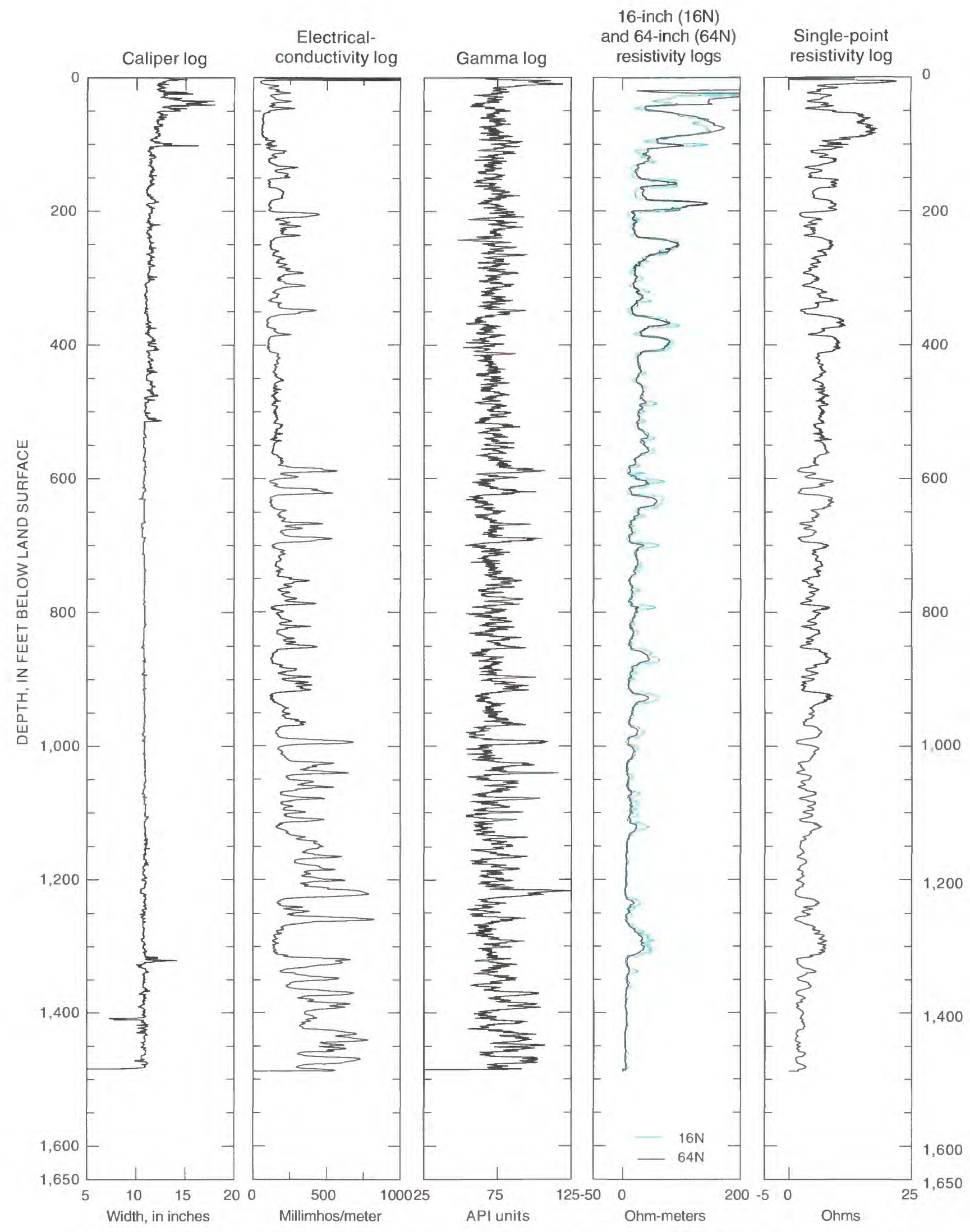

Figure 23l. Geophysical logs, piezometer completion, and generalized lithologic diagram for the Montesa Park site (lithologic information from Chamberlin and others, 1999a). 
potential log

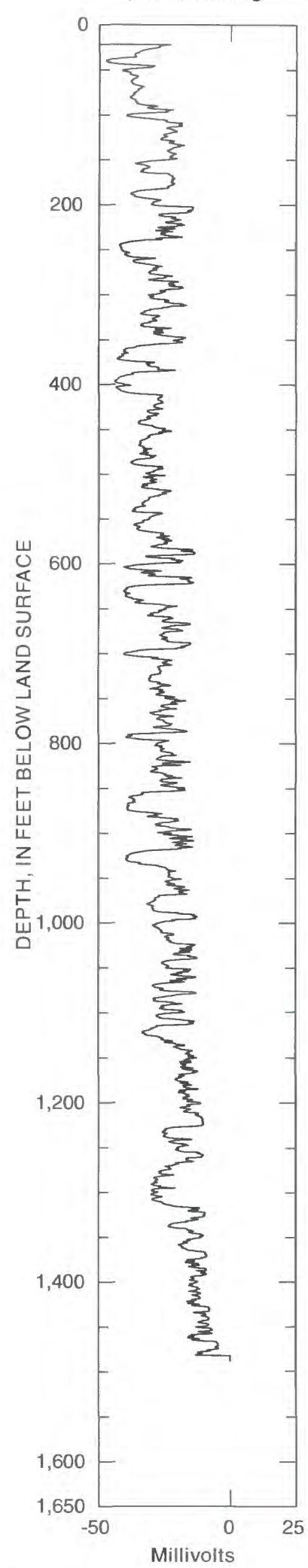

Piezometer completion

${ }^{1} 22^{3}$-12-inch-diameter steel surface casing (3 feet)

Cement/bentonite

to land surface

(197 feet)

Bentonite chips

(15 feet)

Sand pack

(120 feet)

Bentonite chips

(8 feet)

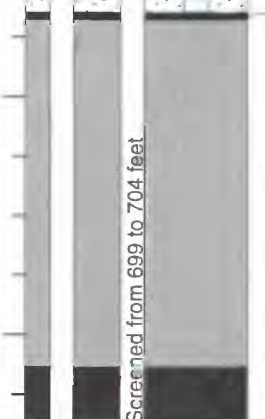

Granular bentonite (288 feet)

Bentonite chips

(47 feet)

Sand pack (34 feet)

-Bentonite chips

(9 feet)

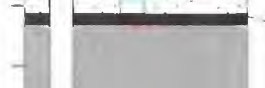

(1)

Granular bentonite

(819 feet)

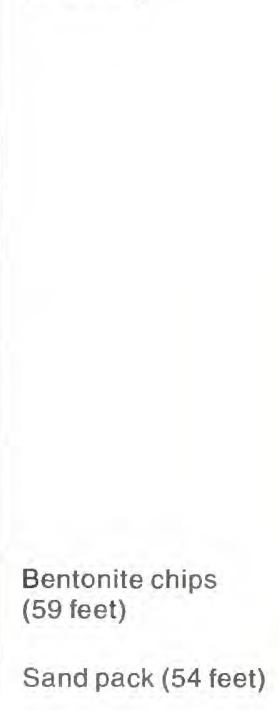

Lithology

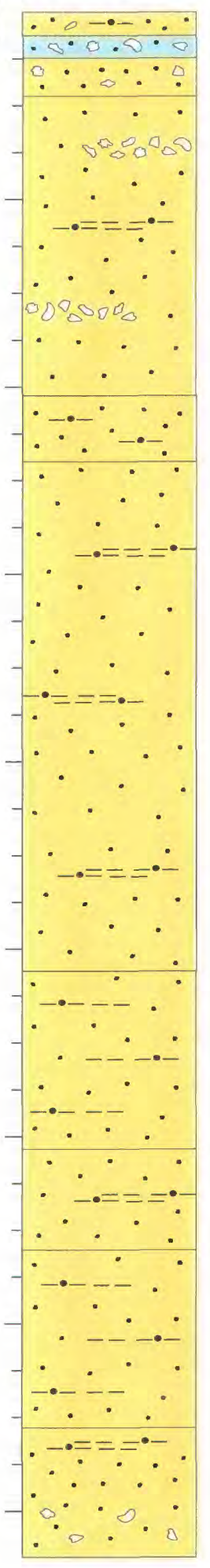

5,100

4,900

4,700

4,500

岃

4,300

4,100

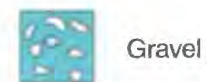

$\because \because$ Sand

$\therefore \quad 3,900$

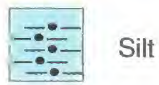

EE- Clay

No sample

3,700

Screened interval

Ground-water

levels measured

September 17,1997

$\left.\begin{array}{l}3,500 \\ 3,450\end{array}\right]$

Figure 23I. Geophysical logs, piezometer completion, and generalized lithologic diagram for the Montesa Park site (lithologic information from Chamberlin and others, 1999a)--Concluded. 

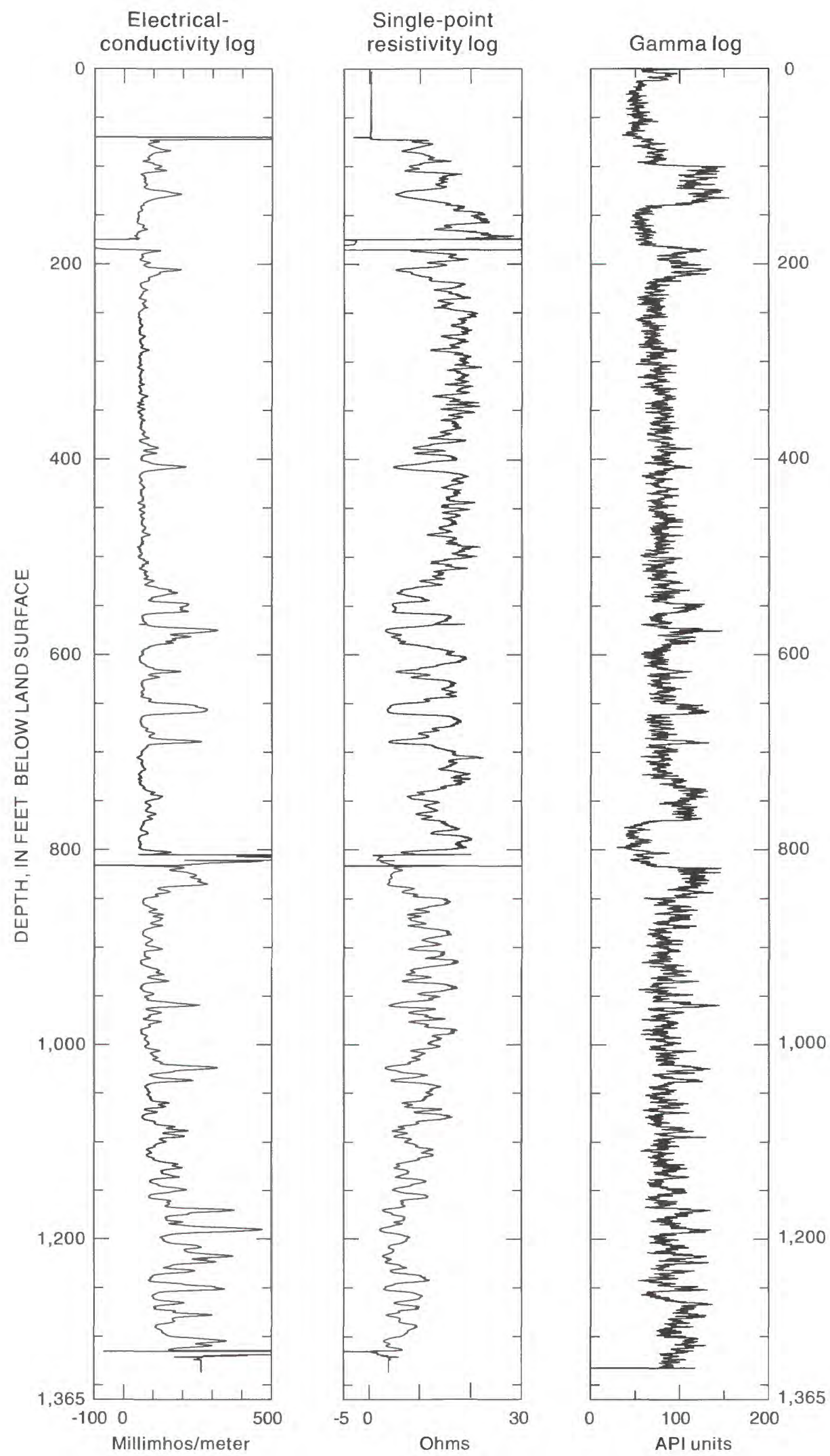

Figure 23J. Geophysical logs, piezometer completion, and generalized lithologic diagram for the Isleta Boulevard site (lithologic information from Allen and others, 1998). 


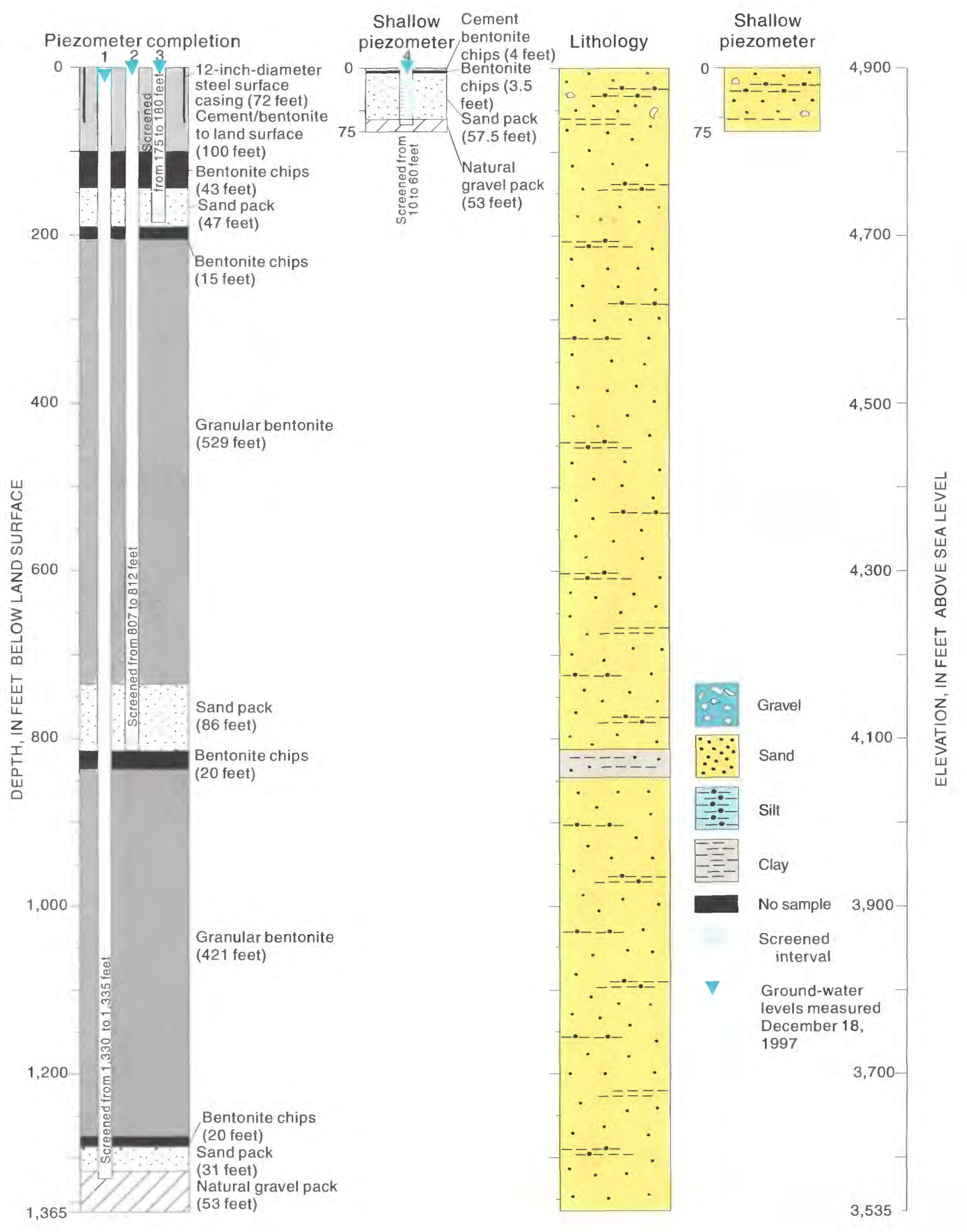

Figure 23J. Geophysical logs, piezometer completion, and generalized lithologic diagram for the Isleta Boulevard site (lithologic information from Allen and others, 1998)--Concluded. 


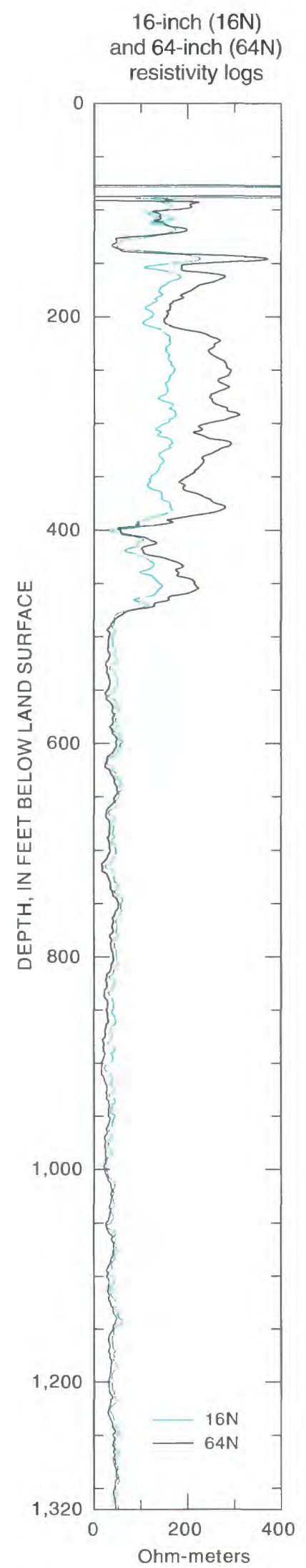

Single-point resistivity log

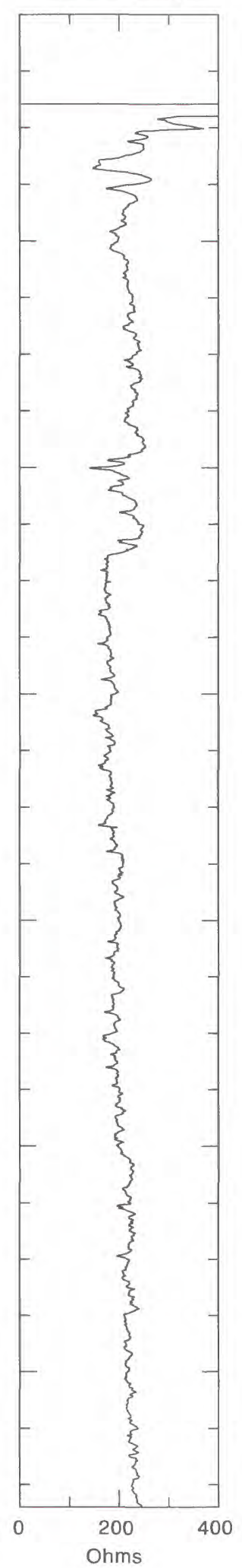

Spontaneouspotential log

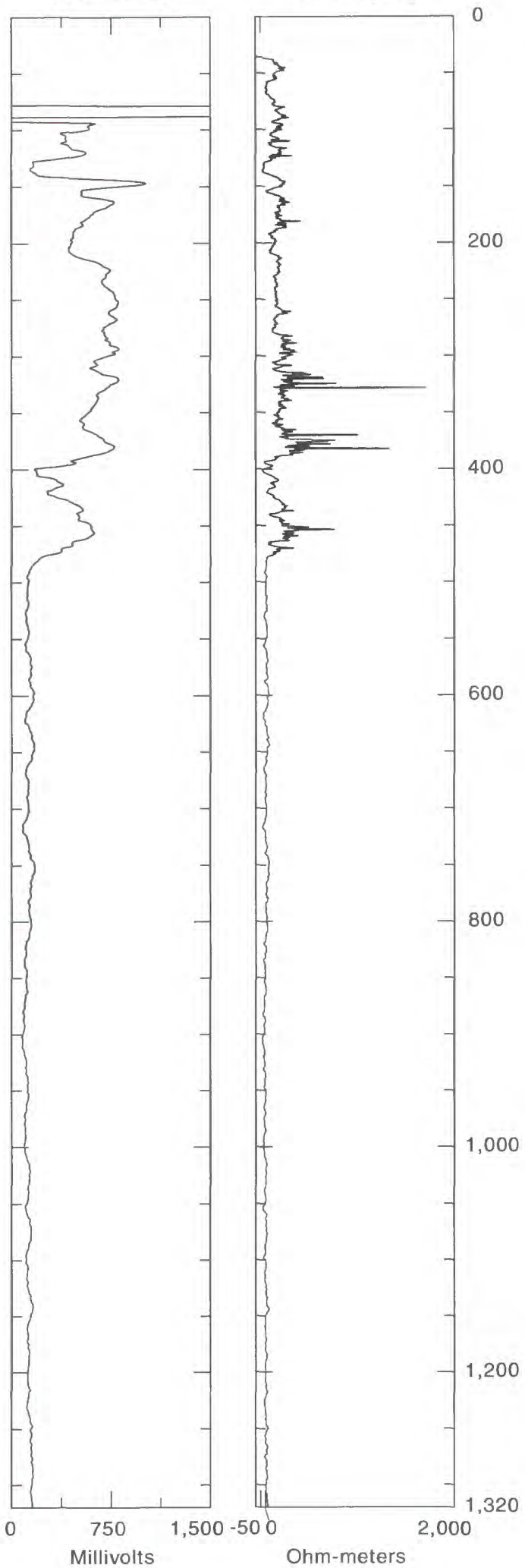

Lateral resistivity log

Figure 23K. Geophysical logs, piezometer completion, and generalized lithologic diagram for the Sandia Pueblo site (lithologic information from Connell, 1998). 


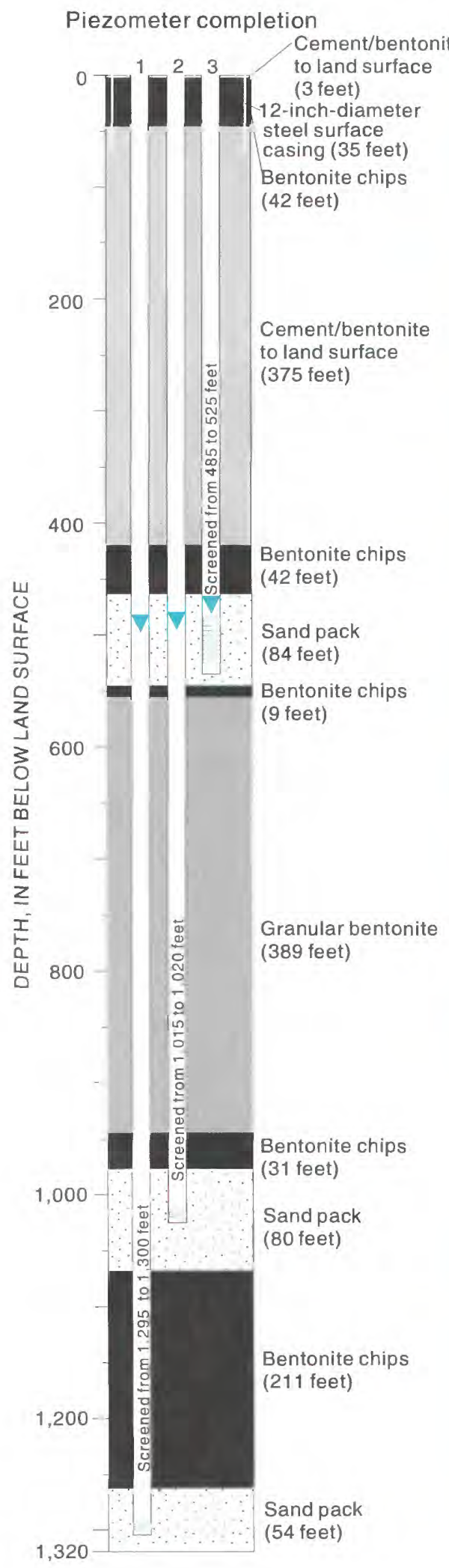

Lithology
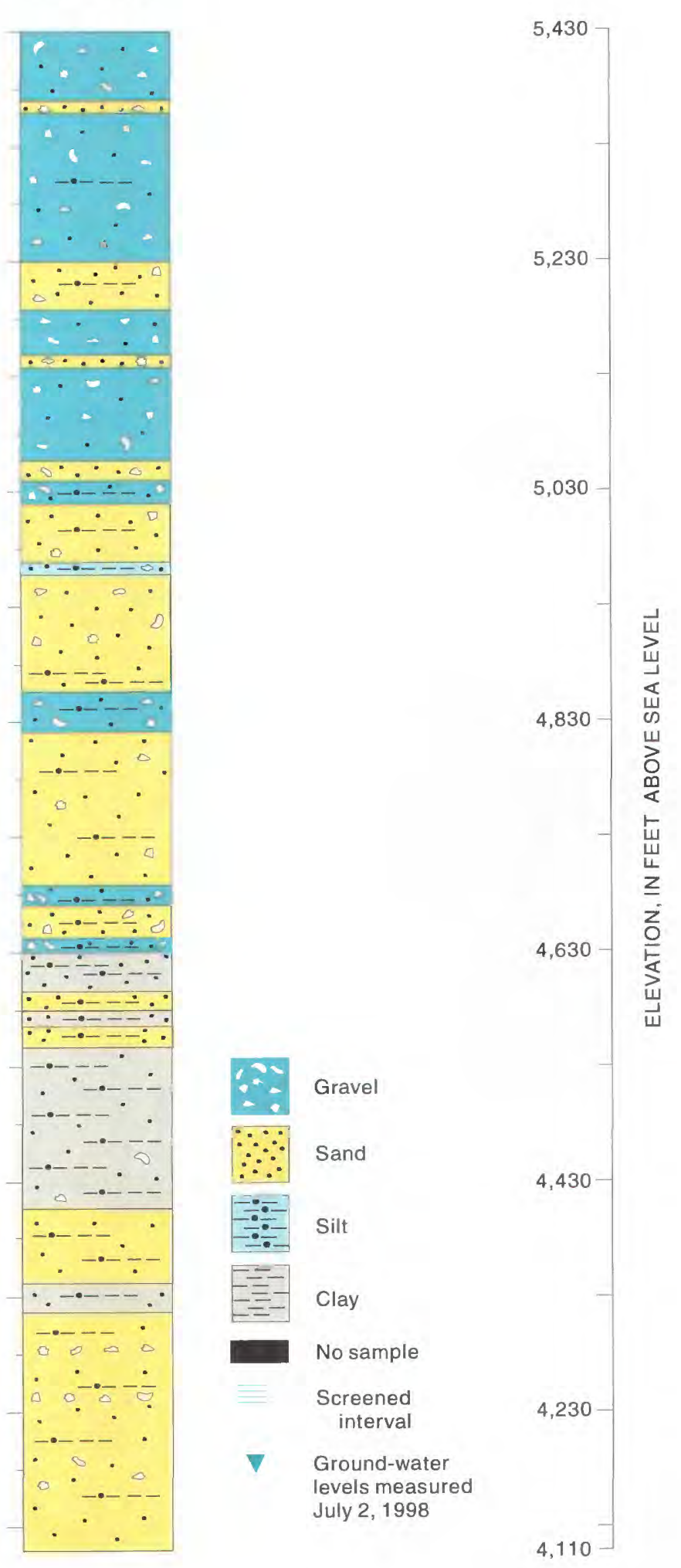

Figure 23K. Geophysical logs, piezometer completion, and generalized lithologic diagram for the Sandia Pueblo site (lithologic information from Connell, 1998)--Concluded. 


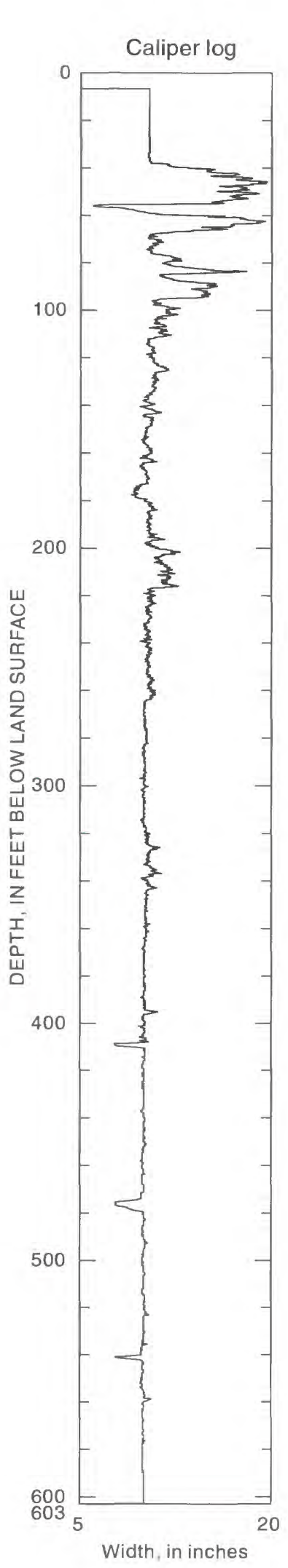

Electrical-

conductivity log

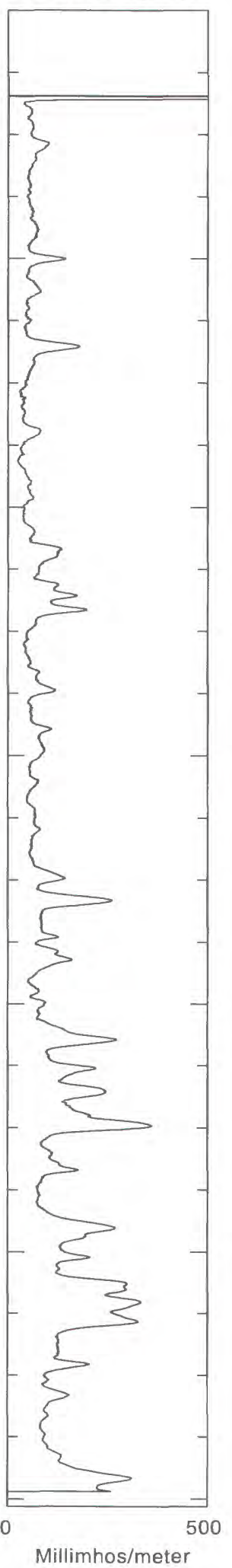

Gamma log

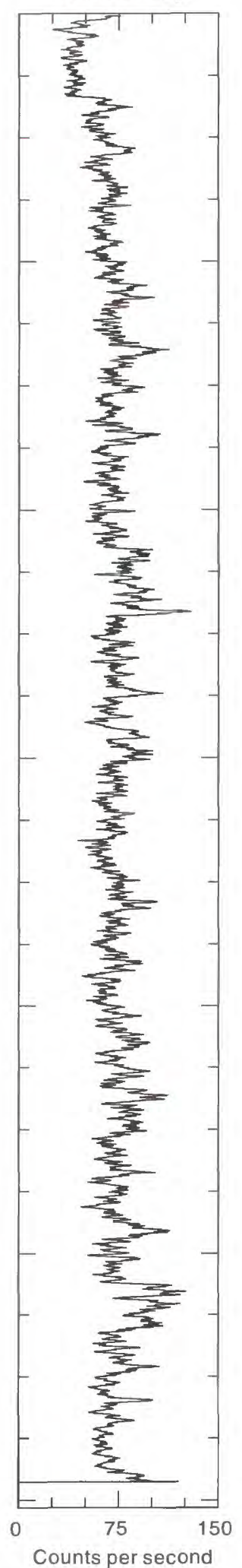

Single-point

resistivity log

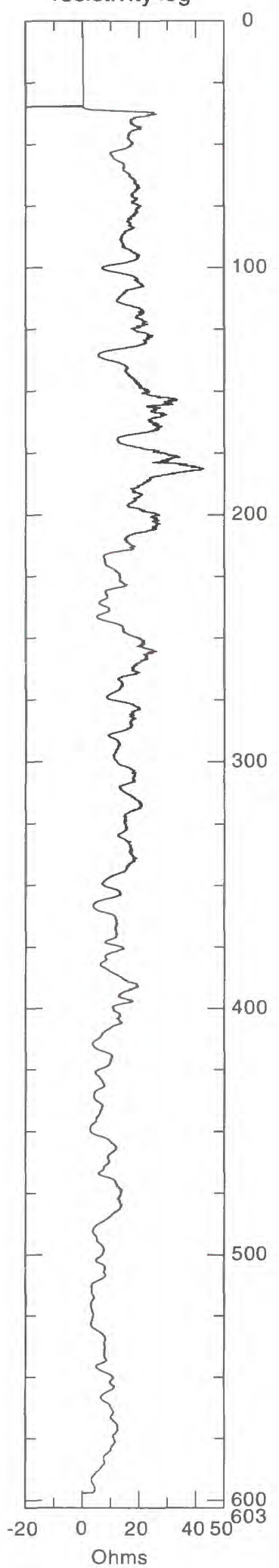

Figure 23L. Geophysical logs, piezometer completion, and generalized lithologic diagram for the Rio Bravo Park site (lithologic information from Jackson-Paul and Connell, 2001a). 

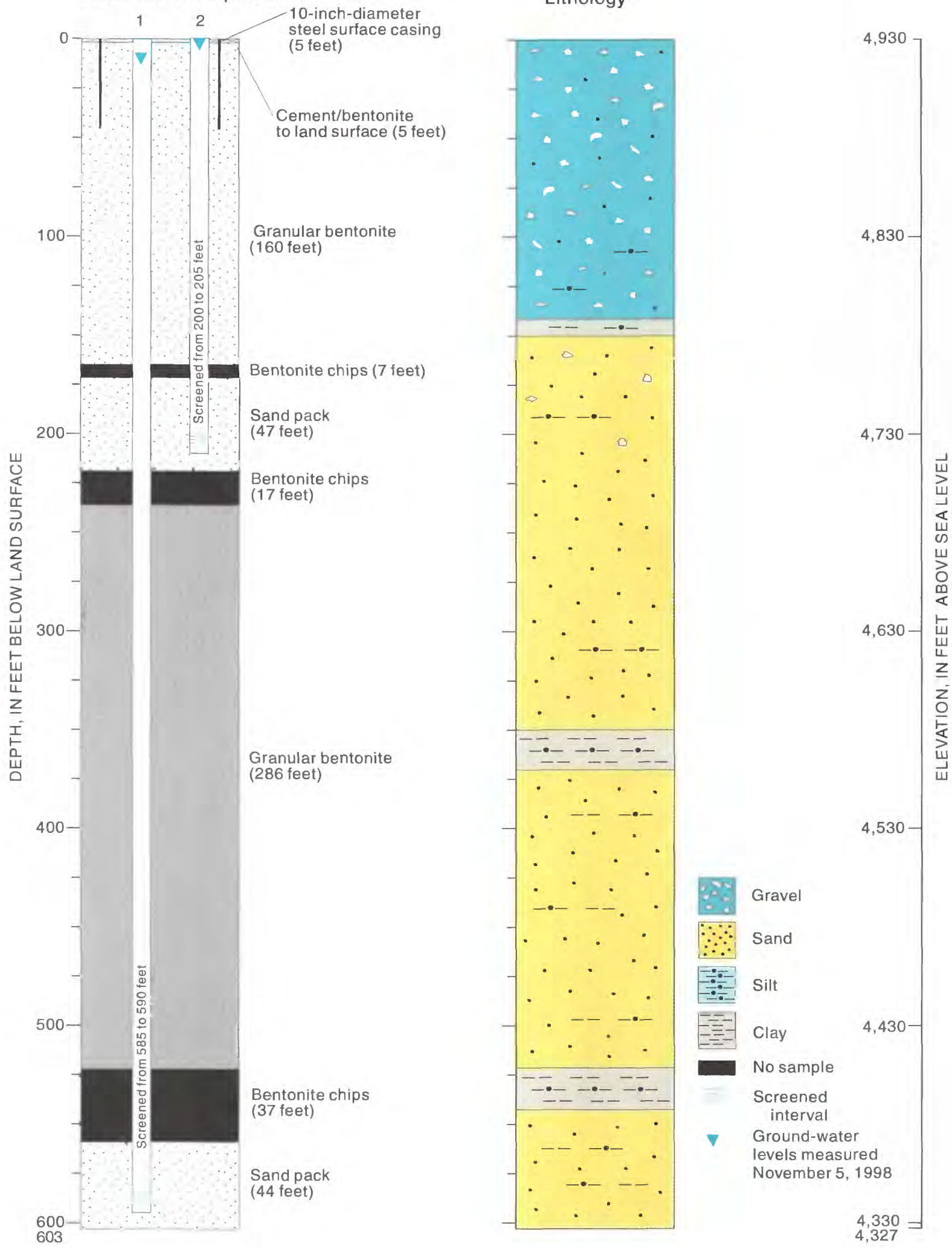

Figure 23L. Geophysical logs, piezometer completion, and generalized lithologic diagram for the Rio Bravo Park site (lithologic information from Jackson-Paul and Connell, 2001a)-Concluded. 


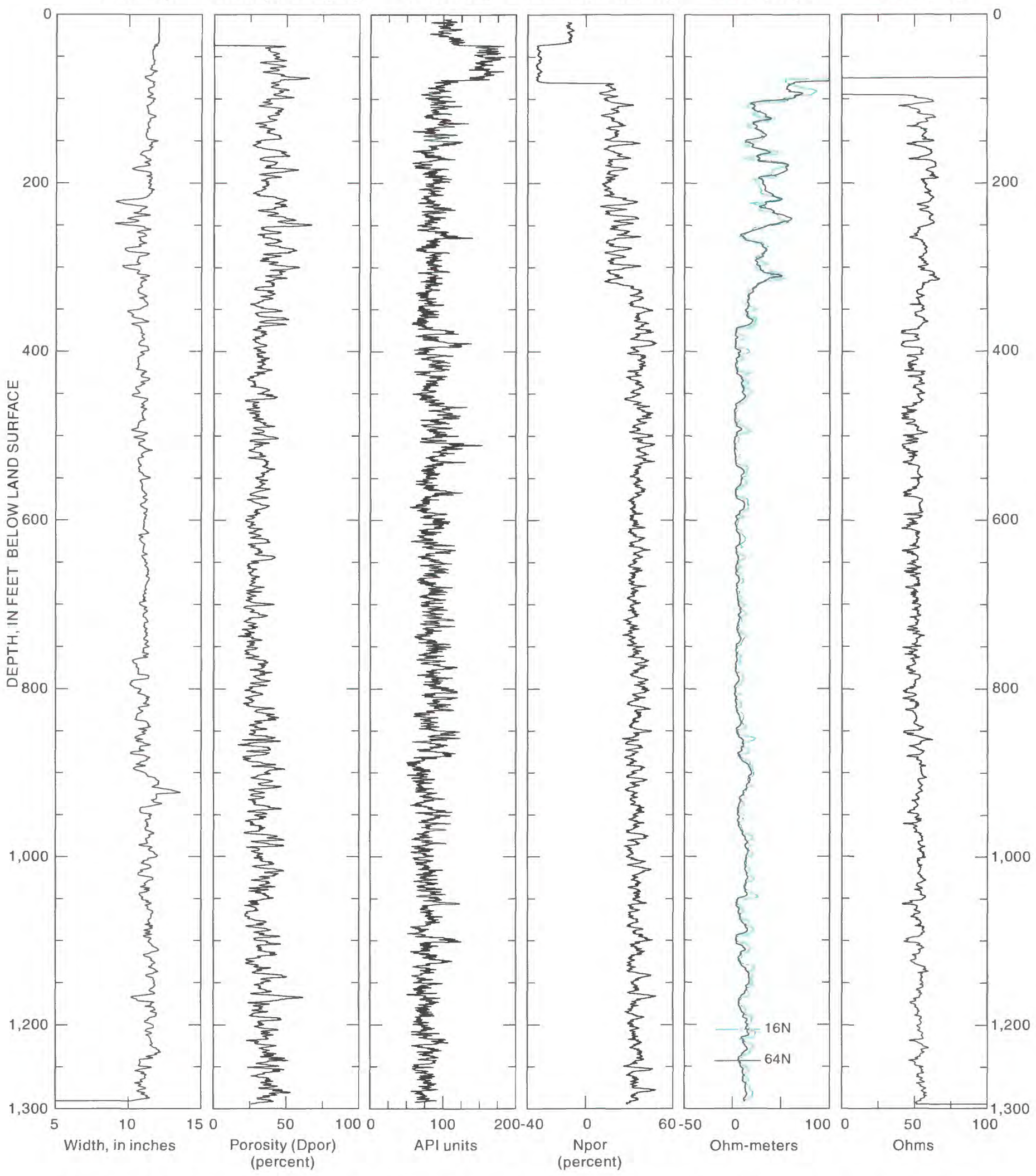

Figure 23M. Geophysical logs, piezometer completion, and generalized lithologic diagram for the Westgate Heights Park site (lithologic information from Jackson-Paul and Connell, 2001d). 


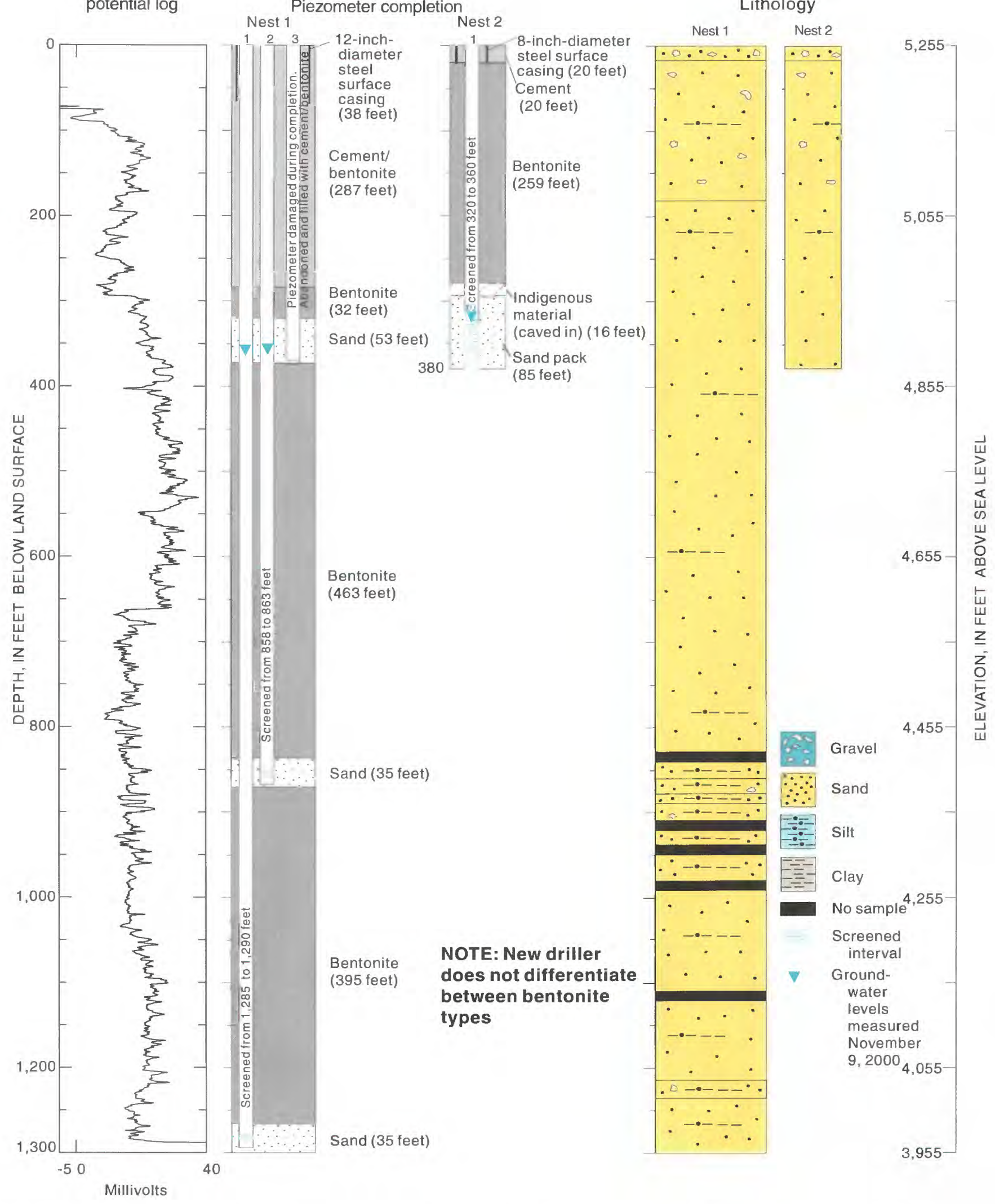

Figure 23M. Geophysical logs, piezometer completion, and generalized lithologic diagram for the Westgate Heights Park site (lithologic information from Jackson-Paul and Connell, 2001d)--Concluded. 
16 -inch (16N)

and 64 -inch $(64 \mathrm{~N})$

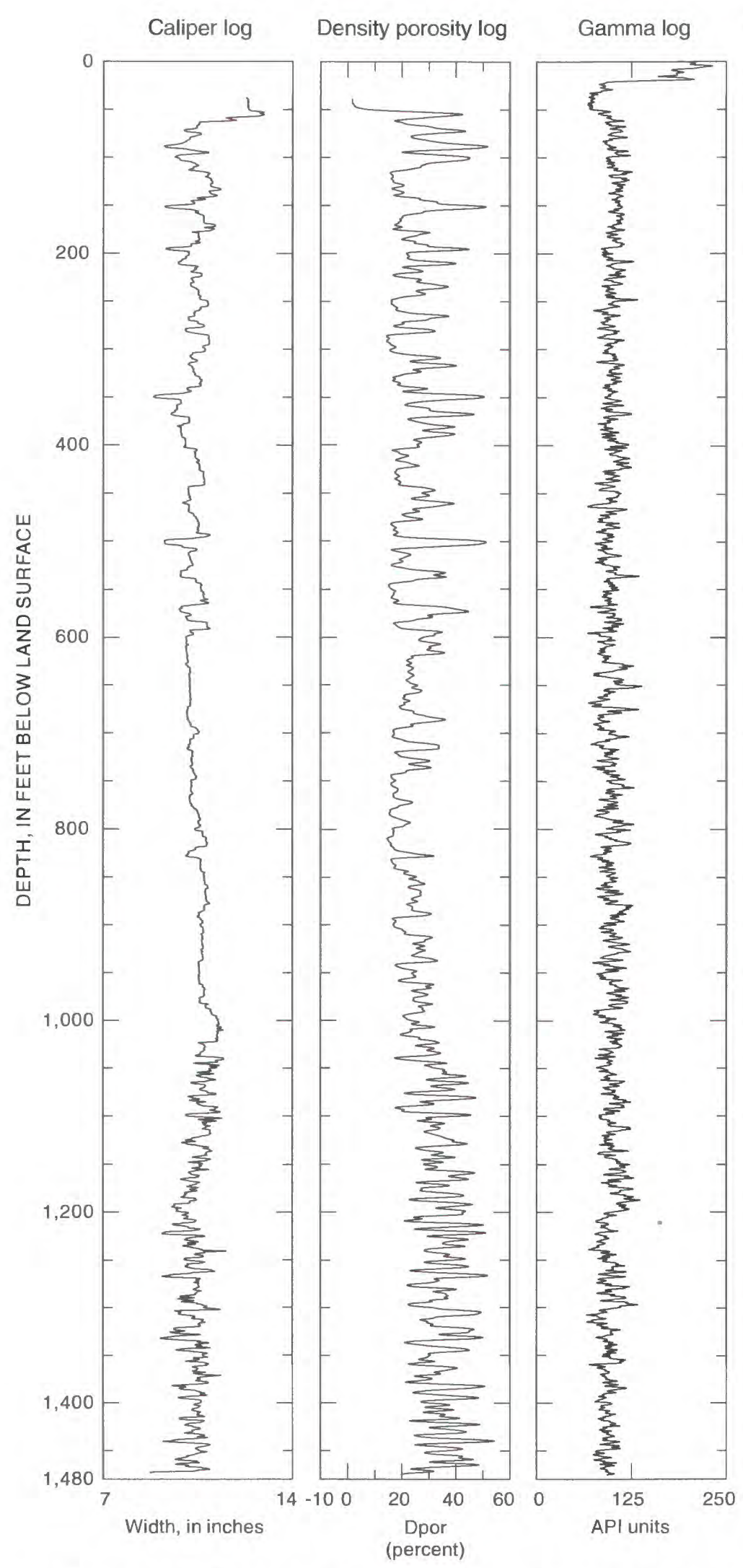

Neutron porosity log

resistivity logs

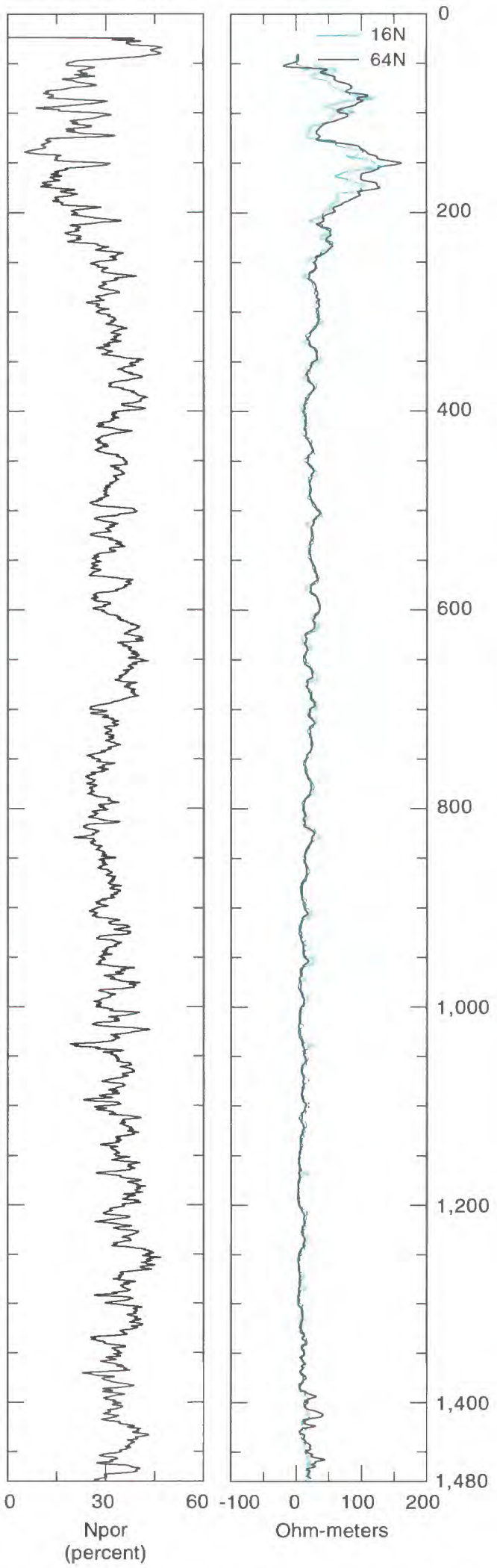

Figure 23N. Geophysical logs, piezometer completion, and generalized lithologic diagram for the Niese Drive site (lithologic information from Jackson-Paul and Connell, 2001b). 


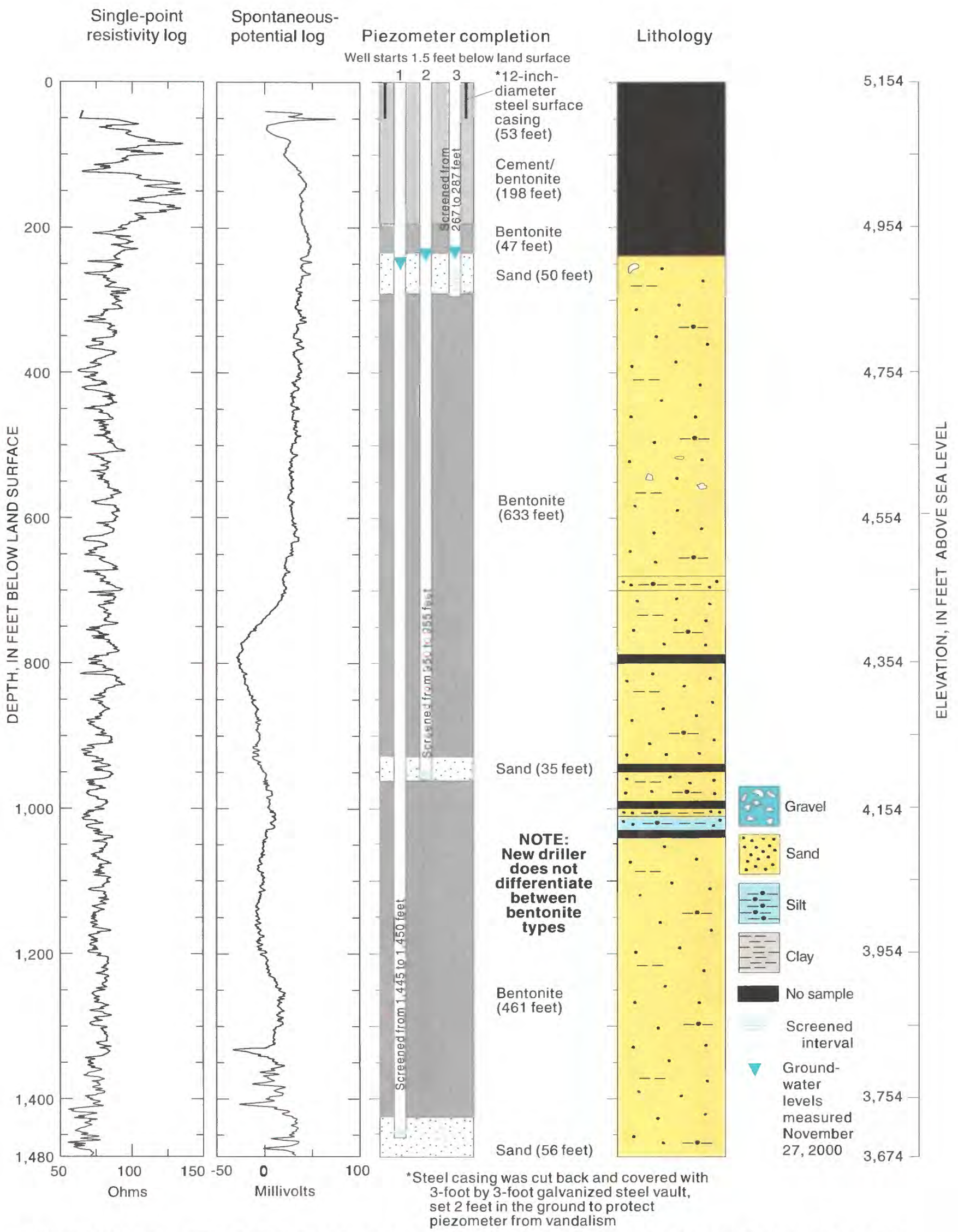

Figure 23N. Geophysical logs, piezometer completion, and generalized lithologic diagram for the Niese Drive site (lithologic information from Jackson-Paul and Connell, 2001b)-Concluded. 


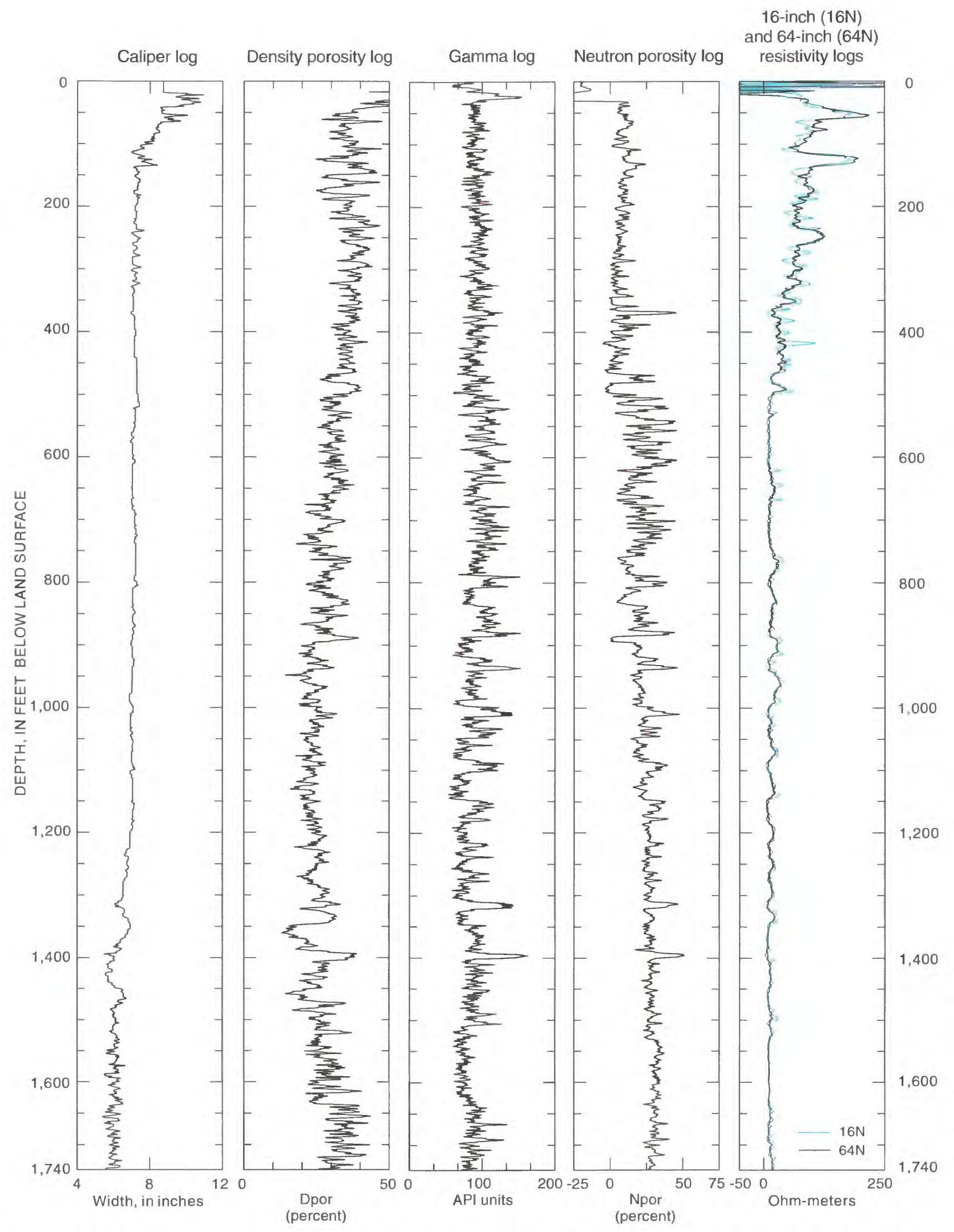

Figure 230. Geophysical logs, piezometer completion, and generalized lithologic diagram for the Paradise Boulevard site (lithologic information from Jackson-Paul and others, 2001c). 


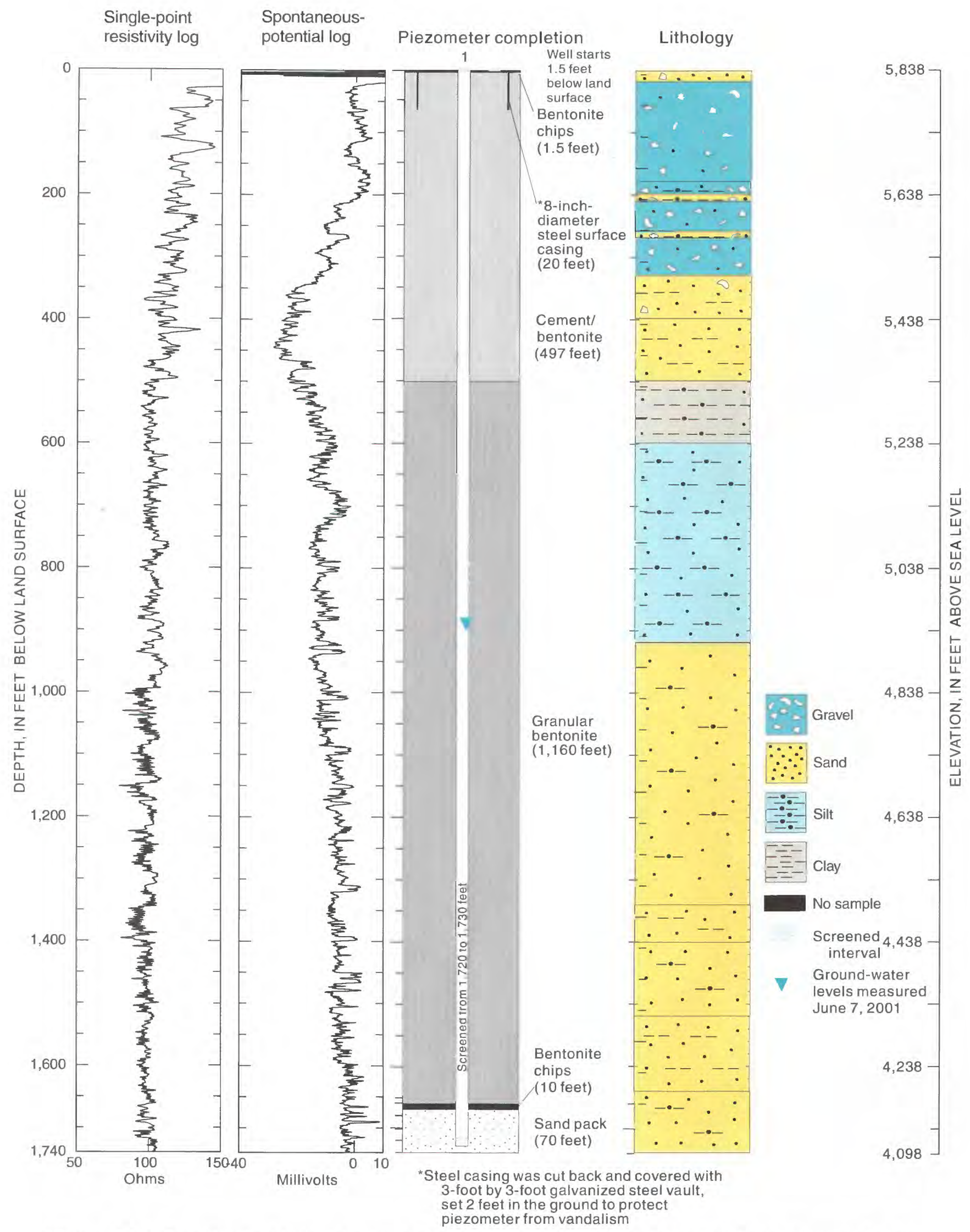

Figure 230. Geophysical logs, piezometer completion, and generalized lithologic diagram for the Paradise Boulevard site (lithologic information from Jackson-Paul and others, 2001c)--Concluded. 


U.S. Department of the Interior

U.S. Geological Survey, WRD

5338 Montgomery Blvd. NE, Suite 400

Albuquerque, NM 87109-1311

\section{BOOK RATE}

